Portland State University

PDXScholar

6-15-2020

\title{
Social Saints in the City: Race, Space, and Religion in Chicago Women's Settlement Work, 1890-1935
}

Johanna Katherine Murphy

Portland State University

Follow this and additional works at: https://pdxscholar.library.pdx.edu/open_access_etds

Part of the History Commons, Religion Commons, and the Social Work Commons Let us know how access to this document benefits you.

Recommended Citation

Murphy, Johanna Katherine, "Social Saints in the City: Race, Space, and Religion in Chicago Women's Settlement Work, 1890-1935" (2020). Dissertations and Theses. Paper 5559.

https://doi.org/10.15760/etd.7433

This Thesis is brought to you for free and open access. It has been accepted for inclusion in Dissertations and Theses by an authorized administrator of PDXScholar. Please contact us if we can make this document more accessible: pdxscholar@pdx.edu. 
Social Saints in the City: Race, Space, and Religion in Chicago Women's Settlement

Work, 1890-1935

by

Johanna Katherine Murphy

A thesis submitted in partial fulfillment of the requirements for the degree of

\author{
Master of Arts \\ in \\ History
}

Thesis Committee:

Patricia Schechter, Chair

David A. Horowitz

Katrine Barber

Jennifer Ruth

Portland State University

2020 


\begin{abstract}
Many scholars on the settlement movement have mentioned Hull-House's interactions with the Catholic Church and/or the surrounding immigrant communities, but have failed to fully examine the dynamic between Hull-House women, Catholic laywomen who took up settlement work, and the various Catholic immigrant groups of Chicago. This research seeks to place these relationships within the context of spacemeaning physical space in the neighborhood, access to spaces, and space as influence. This lens acts as a thread connecting the tangled and fluctuating dynamics of race, ethnicity, religion, and gender surrounding the settlement house movement.
\end{abstract}

Hull-House residents and Catholic laywomen contended for influence among immigrant communities as they sought to carve out space for themselves in their respective spheres. Hull-House women positioned themselves as experts pushing for government intervention in ways that would elevate women's involvement and expand their rights in the public sphere. Catholic settlement workers on the other hand operated within a kind of third space between the male clergy and the orders of religious sisters. They had to work harder for visibility and funding within the Church hierarchy by establishing that their work was a new contribution, but that they were not challenging prescribed roles for women within the Church. In the realm of settlement work these two groups of women found much common ground, but they clashed with each other on issues concerning motherhood, children, and the home - traditionally areas of women's influence. Meanwhile the Catholic immigrant groups of Chicago cared little for the division between the Church and the Hull-House, organizing their communities at times 
around the churches and the settlements according to their own needs and priorities. But not all groups had equal access to the settlements. The way in which settlements regulated access to their space marginalized their Mexican and African American neighbors while helping to solidify and define the boundaries of whiteness. 


\section{Acknowledgements}

I would like to thank the faculty of the History department of Portland State University for the opportunities and support they have given me over the past three years, and for their financial support through the Fulton-Dodds Graduate Fellowship. I am especially indebted to my advisor, Dr. Patricia Schechter, who has offered encouragement and guidance through several versions and drafts of this thesis. I am also grateful to Dr. David A. Horowitz, Dr. Katrine Barber, and Dr. Jennifer Ruth, for dedicating their time and energy to serving on this committee, even in the middle of strange and challenging times. Additionally, I could not have completed my archival research without the assistance of Erin Glasco and Kellee Warren at the University of Illinois at Chicago; Christine Colburn at the University of Chicago; and Phillip Runkel at Marquette University. Thank you also to the Special Collections and University Archives at the University of Illinois at Chicago for granting permission to use photographs from the Hull-House Collection. 
Table of Contents

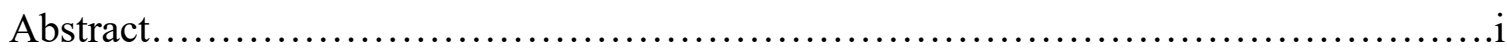

Acknowledgements...........................................................

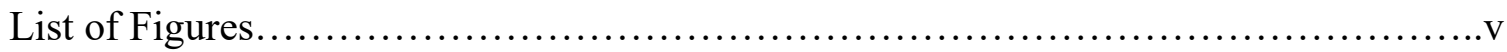

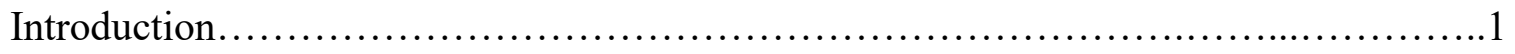

Chapter 1: Contextualizing Chicago: The Neighborhoods, the Churches, and the

Settlements............................................................... 23

Chapter 2: Contestation for Space and Influence..............................56

Chapter 3: Reinforcing the Color Line..................................... 99

Conclusion............................................................113

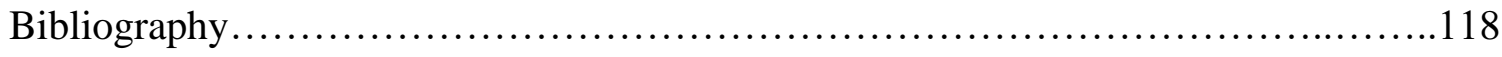




\section{List of Figures}

"At the Front Door of Hull-House" ...........................................vi

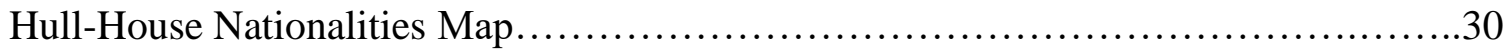

Churches and Social Settlements of the Near West Side.............................. 38

“A Clinic - Infant Welfare Society" ...........................................68 


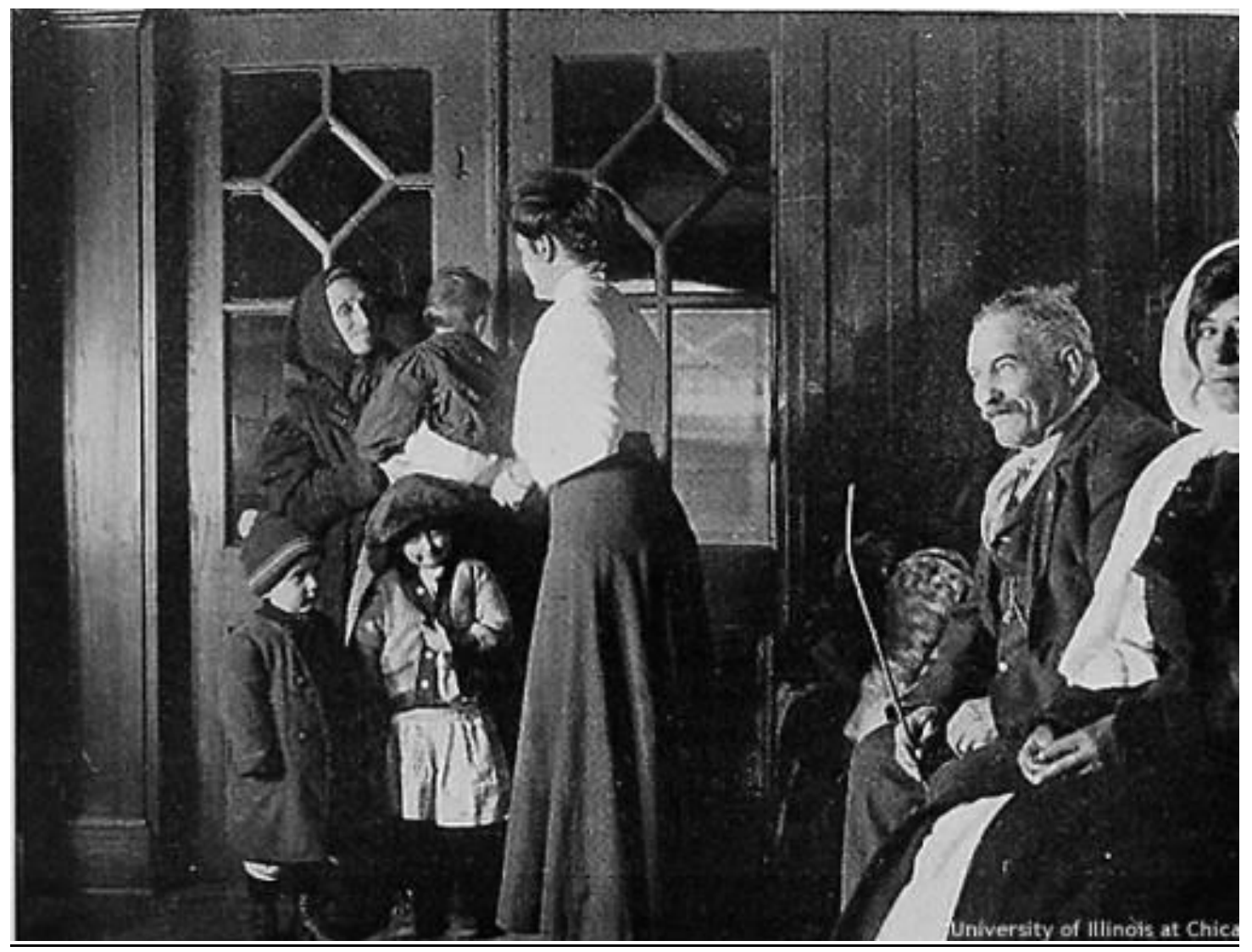

“At the Front Door of Hull-House (1913)." 436-5571, Hull-House yearbook photos, Special Collections and University Archives, University of Illinois at Chicago. Photograph reproduced with permission of University Archives. 
$\underline{\text { Introduction }}$

It was on the streets of Rome where the idea for the Hull-House began to take full form in the mind of a young Jane Addams. Though she originally conceived of the idea in England after visiting Toynbee Hall-the original English social settlement at OxfordAddams began to adapt the settlement idea to her own vision, influenced by American notions of democratic pluralism. As she toured the Vatican and the cathedrals of Rome with her friend Ellen Gates Starr, Addams reflected on "early hopes for the settlement that it should unite in the fellowship of the deed those of widely differing religious beliefs."1 Starr, who would embark on the settlement house project with her, also envisioned their work as a vehicle for achieving systemic changes that would benefit the underprivileged and the working class. She referred to this type of work as "social sainthood."2 Addams and Starr, in the tradition of the emerging Social Gospel, rejected religious dogma while drawing from the ethics and philosophies of "these early Roman Christians" who "received the Gospel message, a command to love all men, with a certain joyous simplicity." 3 These women would translate their ideals into the HullHouse, among many of the descendants of these "early Roman Christians"-Italian Catholic immigrants.

\footnotetext{
${ }^{1}$ Jane Addams, Twenty Years at Hull House with Autobiographical Notes (New York, NY: The MacMillan Company, 1911), 83.

2 Ellen Gates Starr, "Settlements and the Church's Duty" (1896), in On Art, Labor, and Religion, eds. Mary Jo Deegan and Ana-Maria Wahl (New Brunswick, NJ: Transaction Publishers, 2003), 155.

${ }^{3}$ Addams refers to this perspective as a "renaissance going on in Christianity" in Addams, Twenty Years, 122; see also Christopher H. Evans, The Social Gospel in American Religion: A History (New York, NY: New York University Press, 2017).
} 
Second-wave feminist scholars have granted Jane Addams and the Hull-House an enormous place in the history of social work and public welfare. ${ }^{4}$ Over time the House expanded to take up an entire city block on Halsted Street, acting as a gathering place for the community of Chicago's Near West Side, with thousands of people entering through its doors every week. ${ }^{5}$ The house was primarily funded by Addams's inheritance and the sponsorship of wealthy women, including Louise deKoven Bowen and Mary Rozet Smith. ${ }^{6}$ Hull-House played a remarkable range of roles in the neighborhood, from providing meeting places for local labor unions to teaching sewing classes to young girls. It boasted lectures, English and citizenship classes, a day nursery, a gym, public baths, a coffee house, a plethora of recreational classes and clubs, and more. Celebrations also brought in people from the surrounding neighborhood, like the weekly Italian reception

\footnotetext{
${ }^{4}$ See Mina Carson, Settlement Folk: Social Thought and the American Settlement Movement, 1885-1930 (Chicago, IL: The University of Chicago Press, 1990); Allen F. Davis, Spearheads for Reform: The Social Settlements and the Progressive Movement 1890-1914 (New York, NY: Oxford University Press, 1967); Mary Jo Deegan, Race, Hull-House, and the University of Chicago: A New Conscience Against Ancient Evils (Westport, CT: Praeger, 2002); Maureen A. Flanagan, Seeing with their Hearts: Chicago Women and the Vision of the Good City, 1871-1933 (Princeton, NJ: Princeton University Press, 2002); Robyn Muncy, Creating a Female Dominion in American Reform 18901935 (New York, NY: Oxford University Press, 1991); Eleanor J. Stebner, The Women of Hull House: A Study in Spirituality, Vocation, and Friendship (New York, NY: State University of New York Press, 1997); Judith Trolander, Professionalism and Social Change: From the Settlement House Movement to Neighborhood Centers 1886 to the Present (New York, NY: Columbia University Press, 1987).

5 The Hull-House Yearbook for 1906-1907 records 9,000 people coming to the house each week during the winter months, in Hull House Yearbook September 1906-1907, box 43, folder 434, Hull-House Collection, Special Collections and University Archives, University of Illinois at Chicago.

${ }^{6}$ Kathryn Kish Sklar, "Who Funded Hull House?" in Lady Bountiful Revisited: Women, Philanthropy, and Power, ed. Kathleen D. McCarthy (New Brunswick, NJ: Rutgers University Press, 1990), 95-104.
} 
or the annual Christmas parties. ${ }^{7}$ Hull-House maintained a close relationship with the University of Chicago, and residents like Sophonisba Breckinridge were influential in the development of the University's School of Social Work. ${ }^{8}$ Inspired by Jane Addams's example, hundreds more settlement houses sprang up throughout the country in short order, as reformers followed the Hull-House model of moving into impoverished neighborhoods and dedicating their lives and resources to the community.

Within a few years the Guardian Angel Mission took up residence only a few blocks from Hull-House. Originally a large Sunday School association linked to Holy Guardian Angel Church, the Mission eventually evolved into another settlement house, the Madonna Center. Led by Mary Amberg, daughter of a well-connected Catholic family on the Near West Side, Madonna Center became one of the largest and most influential Catholic social settlements in the nation. Amberg felt that the Madonna Center's mission was "more sacred than the purely humanistic one" of the other social settlements. ${ }^{9}$ The Center taught and nurtured thousands of children, yet it is unlikely to show up in the records of the settlement house movement. Her Catholic faith and the centering of spirituality in her work marginalized her in a movement that increasingly defined itself as explicitly secular. Addams and her counterparts became the normative model of settlement work, promoting a pluralistic vision of community that self-

\footnotetext{
${ }^{7}$ Mentioned in Hull-House Yearbook 1913, box 43, folder 436, Hull-House Collection. ${ }^{8}$ For more on connection between Hull-House residents and University of Chicago see Deegan, Race.

${ }^{9}$ Mary Agnes Amberg, Madonna Center: Pioneer Catholic Settlement (Chicago, IL: Loyola University Press, 1976), 83-84.
} 
consciously rejected alignment with any one creed. ${ }^{10}$ Meanwhile, faith-based workers who looked askance at this secular humanist model decided that, with the backing of the Church, they could perform the work more effectively.

\section{Reexamining the Competition Narrative}

A common thread throughout the scholarship on the settlement house movement is the suspicion the Catholic Church felt towards the reach of the settlements, especially the large, influential ones like Hull-House. This competition narrative positions HullHouse as the normative institution against which the Catholic Church competed by adapting its strategies and producing its own settlement houses. According to some historians, this was an inadequate response in that religious institutions never became part of the mainstream movement, and Catholic settlement houses remained on the margins of the Church's outreach patterns. ${ }^{11}$ The National Federation of Settlements, formed in 1911, defined membership as a settlement house around a specifically secular and

\footnotetext{
${ }^{10}$ Graham Taylor of Chicago Commons, despite being a pastor, still believed the settlement house couldn't show preference to any religion or denomination without losing its claim to relate to the community on "common ground" (Stebner, Women, 41); See also "The Church and the Social Problem", September 25, 1901, Jane Addams Papers, https://digital.janeaddams.ramapo.edu/items/show/6864; "The Reaction of Modern Life Upon Religious Education,” February 11, 1910, Jane Addams Papers, https://digital.janeaddams.ramapo.edu/items/show/4957; Clippings 1895-1899, box 48, folder 509, Hull-House Collection; National Federation of Settlements 1932, box 55, folder 670, Hull-House Collection.

${ }^{11}$ Richard M. Linkh, American Catholicism and European Immigrants, 1900-1924 (Staten Island, NY: Center for Migration Studies, 1975), 50-53; Dorothy M. Brown and Elizabeth McKeown, The Poor Belong to Us: Catholic Charities and American Welfare (Cambridge, MA: Harvard University Press, 1997), 67.
} 
pluralistic vision. ${ }^{12}$ This further centered early historians' depictions of the settlement movement as secular, and the Catholic settlements as defensive and reactionary.

Authors tend to stress Catholic leaders' perception of the settlements as covert Protestant organizations who were seducing unwitting Catholic immigrants away from the Church. Aaron Abell in American Catholicism and Social Action (1960) writes that Catholics embraced settlement work to keep immigrants, especially Italians, from being led away by either Protestantism or socialism, but that the majority of Catholics didn't grasp the "meanings and possibilities of the social settlement idea."13 Richard Linkh, in American Catholicism and European Immigrants (1975) also says that it was the "belief that Protestants were making successful converts of Catholics that finally led Catholics to become involved in the settlement movement."14 Charles Shanabruch's 1981 book Chicago's Catholics similarly claims that "the rise of Catholic settlement work can be explained only in relation to Catholic perceptions of secular and religious settlements that spring up in Chicago. The contrast between them was remarkable." ${ }^{15}$ He describes the Hull-House as focused on material reforms and social work while Catholic settlements were focused on spiritual issues over social ones. Eleanor Stebner, in The Women of Hull House (1997) agrees that Catholic women in Chicago opened settlement houses "as a

${ }^{12}$ See Robert A. Woods and Albert J. Kennedy, Handbook of Settlements (New York, NY: The Russell Sage Foundation, 1911), v-vi; National Federation of Settlements 1932, box 55, folder 670, Hull-House Collection.

${ }^{13}$ Aaron I. Abell, American Catholicism and Social Action: A Search for Social Justice 1865-1950 (Garden City, NY: Hanover House, 1960), 156-163.

${ }^{14}$ Linkh, American Catholicism, 52.

${ }^{15}$ Charles Shanabruch, Chicago's Catholics: The Evolution of an American Identity (Notre Dame, IN: University of Notre Dame Press, 1981), 131. 
way to offset the predominantly Protestant involvement in social settlements." ${ }^{\prime 16}$ Finally, Deirdre M. Moloney’s American Catholic Lay Groups and Transatlantic Social Reform in the Progressive Era (2002) discusses Catholic settlements as a "defensive measure" against fears of Protestant proselytizing. ${ }^{17}$

Speeches and writings by both Catholic leaders and laywomen in this period provide evidence to support this sense of suspicion. Addresses of the First and Second American Catholic Missionary Congresses discussed the danger settlement houses posed to immigrants who were not adequately shepherded by the Church. Reverend James Curry in 1908 gave an entire speech condemning social settlements and accusing them of exerting an anti-Catholic influence upon immigrants. He exhorted wealthy Catholics to take up similar work, demanding to know what they were doing to counter the influence of "our rich Protestant friends." 18 Reverend Muldoon also raised the alarm about the presence of the settlements, "located in centers where Catholic immigrants congregate. They have not seemed satisfied to minister to the Protestant immigrant, but have challenged the right of the Catholic Church to her own, and this challenge she must accept with all its burdens, difficulties, expenditure, and sacrifice." ${ }^{19}$ Mary Amberg's

\footnotetext{
${ }^{16}$ Stebner, Women, 37.

${ }^{17}$ Deirdre M. Moloney, American Catholic Lay Groups and Transatlantic Social Reform in the Progressive Era (Chapel Hill, NC: University of North Carolina, 2002), 121-141. ${ }^{18}$ Full quote: "Every possible field of energy in charity is being worked by our rich Protestant friends, and foundations to meet every form of distress have been established by them. What are our rich Catholics doing?" In James B. Curry, "Settlement Work," in The First American Catholic Missionary Congress, ed. Francis C. Kelley (Chicago, IL: J.S. Hyland and Company, 1908), 165.

${ }^{19}$ P.J. Muldoon, "Immigration to and the Immigrants in the United States," in Official Report of the Second American Catholic Missionary Congress (Chicago, IL: J.S. Hyland \& Co., 1914), 143.
} 
perspective, as a female settlement worker heading the nearby Madonna Center, demonstrated a bit more complexity. She viewed settlement leaders like Jane Addams, Graham Taylor, and Harriet Vittum as friends and "pioneers" in working to aid immigrants-yet she simultaneously saw them as competition and "dangerous" to Catholic immigrants. ${ }^{20}$ Amberg framed the influence of Hull-House among Chicago's Italians as a challenge that she and her friends at Guardian Angel were duty-bound to meet by "entering the lists and competing, through a spiritualized social work in this struggle."21

However, this narrative leaves several blindspots. First, many of these accounts have failed to incorporate the perspective of immigrants as people with agency, rather than a passive constituency for whose loyalty the Church and social settlements contended. ${ }^{22}$ Undoubtedly this is partially due to the scarcity of immigrant voices in the

${ }^{20}$ Amberg, Madonna Center, 2, 39; see also "Catholic Social Service," Catholic Journal, Dec 14, 1917; Teresa R. O'Donohue, “The Association of Catholic Charities," Catholic Charities Review 2, no. 7 (September 1918): 217; “A Religious Community of Professional Settlement Workers," Catholic Charities Review 5, no. 4 (April 1921): 124; R.A. McEachen, "Our Five Million Immigrants," in The First American Catholic Missionary Congress, ed. Francis C. Kelley (Chicago, IL: J.S. Hyland and Company, 1908), 274-275; Andrew Shipman, "Address," in Official Report of the Second American Catholic Missionary Congress (Chicago, IL: J.S. Hyland \& Co., 1914), 167; Abell, American Catholicism, 161-166; Linkh, American Catholicism and European Immigrants, 38-40.

${ }^{21}$ Christ-Child Society of Chicago 1915-1916, Madonna Center Records, series 1, box 2, folder 7, Mary Agnes Amberg Papers, Special Collections and University Archives, Marquette University.

${ }^{22}$ Linkh discusses Catholic attempts to work with "missionary" groups of immigrants (Linkh, American Catholicism, 51-55); Trolander also discusses the presence or absence of immigrants at Hull-House in terms of the house's contentions with the Catholic Church (Trolander, Professionalism, 19); Lissak says Hull-House residents treated immigrants as a "helpless mass" and highlights the weaknesses in their approach but pays little attention to the choices immigrant families made (Rivka Shpak Lissak, Pluralism and Progressives: Hull House and the New Immigrants, 1890-1919 (Chicago, IL: University of Chicago Press, 1989), 37); Muncy focuses on how reform women used 
record, making it much harder to represent their perspectives. Yet enough samplings exist to demonstrate that Chicago immigrants utilized both Catholic and secular institutions according to their preferences and needs, sometimes in accordance and sometimes in defiance of advice from community leaders. The concept of agency should not be overstated to the point where it erases the power dynamic between impoverished immigrants and American-born reformers with resources, but neither should it be denied in the narrative. ${ }^{23}$

Second, most scholarly discussions on the competition between the Church and Hull-House have focused on the priorities of Church leaders, minimizing the goals and perspectives of laywomen who actually conducted the work of Catholic social settlements. These women tended to focus on the spiritual and material welfare of women and children in the community. As such, certain clashes between secular and religious female reformers have remained mostly unexamined, such as the debates over birth control and children's schooling.

Third, the racial dynamic of the settlement movement is rarely developed, because most scholarship on the settlement movement ends at the World War I period, confining the focus to European immigrants and skipping the Great Migration. 1916 marked the beginning of significant Mexican and African American migration to the

their position of authority over immigrant women to create a "dominion" for themselves (Muncy, Creating, 30-31).

${ }^{23}$ Sources include Hull-House Oral History Collection, Special Collections and University Archives, University of Illinois at Chicago, and Hilda Satt Polachek, I Came a Stranger: The Story of a Hull-House Girl, ed. Dena J. Polachek Epstein (Urbana, IL: University of Illinois Press, 1989). 
Near West Side, displacing some of the European immigrant groups that had been the dominant presence in the settlements until that point. Following Elisabeth Lasch-Quinn's work, this study extends the timeframe through the interwar years to demonstrate how settlement workers' missions of unity and breaking down barriers were challenged when faced with new, nonwhite neighbors and racial tensions. ${ }^{24}$

In essence, many scholars on the settlement movement have mentioned HullHouse's interactions with the Catholic Church and/or the surrounding immigrant communities, but have failed to fully examine the dynamic between Hull-House women, Catholic laywomen who took up settlement work, and the various Catholic immigrant groups of Chicago. This research seeks to place these relationships within the context of space - meaning physical space in the neighborhood, access to spaces, and space as influence. This lens acts as a thread connecting the tangled and fluctuating dynamics of race, ethnicity, religion, and gender surrounding the settlement house movement.

Boundaries within the physical environment of Chicago were produced and enforced by both tangible borders (i.e. parish districts, restrictive housing covenants) and social relations Gendered expectations limited women's mobility in the urban space, and conflicts between different ethnic and national groups laid a network of boundaries over the physical plane of the neighborhoods. Thus geographic space could be both material and socially constructed, fixed and shifting.

\footnotetext{
${ }^{24}$ Lasch-Quinn discusses the importance of extending scholarship on the settlement houses past World War I in Elisabeth Lasch-Quinn, Black Neighbors: Race and the Limits of reform in the American Settlement House Movement, 1890-1945 (Chapel Hill, NC: University of North Carolina Press, 1993), 3.
} 
But this project also deals with space as a discursive project, as reformers sought to carve out a place for themselves within the socio-political fabric of the Progressive Era. In doing so they challenged constructed boundaries of religion, class, and gender, as well as power and influence. Women's settlement work created a third space in urban reform, which required "inventing creative ways to cross real and perceived 'borders.", 25 Race, Space, and Influence

Settlement houses placed themselves in the neighborhoods of poor, foreign-born communities because it positioned them as neighbors, distinguishing themselves from the styles of charity and philanthropy that had previously defined women's public work. ${ }^{26}$ The way settlement residents limited access to space between different immigrant groups reinforced distinctions of race and whiteness. These same racial perceptions influenced how immigrant communities organized themselves in relation to each other in the landscape of the city. Finally, unstable constructs of race and nationalism influenced when and how different immigrant groups chose to relate to Hull-House and settlement houses in general. ${ }^{27}$

${ }^{25}$ Paul Routledge, "The Third Space as Critical Engagement," Antipode 28, no. 4 (October 1996), 406.

${ }^{26}$ Hull-House workers would "form acquaintances and friendships as naturally as possible with the residents of the neighborhood," quoted in "Hull House and its Neighbors," May 7, 1904, Jane Addams Papers, https://digital.janeaddams.ramapo.edu/items/show/3619; For Addams's distinction between the settlement method and philanthropy see Addams, Twenty Years, 119-126; See also Samuel A. Barnett, "Education by Permeation" (1906), in Readings in the Development of Settlement Work, ed. Lorene M. Pacey (New York, NY: Association Press, 1950), 79-82.

${ }^{27}$ See Humbert S. Nelli, Italians in Chicago 1880-1930: A Study in Ethnic Mobility (New York, NY: Oxford University Press, 1970); Victor Greene, “'Becoming American:' The 
Hull-House residents and Catholic laywomen contended for influence among immigrant communities as they sought to carve out space for themselves in their respective spheres. Hull-House women positioned themselves as experts pushing for government intervention in ways that would elevate women's involvement and expand their rights in the public sphere. Catholic settlement workers on the other hand operated within a kind of third space between the male clergy and the orders of religious sisters. They had to work harder for visibility and funding within the Church hierarchy by establishing that their work was a new contribution, but that they were not challenging prescribed roles for women within the Church. In the realm of settlement work these two groups of women found much common ground, but they clashed with each other on issues concerning motherhood, children, and the home-traditionally areas of women's influence. Meanwhile the Catholic immigrant groups of Chicago cared little for the division between the Church and the Hull-House, organizing their communities at times

Role of Ethnic Leaders-Swedes, Poles, Italians, and Jews," in The Ethnic Frontier: Essays in the History of Group Survival in Chicago and the Midwest, ed. Melvin G. Holli and Peter d'A Jones (Grand Rapids, MI: William B. Eerdman's Publishing Company, 1977); Lisabeth Cohen, Making a New Deal: Industrial Workers in Chicago, 1919-1939 (New York, NY: Cambridge University Press, 1990); John T. McGreevy, Parish Boundaries: The Catholic Encounter with Race in the Twentieth-Century Urban North (Chicago, IL: University of Chicago Press, 1996); Katrina Irving, Immigrant Mothers: Narratives of Race and Maternity, 1890-1925 (Champaign, IL: University of Illinois Press, 2000); Thomas A. Guglielmo, White on Arrival: Italians, Race, Color, and Power in Chicago, 1890-1945 (New York, NY: Oxford University Press, 2003); Gabriela F. Arredondo, Mexican Chicago: Race, Identity, and Nation, 1916-39 (Urbana, IL: University of Illinois Press, 2008); Cheryl R. Ganz and Margaret Strobel, eds., Pots of Promise: Mexicans and Pottery at Hull House, 1920-1940 (Chicago, IL: University of Illinois Press, 2004); Michael Innis-Jiménez, Steel Barrio: The Great Mexican Migration to South Chicago, 1915-1940 (New York, NY: New York University Press, 2013); Linkh, American Catholicism; Lissak, Pluralism and Progressives; Lasch-Quinn, Black Neighbors. 
around the churches and the settlements according to their own needs and priorities. But not all groups had equal access to the settlements. The way in which settlements regulated access to their space marginalized their Mexican and African American neighbors while helping to solidify and define the boundaries of whiteness.

\section{Structure of the Thesis}

For this project, I have chosen to focus on primarily Catholic immigrant groups on the Near West Side, particularly Irish, Italian, Polish, and Mexican communities, as they were the largest Catholic groups. Smaller Catholic communities also existed among smaller immigrant groups including Bohemians, Czechs, Slovaks, and Lithuanians. Additionally, the Jewish community had a significant presence at Hull-House. ${ }^{28}$ But for the sake of containing the project and analyzing the Catholic/secular dynamic, this project will reserve its focus to the city's major Catholic immigrant groups. African Americans have also been included because a percentage were Catholic, and because their presence is vital to understanding the dynamics of space and racialization in Chicago.

The sources I've drawn from include archival records from the Hull-House Collection, the Hull-House Oral History Collection, the digitized Jane Addams Papers, the Adena Miller Rich Papers, and the Madonna Center Records. ${ }^{29}$ Also valuable have

\footnotetext{
${ }^{28}$ For works that discuss the Jewish community at Hull House see Lissak, Pluralism and Progressives, and Polachek, I Came a Stranger.

${ }^{29}$ These are the primary collections but some documents from the Sophonisba P. Breckinridge Papers, Special Collections Research Center, University of Chicago Library, and the Grace and Edith Abbott Papers, Special Collections and Research Center, University of Chicago Library, have been included as well.
} 
been memoirs including Jane Addams's Twenty Years at Hull-House, Mary Amberg's Madonna Center, and Hilda Satt Polachek's I Came a Stranger: The Story of a Hull House Girl. Additionally, I draw on studies by contemporary sociologists associated with the Hull-House, like Hull-House Maps and Papers, New Homes for Old by Sophonisba Breckinridge, and the Handbook of Settlements by Robert A. Woods and Albert J. Kennedy. Valuable insights into the Catholic perspective include Rerum Novarum, proceedings from the First and Second American Catholic Missionary Congresses, and the Addresses and Papers from the World's Congress of Religions held in Chicago in 1893. Finally, I've drawn from articles in the Catholic Charities Review, The Catholic Journal, and The Chicago Tribune.

The first chapter seeks to spatialize the settlement houses, churches, and immigrant enclaves of Chicago's Near West Side in the Progressive Era and interwar period. It will introduce how themes of nationalism, race, ethnicity, and religion interacted with each other in these spaces. The second chapter delves into the ways HullHouse women and Catholic settlement women sought to build their own reform spaces and the issues of motherhood and child welfare that divided them. It also examines how immigrant communities viewed this division and how they positioned themselves in relation to the settlements and the Catholic institutions. Chapter three shows how HullHouse differentiated access to its facilities and programs in ways that reinforced emerging concepts of racial divisions and re-centered white immigrants as the norm in the settlement house environment.

\section{Historiography}


One of the challenges of this project has been bringing several strands of historical research-on social settlements, the urban immigrant experience, the Catholic Church in America, race and ethnicity, and gender dynamics-together into a coherent narrative. Though these subjects are all interwoven, they don't necessarily fit together in ways that lead to easy categorization. As such, the complex nature of these subjects can reproduce or perpetuate blindspots in the historiography, as many authors position their work specifically within the veins of religious history, immigrant history, or women's history.

Early works on Hull-House positioned the settlement houses as distinctly secular institutions, providing cultural leaders where none had previously existed. Allen Davis's Spearheads for Reform (1967) was one of the first major texts on the settlement movement. Davis follows the claims of settlement workers in drawing a firm line between social settlements and charity-saying the former led to reform whereas the latter led only to philanthropy. He also dismisses the Catholic settlements as being more like "missions" and not contributing to legislative reforms. Similarly, Judith Trolander's Professionalism and Social Change (1987) reinforces the idea that the settlement movement was secular. She characterizes the settlements as democratic institutions that operated from a middle-class lens, but were nevertheless successful at advocating for positive change in poor neighborhoods. She also begins to raise the question of whether the settlement houses, or "institutions closer to the ethnic heritage of particular groups, such as the Catholic Church" were better suited to serving the needs of immigrant 
populations. ${ }^{30}$ Within the scholarship this was an early acknowledgment of the ethnic, cultural, and religious distance between the settlement workers and their immigrant neighbors.

In the 1990s, research on the settlements began to pivot to a more cynical portrayal, working from a framework that emphasized the movement's shortcomings in its relationship with immigrants. Rivka Shpak Lissak's Pluralism and Progressives (1989) is a classic example of this approach, also known as the social control thesis. She acknowledges the positive intentions of settlement workers, but argues that "the settlement ideology and its policies were in fact designed to perpetuate the existing social order" by discouraging working-class solidarity and cementing their place as elites in charge of the community. ${ }^{31}$ Lissak claims that settlements worked directly against the class consciousness of immigrant communities even as they supported labor legislation. ${ }^{32}$ Mina Carson's Settlement Folk (1990) also referred to the settlement ideology as a "double-edged sword," pushing to expand the promises of democracy to a greater range of society, but also exerting "far-reaching social control" over populations that didn't seem to conform to appropriate social behavior. ${ }^{33}$ She also proposes that attempts to enrich the lives of the poor through artistic and aesthetic offerings were out of touch with the reality of people's lives. Similarly, Shannon Jackson's Lines of Activity (2000) argues that while settlement women were better at empathizing with their neighbors than many

\footnotetext{
30 Trolander, Professionalism and Social Change, 19.

${ }^{31}$ Lissak, Pluralism and Progressives, 22.

${ }^{32}$ Ibid 16-23.

${ }^{33}$ Carson, Settlement Folk, 7.
} 
charity organizations, their methods also displayed an "authoritarian disposition."34

Jackson also explores the various reasons that poor, immigrant women did not respond to the house in the way Hull-House women hoped, including the fact that it operated in both the public and private sphere at the same time. Katrina Irving in Immigrant Mothers (2000) follows the line of argument that settlements wanted immigrants to "rid themselves of their Old World culture as expeditiously as possible," with a special emphasis on how settlement workers tried to correct the home life of immigrant mothers and make them over into ideal American mothers. ${ }^{35}$

These works are important to developing the uneven power dynamic between settlement residents and their immigrant neighbors, and acknowledging that residents' plans were not always in the best interest of the community at large. However, they tend to overstate their points, sidelining moments where settlement workers helped promote class consciousness and economic mobility, or advocated on behalf of immigrants against other cultural pressures to Americanize. ${ }^{36}$

\footnotetext{
${ }^{34}$ Shannon Jackson, Lines of Activity: Performance, Historiography, Hull-House Domesticity (Ann Arbor, MI: University of Michigan Press, 2000), 12.

${ }^{35}$ Irving, Immigrant Mothers, 9.

${ }^{36}$ For example, Jane Addams was criticized for focusing too much on the small portion of people in the community that would go on to college, and not dealing with the reality of the majority that would remain in unskilled labor positions (Davis, Spearheads, 51); Additionally, Jane Addams pushed back against the public schools' emphasis on teaching English, saying that it increased the generational divide between children and their foreign-born parents, and made them more ashamed of their parents. ("Speech to the American League of Civic Improvement," September 24, 1902, Jane Addams Papers, https://digital.janeaddams.ramapo.edu/items/show/16868).
} 
A concurrent trend in the scholarship began to focus on how reform-minded women used settlement work to carve out a dominion for themselves in an era that still allowed little chance for female professionalization. Robyn Muncy's Creating a Female Dominion in American Reform (1991) points out that women professionals in the Progressive Era and New Deal era focused on the mother-child relationship because it was an arena in which they were ascribed some authority. ${ }^{37}$ She describes the Hull-House women as genuinely committed to reform, but at the same time utilizing the lives of poor women to prove their capability as authority figures. In The Poor Belong to Us (1997), Dorothy M. Brown and Elizabeth McKeown explore how a similar dynamic operated amongst middle-class Catholic laywomen, who based their work on the concept that they had both an obligation and a claim to poor Catholic communities. They also demonstrate how Catholic laywomen's shift towards professionalism (especially when they began earning degrees in social work and requiring salaries for their work) brought them into conflict with members of the clergy, as it violated norms of female self-sacrificing labor in the Church. ${ }^{38}$ And Maureen A. Flanagan's Seeing with their Hearts (2002) examines the specific models of social welfare undertaken among women in Chicago, including Hull-House women. However, Flanagan discusses Catholic women as a monolithic entity, bringing almost no discussion of ethnic or class differences into the narrative. She also overstates the alliances that women in Chicago were building across racial and

\footnotetext{
${ }^{37}$ Muncy, Creating, xv, 36-37.

${ }^{38}$ Brown and McKeown, Poor, 72-76.
} 
religious lines, ignoring the significant cleavages in women's public advocacy caused by these divisions. ${ }^{39}$

At the same time, some authors began working to bring Catholic laywomen further into the narrative of the settlement movement. Margaret McGuinness's article "Body and Soul: Catholic Social Settlements and Immigration” (1995) frames early Catholic settlement work as a response of church leaders struggling to know how to deal with maintaining immigrants' loyalty to the Church as they acculturated to America. She considers the Catholic move into settlement work to be a response to Progressive values and the Social Gospel, but also explores the way individual women turned their religious beliefs into the basis for a new approach to social betterment. ${ }^{40}$ In You Have Stept Out of Your Place (1996), Susan Hill Lindley brings religious women further into the narrative of settlement work, saying the movement shouldn't be seen as a "purely secular or political phenomenon."41 She highlights women like Ellen Gates Starr, Vida Scudder, and Leonora Barry, who combined devotion to religion with devotion to socialist or progressive values. And while it does not discuss settlement work, Kathleen Sprows Cummings's New Women of the Old Faith (2009) examines the way Catholic laywomen rejected the imagery of the New Woman and instead appealed to a history of saintly women as a framework for pushing into greater public positions and exercising more autonomy. Of the research discussing Catholic laywomen, the most significant is

\footnotetext{
${ }^{39}$ Flanagan, Seeing, 6.

${ }^{40}$ Margaret M. McGuinness, "Body and Soul: Catholic Social Settlements and Immigration," US Catholic Historian 13, no. 3 (Summer 1995): 65.

${ }^{41}$ Susan Hill Lindley, "You Have Stept Out of Your Place:" A History of Women and Religion in America (Louisville, KY: Westminster John Knox Press, 1996), 146.
} 
Deborah Skok's More than Neighbors (2007), which focuses on settlement houses founded by Catholic laywomen throughout the country, including the Madonna Center. While still falling firmly on the side that Catholic settlements were there to compete with Hull-House and other non-Catholic settlements, she delves further into the way Catholic laywomen approached their communities and used settlement work to boost their own authority. She introduces the idea that Catholic women had a stronger claim to the title of "neighbor" than Hull-House women did because they could interact with their immigrant neighbors on the basis of shared religion. ${ }^{42}$ However, Skok and Cummings both fall into the trap of ignoring differences of class and ethnicity in their depiction of "Catholic women," instead positioning these middle-class reformers as the representative norm.

A few pieces of scholarship have challenged the dominance of secular settlements in the narrative by claiming that social settlements were actually imitating Catholic charities. Suellen Hoy, in “Caring for Chicago's Women and Girls," argues that Catholic nuns both preceded and laid the groundwork for the settlement house movement and Progressive era social work. ${ }^{43}$ Donna Gabaccia’s "Emancipation and Exploitation in Immigrant Women's Lives" also points to the long history of Catholic women in leadership positions in their own organizations within the Church (like schools, orphanages, and hospitals). And Thomas Davis's "New Directions in Catholic Historical

42 Deborah A. Skok, More than Neighbors: Catholic Settlements and Day Nurseries in Chicago, 1893-1930 (Dekalb, IL: Northern Illinois University Press, 2007), 4.

${ }^{43}$ Suellen Hoy, "Caring for Chicago's Women and Girls: The Sisters of the Good Shepherd, 1859-1911,” Journal of Urban History 23, no. 3 (March 1997): 285-286. 
Research" makes an argument for re-centering Catholic women in the history of social work, with a focus on Ellen Gates Starr's legacy and religious life.

The literature of immigrant communities is full and rich and operates as a historiographical category in its own right. A few of these works have discussed the relationship between settlements and immigrants while focusing on communities' agency and the way they worked on their own behalf. Lizabeth Cohen's Making a New Deal delves into the leadership present among ethnic communities, challenging the view of immigrants as helpless and in need of leaders. She contributes an in-depth view of the way different groups banded together and developed new methods of handling poverty in their own communities. Similarly, Ellen Skerrett's “The Irish of Chicago's Hull-House Neighborhood" criticizes the idea that Jane Addams and Ellen Gates Starr brought beauty, culture, and leadership to the Near West Side. ${ }^{44}$ She points out the agency of Irish Americans in raising money to build their own churches, and the activities of churches and organizations like the Hibernian Society to meet the Irish American community’s needs. In Steel Barrio, Michael Innis-Jiménez says settlement houses played an important role in Mexican communities in Chicago, but also points out that they had their own leaders, challenging previous scholarship that characterized the Mexican community in Chicago as fragmented and lacking leadership. ${ }^{45}$

${ }^{44}$ Ellen Skerrett, "The Irish of Chicago's Hull-House Neighborhood," in New Perspectives on the Irish Diaspora, ed. Charles Fanning (Carbondale, IL: Southern Illinois University Press, 2000), 190-191.

${ }^{45}$ Innis-Jiménez, Steel Barrio, 4-5. 
Finally, Elisabeth Lasch-Quinn's Black Neighbors brings the largely ignored experience of African Americans into the story of the settlements, exposing how most settlement houses failed to adapt to their new black neighbors in the interwar period. Lasch-Quinn also seeks to expand the typical parameters of what constituted a social settlement, bringing in African American institutions that were not counted in the mainstream movement because of their religious affiliations. She points out that religious organizations often held greater appeal for African Americans than the secular settlements, because churches played an important role in most black communities. ${ }^{46}$ While Lasch-Quinn performs the important role of bringing racial analysis into the narrative, her work operates within a black-white binary, overshadowing the experience of Mexican immigrants and ignoring some of the complexity of how racial lines operated within the city.

The concept of space creates a through-line connecting the reform efforts of Catholic and secular women to the patterns of community embodied by their immigrant neighbors. By physically residing in the neighborhoods they sought to aid, settlement houses were drawn into the web of discursive negotiations around nationalism, religion, race, and ethnicity that played out between different groups in the city. Catholic women pushed to strengthen and expand the private sphere of religious organizations while HullHouse women sought to blur the lines of public and private by pushing women's

\footnotetext{
${ }^{46}$ Lasch-Quinn, Black Neighbors, 47-56, see also Patricia A. Schechter, Ida B. WellsBarnett and American Reform (Chapel Hill, NC: The University of North Carolina Press, 2001), 2-3, 172-213.
} 
influence outward into distinctly municipal concerns. Their efforts were shaped by, and in turn shaped, the urban landscape of Chicago. 
Chapter 1 -Contextualizing Chicago: The Neighborhoods, the Churches, and the Settlements

The half-century between 1880 and 1930 was a period of constant demographic shifts in Chicago. The city went from a population of a little over 500,000 to nearly 3.4 million, and by 1890, three-quarters of that population was composed of first-and secondgeneration immigrants. ${ }^{1}$ Much of the overcrowded and insufficient housing in Chicago was due to the destruction of the Great Fire of 1871-after which the city raced to quickly build enough housing so that people wouldn't be left out in the cold during the winter. With the flood of immigrants to the city, houses that were intended to hold only one family began to hold two or three, or even more. ${ }^{2}$

The Near West Side, with its low-cost housing and proximity to many industrial labor centers, was one of the primary areas where immigrants to the city chose to settle. Housing conditions in the Near West Side remained poor because the city expected the neighborhoods to be taken over by factories eventually, so they saw no point in renovating or improving the buildings. Lots of the houses were built partially below ground level by several feet, making them dark, damp, and poorly ventilated. Many people kept chickens, pigs, goats, and other animals in the yards, or in their homes, increasing the potential for diseases to spread. ${ }^{3}$ One report from 1900 described the

\footnotetext{
${ }^{1}$ Susan E. Hirsch, "Ethnic and Civic Leadership in the Progressive Era: Charles H. Wacker and Chicago," Journal of American Ethnic History 35, no.4 (Summer 2016): 5. ${ }^{2}$ Hilda Satt Polachek, I Came a Stranger: The Story of a Hull-House Girl, ed. Dena J. Polachek Epstein (Urbana, IL: University of Illinois Press, 1970), 71.

${ }^{3}$ Hull House Maps and Papers (New York, NY: Thomas Y. Crowell \& Company, 1895), 10; "Chicago's Housing Conditions," The Charities Review 10, no. 7 (1900): 293; Natalie Walker, "Chicago Housing Conditions. X. Greeks and Italians in the Neighborhood of Hull House,” American Journal of Sociology 21, no. 3 (1915): 313.
} 
neighborhood as follows: "Pools of stagnant water abound; open ditches clogged with silt, garbage, and refuse; privy vaults and cesspools overflow the surrounding country after every rainfall; decomposing animal and vegetable matter, from kitchen waste to dead animals, litter yards, alleys, roadways, and vacant lots." 4 The area also had a high density of children-by $1914,30 \%$ of the population in the Hull-House neighborhood was under the age of twelve. ${ }^{5}$

As these new waves of Southern and Eastern Europeans gathered in the city, they often formed insular enclaves, clustering by necessity with fellow nationals who spoke the same language. In 1889, when Jane Addams and her friend Ellen Gates Starr opened Hull-House, one of the very first American settlement houses, on the corner of Halsted and Polk street in Chicago's Near West Side, the neighborhood had shifted from a working-class Irish area to large colonies of Greek and Italian immigrants.

\section{The Settlements: A Brief Timeline}

The purpose of Hull-House, as stated in its charter, was to "provide a center for the higher civic and social life; to institute and maintain educational and philanthropic enterprises, and to investigate and improve the conditions in the industrial districts of Chicago." ${ }^{6}$ Addams and Starr, as well as other reformers who would join the settlement house movement in coming years, believed that the act of residing in the poor neighborhoods they hoped to assist distinguished them from other philanthropic

\footnotetext{
4 “Chicago's Housing Conditions," 293-294.

5 Walker, "Chicago Housing Conditions," 289.

${ }^{6}$ Robert A. Woods and Albert J. Kennedy, Handbook of Settlements (New York, NY: The Russell Sage Foundation, 1911), 53.
} 
institutions, and made their work more effective. Residence would help overcome class boundaries by bringing those with resources and those without into "harmonious and helpful relationships."7 The founders believed that "the mere foothold of a home easily accessible, ample in space, hospitable and tolerant in spirit, situated in the midst of the large foreign colonies which so easily isolate themselves in American cities, would be itself a serviceable thing for Chicago." "In this way, they would become more than charity-workers, ideally building personal relationships with the members of poor immigrant communities as neighbors. Samuel Barnett, founder of Toynbee House, the original settlement house in England, wrote that the best residents were those who "live in such contact with their neighbors as to have formed among them a number of equal friendships."9

\footnotetext{
${ }^{7}$ Clippings 1895-1899, box 48, folder 509, Hull-House Collection, Special Collections and University Archives, University of Illinois at Chicago; Addams noted in 1905 that efforts in New York to combat tuberculosis had been more successful in areas where workers had managed to build relationships with those that lived in the tenements, in "The Immigrants and American Charities," October 24, 1905, Jane Addams Papers, https://digital.janeaddams.ramapo.edu/items/show/3813; Jane Addams, Twenty Years at Hull-House with Autobiographical Notes (New York, NY: The MacMillan Company, 1930), 119-126; Charlene Haddock Seigfried, "Socializing Democracy: Jane Addams and John Dewey," Philosophy of the Social Sciences 29, no. 2 (June 1999): 207. ${ }^{8}$ Hull-House Yearbook September 1906-September 1907, box 43, folder 434, HullHouse Collection.

${ }^{9}$ Samuel A. Barnett, "Education by Permeation" (1906), in Readings in the Development of Settlement Work, ed. Lorene M. Pacey (New York, NY: Association Press, 1950), 82; see also Judith Trolander, Professionalism and Social Change: From the Settlement House Movement to Neighborhood Centers 1886 to the Present (New York, NY: Columbia University Press, 1987), 2-11; Mary Jo Deegan, Race, Hull-House, and the University of Chicago: A New Conscience Against Ancient Evils (Westport, CT: Praeger, 2002), 16.
} 
The settlement movement began to take off in Chicago in the 1890s. The 1893 World's Columbian Exposition inspired a surge of reform efforts throughout the city, among both religious and secular figures. In its wake, three Catholic social settlements were founded-St. Anne's on the West Side, St. Elizabeth's on the North Side, and All Saints (later St. Mary’s) on the South Side. ${ }^{10}$ Northwestern University Settlement had opened in 1891, and the University of Chicago Settlement, founded by social reformer Mary McDowell, followed in 1894. The same year, Professor Graham Taylor opened the Chicago Commons with a few students from his seminary. Like Hull-House, they tended to choose neighborhoods where an older Irish and German population was being supplanted by newer immigrants from Southern and Eastern Europe. In 1900, Minister Reverdy Ransom of the African Methodist Episcopal Church also opened the Institutional Church and Social Settlement in Chicago's Black Belt, “to better conditions among the poor of all classes." 11

The heavy immigrant population and poor housing conditions of the Near West Side continued to attract the attention of reform-minded women. The women of the Sodality of the Children of Mary, after discussing the "spiritual needs of the extensive West Side Italian Colony,” decided to found a Sunday School in $1898 .^{12}$ By 1903, the Sunday School, led by Agnes Amberg, had over 1400 children attending. The school

\footnotetext{
${ }^{10}$ Charles Shanabruch, Chicago's Catholics: The Evolution of an American Identity (Notre Dame, IN: University of Notre Dame Press, 1981), 131-132.

${ }^{11}$ Woods and Kennedy, Handbook, 40-77.

${ }^{12}$ Christ-Child Society of Chicago 1915-1916, Madonna Center Records, series 1, box 2, folder 7, Mary Agnes Amberg Papers, Special Collections and University Archives, Marquette University.
} 
expanded rapidly, and began adding more activities for children, and classes for adults in the basement of Holy Guardian Angel Church. The expanded organization became known as Guardian Angel Mission. In 1914, Agnes Amberg's daughter Mary, (with her friends Catherine Jordan and Marie Plamondon), moved into the mission as residents, officially transforming it into a social settlement. In a bid to appeal more to the Italian community, they changed the name to Madonna Center. ${ }^{13}$ The Center would become one of the nation's most prominent social settlements.

\section{Locations of Major Catholic Immigrant Groups in Chicago}

The first Irish migrants to Chicago were laborers employed in digging canals; many of them set up in Bridgeport, which would become one of the major Irish neighborhoods in Chicago. By 1880, Bridgeport held about a quarter of the city's Irish population. By the last quarter of the century, another significant Irish community had developed around Holy Family Church, a few blocks southwest of Hull-House. Though they clustered in the South and West sides of the city, the Irish were more geographically spread out than other groups in Chicago. In 1884 they formed a majority in only 11 out of 303 census districts. Irish-Americans remained the dominant group in the Near West Side until the 1890 s, when it began to transform into a largely Italian neighborhood. ${ }^{14}$

\footnotetext{
${ }^{13}$ Mary Agnes Amberg, Madonna Center: Pioneer Catholic Settlement (Chicago, IL: Loyola University Press, 1976), 52, 87-89, 121-123; see also Margaret A. Galvin, "The Growth and Development of Madonna Center, a Catholic Social Settlement" (master's thesis, Loyola University, 1951).

${ }^{14}$ Ellen Skerrett, Edward R. Kantowicz, and Steven M. Avella, Catholicism, Chicago Style (Chicago, IL: Loyola University Press, 1993), 8; Michael F. Funchion, "Irish Chicago: Church, Homeland, Politics, and Class-The Shaping of an Ethnic Group, 18701900," in Ethnic Chicago, ed. Peter d'A Jones and Melvin G. Holli (Grand Rapids, MI:
} 
By 1884 , the city's largest Italian immigrant population resided on the Near West Side, forming a strip between Harrison and Twelfth (now Roosevelt) streets. The largest surge in Italian immigration occurred at the turn of the century-between 1900 and 1910, the Italian population of the Near West Side jumped from 5,000 to 25,000 residents. The men were often recruited to work seasonally on the railroads, while many women and children worked in the garment industry, including as home finishers, completing garments in their own homes at a piece rate. ${ }^{15}$ In 1901 the City Homes Association labelled the area between Polk, Twelfth, Canal, and Halsted (encompassing Hull-House and the blocks directly to the south and east) the "Italian District." Chicago's current "Little Italy" still occupies the area south of Hull-House and the University of Illinois at Chicago. By 1915, Italians still comprised $72 \%$ of the Hull-House neighborhood. ${ }^{16}$

Chicago also held the cultural center of the American Polish community, also known as Polonia or Polonia Amerykánska. By the mid-1880s, the Polish population in

William B. Eerdmans Publishing Company, 1981), 11; Lawrence J. McCaffrey, "The Irish American Dimension," in The Irish in Chicago, eds. Lawrence J. McCaffrey, Ellen Skerrett, Michael F. Funchion, and Charles Fanning (Champaign, IL: University of Illinois Press, 1987), 7; Dominic A. Pacyga, Chicago: A Biography (Chicago, IL: University of Chicago Press, 2009), 114.

${ }^{15}$ Rivka Shpak-Lissak, Pluralism and Progressives: Hull House and the New Immigrants, 1890-1919 (Chicago, IL: University of Chicago Press, 1989), 95-108; Guglielmo, White on Arrival: Italians, Race, Color, and Power in Chicago, 1890-1945 (New York, NY: Oxford University Press, 2003), 18; Victor Greene, "'Becoming American:' The Role of Ethnic Leaders-Swedes, Poles, Italians, and Jews," in The Ethnic Frontier: Essays in the History of Group Survival in Chicago and the Midwest, ed. Melvin G. Holli and Peter d'A Jones (Grand Rapids, MI: Williams B. Eerdman's Publishing Company, 1977), 159160; Hull-House Maps and Papers, 33.

${ }^{16}$ Humbert S. Nelli, Italians in Chicago 1880-1930: A Study in Ethnic Mobility (New York, NY: Oxford University Press, 1970), 31; Walker, "Chicago Housing Conditions," 290. 
Chicago had reached over 45,000; by 1910 it had increased to almost 250,000. By 1930 they had become the largest white ethnic group in Chicago, comprising $12 \%$ of the city's total population. The largest community was centered around St. Stanislaus Kostka Church, established in 1870 at Noble and Bradley streets. Two decades later this area, alternatively called the St. Stanislaus District, Little Poland, or Polish Downtown, held close to half of the city's Polish population. By 1910, other areas of significant Polish settlement in the city included South Chicago, Back-of-the-Yards, St. Adalbert's, and Bridgeport. ${ }^{17}$

However, a long history of anti-Semitism divided the community between Catholics and Jews. ${ }^{18}$ The majority of Polish people on the Near West Side were Jewish, but the greater "Polonia" did not always consider such neighbors to be adequately "Polish.” For example, Rogers Park was an area heavily populated by Polish Jews, but most Chicagoans did not consider it to be a Polish neighborhood. Roman Catholicism and national identities were so intertwined that many American Poles viewed Catholicism as a prerequisite for being "Polish" at all. ${ }^{19}$

\footnotetext{
${ }^{17}$ Kantowicz defines the boundaries of this area as bordered on the east by the Chicago River, the west by Milwaukee Avenue, and the north and south by Fullerton Avenue and Chicago Avenue, in Edward R. Kantowicz, Polish-American Politics in Chicago 18881940 (Chicago, IL: The University of Chicago Press, 1975), 8-18.

${ }^{18}$ For more on experiences of anti-Semitism in Poland, see Hilda Satt Polachek, I Came a Stranger.

${ }^{19}$ Edward R. Kantowicz, "Polish Chicago: Survival Through Solidarity," in The Ethnic Frontier: Essays in the History of Group Survival in Chicago and the Midwest, ed. Melvin G. Holli and Peter d'A Jones (Grand Rapids, MI: William B. Eerdman's Publishing Company, 1977), 180; Greene, "Becoming," 152-153.
} 


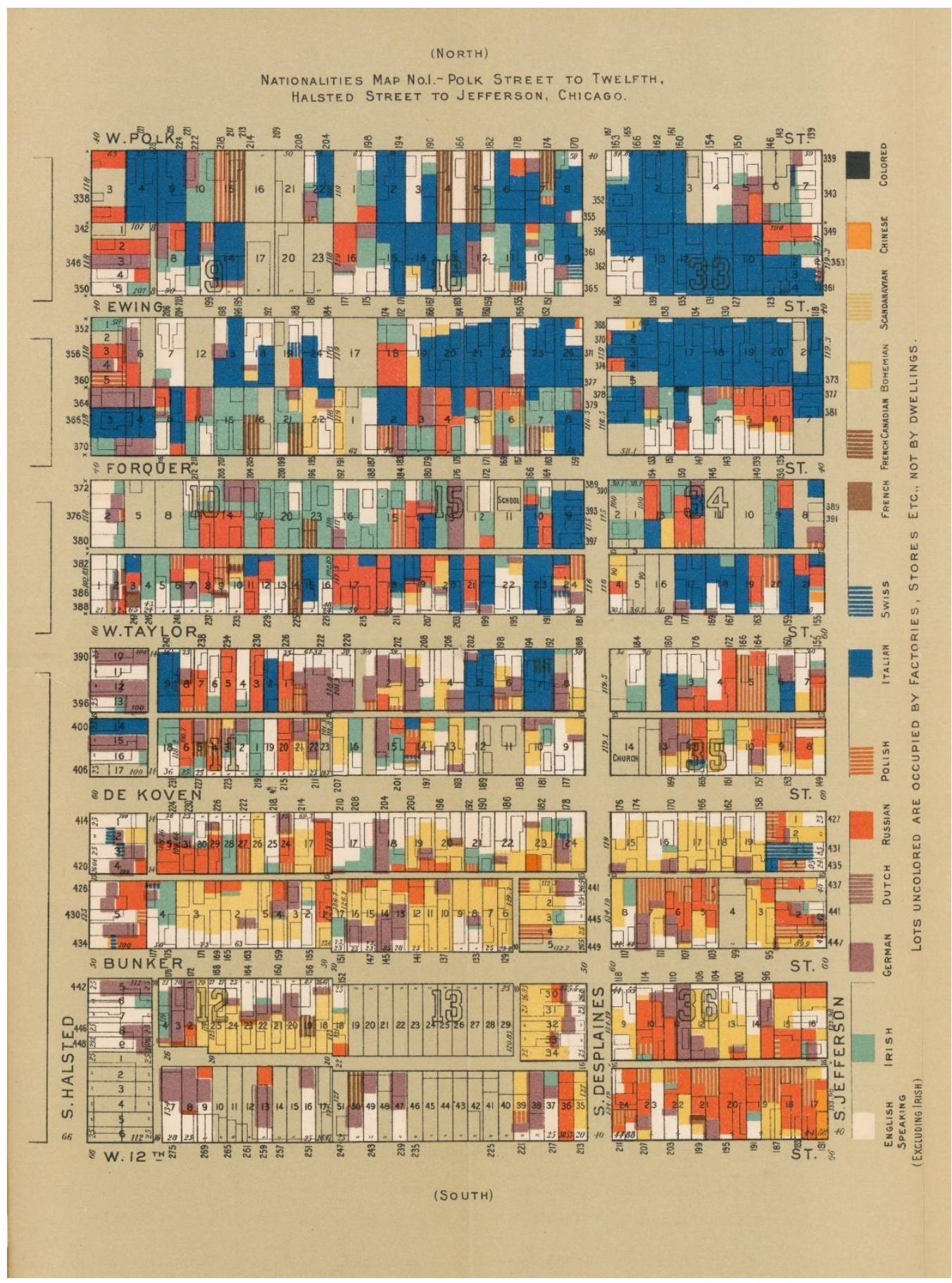

A section of the Nationalities Map published in Hull-House Maps and Papers, 1895. Image reproduced with permission of Cornell University - PJ Mode Collection of Persuasive Cartography. 
Up until World War I, these groups formed the major Catholic immigrant contingent in the city. The period between 1916 and 1919 marked the beginning of another demographic shift as Mexican immigrants began to arrive in large numbers. In the wake of the 1919 race riot and steel strikes, steel mills were reluctant to hire African Americans for fear of igniting further racial tension, so they actively recruited Mexican men to fill the openings. ${ }^{20}$ Others were migrant workers looking to supplement their agricultural labor during the off season, and still others were fleeing revolutionary violence in Mexico, looking for a place to start over with new opportunities. ${ }^{21}$

Between 1920 and 1930, the Mexican population in Chicago increased by about 20,000 people. Like previous groups of immigrants, they settled in neighborhoods around centers of employment-the Near West Side, Packinghouse, Back-of-the-Yards, and South Chicago. ${ }^{22}$ Mexican immigrants were also attracted to the services that settlement houses offered, and many chose to cluster around settlements for this reason. In 1927, the HullHouse neighborhood had the largest Mexican population in the city, with another large group residing around the University of Chicago settlement on the South Side. By the end of the 1920s, the Hull-House neighborhood also contained the most Mexican-owned

\footnotetext{
${ }^{20}$ Michael Innis-Jiménez, Steel Barrio: The Great Mexican Migration to South Chicago, 1915-1940 (New York, NY: New York University Press, 2013), 32-33.

${ }^{21}$ George J. Sánchez, “'Go After the Women:' Americanization and the Mexican Immigrant Woman, 1915-1929," in Unequal Sisters: A Multicultural Reader in U.S. Women's History, eds. Vicki L. Ruiz and Ellen Carol DuBois (New York, NY: Routledge, 1994), 285-286; Gabriela Arredondo, Mexican Chicago: Race, Identity, and Nation, 1916-39 (Urbana, IL: University of Illinois Press, 2008), 27-36; Innis-Jiménez, Steel Barrio, 20-47.

${ }^{22}$ Arredondo, Mexican Chicago, 28; Gabriela F. Arredondo, "Navigating Ethno-Racial Currents: Mexicans in Chicago, 1919-1939," Journal of Urban History 30, no. 3 (March 2004): 401.
} 
businesses in the city, including fourteen restaurants, five grocery stores, four bakeries, a barber shop, a meat market, and more. ${ }^{23}$ However, these communities were dramatically reduced by deportation campaigns in the 1930s. Historian Gabriela Arredondo estimates that these programs removed about $25 \%$ of Chicago's Mexican population. When the Great Depression hit, others voluntarily returned to Mexico due to the shortage of jobs. ${ }^{24}$

Finally, the African American community began to expand rapidly around the same time the Mexican migrant community did. The Great Migration doubled Chicago’s African American population between 1916 and $1919 .{ }^{25}$ Since racial housing restrictions limited their choices, the majority of these migrants from Southern states settled in the city's "Black Belt"-a historically black series of neighborhoods on the South Side. These neighborhoods, including Washington Park, Grand Boulevard, and Bronzeville, formed a narrow strip running north-south for more than thirty blocks. The Near West Side also became a significant black settlement; in 1930 African Americans made up over half of the neighborhood's population. ${ }^{26}$

${ }^{23}$ Peggy Glowacki, "Bringing Art to Life: The Practices of Art at Hull House," in Pots of Promise: Mexicans and Pottery at Hull House, 1920-1940, eds. Cheryl R. Ganz and Margaret Strobel (Chicago, IL: University of Illinois Press, 2004), 22; Robert C. Jones and Louis R. Wilson, The Mexican in Chicago (Chicago, IL: Chicago Congregational Union, 1931), 12; Arredondo, Mexican Chicago, 48; Anita Edgar Jones, "Mexican Colonies in Chicago," Social Services Review 2, no. 4, (Dec 1928): 590.

${ }^{24}$ Arredondo, "Navigating," 407; Innis-Jimenéz, Steel Barrio, 5.

${ }^{25}$ Guglielmo, White on Arrival, 40.

${ }^{26}$ Pacyga, Chicago, 205, 225-226; James R. Grossman, "Southern Blacks' Migration to Chicago in the Early Twentieth Century," in Major Problems in American Urban and Suburban History, ed. Howard P. Chudacoff and Peter C. Baldwin, (Boston, MA: Houghton Mifflin Company, 2005): 253; Guglielmo, White on Arrival, 47. 
The main center of the black Catholic community in South Chicago was St. Monica, established in 1894 as the city's first Catholic church for African Americans. In the 1920 s, St. Monica combined with the remnants of a nearby parish to become St. Elizabeth's. Though St. Monica was later designated for African Americans, Chicago's black Catholics usually didn't form "national" parishes like their immigrant counterparts, because they already spoke English. Rather, they attended the (Irish American) territorial parish in the area, often encountering a great deal of tension and aggression from the older congregation. St. Anselm Church, located a few blocks southeast of the University of Chicago, was the site of drawn-out conflict as it transitioned from an Irish church to a majority African American community. ${ }^{27}$ In 1933, Holy Family sponsored the St. Joseph Mission for African Americans on nearby $13^{\text {th }}$ Street on the Near West Side. ${ }^{28}$ This indicates a potentially more comfortable relationship between black and Irish Catholics than on the South Side-however, it's possible that this was also a move to separate black parishioners from the main church. John McGreevy also writes that as a parish went through the transition from one European immigrant group to another, it was a gradual process, but when it transitioned to an African American population, the white Catholic parishioners would abandon the neighborhood "wholesale."29

${ }^{27}$ John T. McGreevy, Parish Boundaries: The Catholic Encounter with Race in the Twentieth-Century Urban North (Chicago, IL: University of Chicago Press, 1996), 3536; Timothy Neary, "Black-Belt Catholic Space: African American Parishes in Interwar Chicago," U.S. Catholic Historian 18, no. 4 (Fall 2000): 79.

${ }^{28}$ Jack Bochar, Locations of Chicago Roman Catholic Churches 1850-1990 (Sugar Grove, IL: The Czech and Slovak American Genealogy Society of Illinois, 1997), 34.

${ }^{29}$ McGreevy, Parish Boundaries, 35. 
The Churches

This period of mass immigration simultaneously built up and challenged the Catholic Church in Chicago. For most of the nineteenth century the Church had consisted mostly of German and Irish congregations; by the final decades it had become the most ethnically diverse archdiocese in the United States. The 1880s and 1890s were a period of intense church-building in Chicago-between 1880 and 1890, the Church increased from thirty-one to eighty-one parishes. ${ }^{30}$ This gave Catholics greater visibility in the city, but the archdiocese remained incredibly divided and decentralized. The Church did not have a unified Catholic body so much as a loose amalgam of cultural groups, mostly clustered around national (or "ethnic") parishes-churches based around a particular nationality group rather than a geographic territory. ${ }^{31}$ By 1870 , non-English-speaking parishes had surpassed English-speaking ones. And by 1916, 65\% of Chicago Catholics worshipped in these national parishes. ${ }^{32}$

The leadership of the Church, as was the case throughout American cities, was dominated by Irish-Americans. Between 1849 and 1915, every bishop and archbishop was of Irish descent (George Mundelein, who became archbishop in 1915, had a German

\footnotetext{
${ }^{30}$ Skerrett, Kantowicz, and Avella, Catholicism, Chicago Style, xvii; Shanabruch, Chicago's Catholics, 58.

${ }^{31}$ See Shanabruch, Chicago's Catholics, 74-87; Skerrett, Kantowicz, and Avella, Catholicism, Chicago Style, xvii-xxi; Philip Gleason and David Salvaterra, "Ethnicity, Immigration, and American Catholic History," Social Thought 3 (1978): 11-15; R.A. McEachen, "Our Five Million Immigrants," in The First American Catholic Missionary Congress, ed. Francis C. Kelley (Chicago, IL: J.S. Hyland and Company, 1908).

${ }^{32}$ Shanabruch, Chicago's Catholics, 17; McGreevy, Parish Boundaries, 13.
} 
father and an Irish mother). ${ }^{33}$ The Irish differed dramatically from the "new immigrants" in language, worship styles, and manner of relating to the Church. ${ }^{34}$ These new parishioners tended to identify strongly with their own communities over Church leaders, causing internal clashes over the competing values of religious solidarity and cultural autonomy. ${ }^{35}$ However, up until the World War I period, many Chicago Church leaders supported the idea of national parishes. In 1891 the St. Raphael's Society published the Lucerene Memorial, a document claiming that the Church in the US had lost 10 million adherents among its immigrant populations, and promoted national parishes as the solution. Archbishop Quigley agreed that this was a valuable manner of encouraging

${ }^{33}$ McCaffrey, "Irish American," 12.

${ }^{34}$ See Shanabruch, Chicago's Catholics, 37-45; Nelli, Italians, 181-183; Mary Elizabeth Brown, "The Making of Italian-American Catholics: Jesuit Work on the Lower East Side, New York, 1890-1950s," Catholic Historical Review 73, (1987): 217; Gleason and Salvaterra, "Ethnicity," 8-9; Skerrett, Kantowicz, and Avella, Catholicism, Chicago Style, 11-12; Susan Hill Lindley, 'You Have Stept Out of Your Place:' A History of Women and Religion in America (Louisville, KY: Westminster John Knox Press, 1996), 200-207; David A. Badillo, Latinos and the New Immigrant Church (Baltimore, MD: The Johns Hopkins University Press, 2006), xii-xix; Shannon Jackson, Lines of Activity:

Performance, Historiography, Hull-House Domesticity (Ann Arbor, MI: The University of Michigan Press, 2000), 52; James R. Barrett and David R. Roediger, "The Irish and the 'Americanization' of the 'New Immigrants' in the Streets and in the Churches of the Urban United States, 1900-1930," Journal of American Ethnic History 24, no. 4 (2005): 17-20.

35 Badillo, Latinos, 40-43; Barrett and Roediger, "The Irish," 17-20; John Radziłowski, The Eagle and the Cross: A History of the Polish Roman Catholic Union of America, 1873-2000 (New York, NY: Columbia University Press, 2003), 25; Shanabruch, Chicago's Catholics, 78-127; Richard M. Linkh, American Catholicism and European Immigrants, 1900-1924 (Staten Island, NY: Center for Migration Studies, 1975), 2-45. 
immigrants' loyalty to the Church, and personally helped found and finance several Italian churches during his tenure. ${ }^{36}$

Churches acted as a center of many immigrant communities, declaring their presence in the bustling urban space. Religious institutions helped orient and define the boundaries of a particular community. ${ }^{37}$ Different nationality groups related differently to the Church, but overall, national parishes acted as valuable institutions for maintaining and passing on a group's culture and language.

In 1857 an Irish congregation funded the massive Holy Family Parish on the West Side. At a cost of $\$ 200,000$ (over $\$ 5.5$ million in 2019 dollars) it was the most expensive church in Chicago in the 1850s ${ }^{38}$ According to Ellen Skerrett, the church became an "undisputed symbol of Catholic confidence and respectability," its events drawing widespread coverage in Chicago newspapers. ${ }^{39}$ The annual St. Patrick's Day parades demonstrated a public celebration of pride in both Irish and Catholic identity. Beyond just establishing their space in the neighborhood, Irish Catholics felt the practices of the Church gave them a platform for rejecting stereotypes of the Irish as perpetual drunkards and brawlers. During the Corpus Christi and Confirmation Day parades, Skerrett writes

\footnotetext{
${ }^{36}$ Shanabruch, Chicago's Catholics, 90, 125-126; Lizabeth Cohen, Making a New Deal: Industrial Workers in Chicago, 1919-1939 (New York, NY: Columbia University Press, 1990), 88.

${ }^{37}$ McGreevy, Parish Boundaries, 4-21; Neary, "Black-Belt," 77.

${ }^{38}$ Ellen Skerrett, "The Irish of Chicago's Hull-House Neighborhood," in New Perspectives on the Irish Diaspora, ed. Charles Fanning (Carbondale, IL: Southern Illinois University Press, 2000), 193.

${ }^{39}$ Skerrett, Kantowicz, and Avella, Catholicism, Chicago Style, 145.
} 
that "the sight of hundreds of children dressed in white marching through the neighborhood" offered an image of devotion and "decorum."40

St. Stanislaus Kostka, led by the prolific Reverend Wincenty Barzynski, was the undisputed center of Polish Catholic life in Chicago. By 1890 the Church had nearly 40,000 members, and at the 1893 Chicago World's Fair, it was hailed as the largest Catholic parish in the world. It even generated its own funds through an independent savings and loan association. ${ }^{41}$ The Polish Catholic community was highly unified and organized. Historian Edward Kantowicz writes that the community approached "institutional completeness"-they created so many institutions that they were able to provide for nearly all of their own religious, political, and educational needs. ${ }^{42}$

The first Italian parish in Chicago was Assumption, founded in 1886 near Orleans Street on the Near North Side. ${ }^{43}$ Despite the large population, Italians on the Near West Side went without a church of their own for many years, having to travel to Assumption if they wanted to hear mass in their own language. Italian-speaking priests were in short supply in Chicago, but Father Edmund Dunne-an Irish priest who spoke fluent Italianbegan leading a congregation in the basement of Holy Family.

40 Skerrett, "Irish of Chicago's Hull-House,” 210.

${ }^{41}$ Greene, "Becoming," 155; Kantowicz, Polish-American Politics, 31-32; Radziłowski, Eagle, 46.

42 Kantowicz, "Polish Chicago," 184.

${ }^{43}$ Nelli, Italians, 31. 


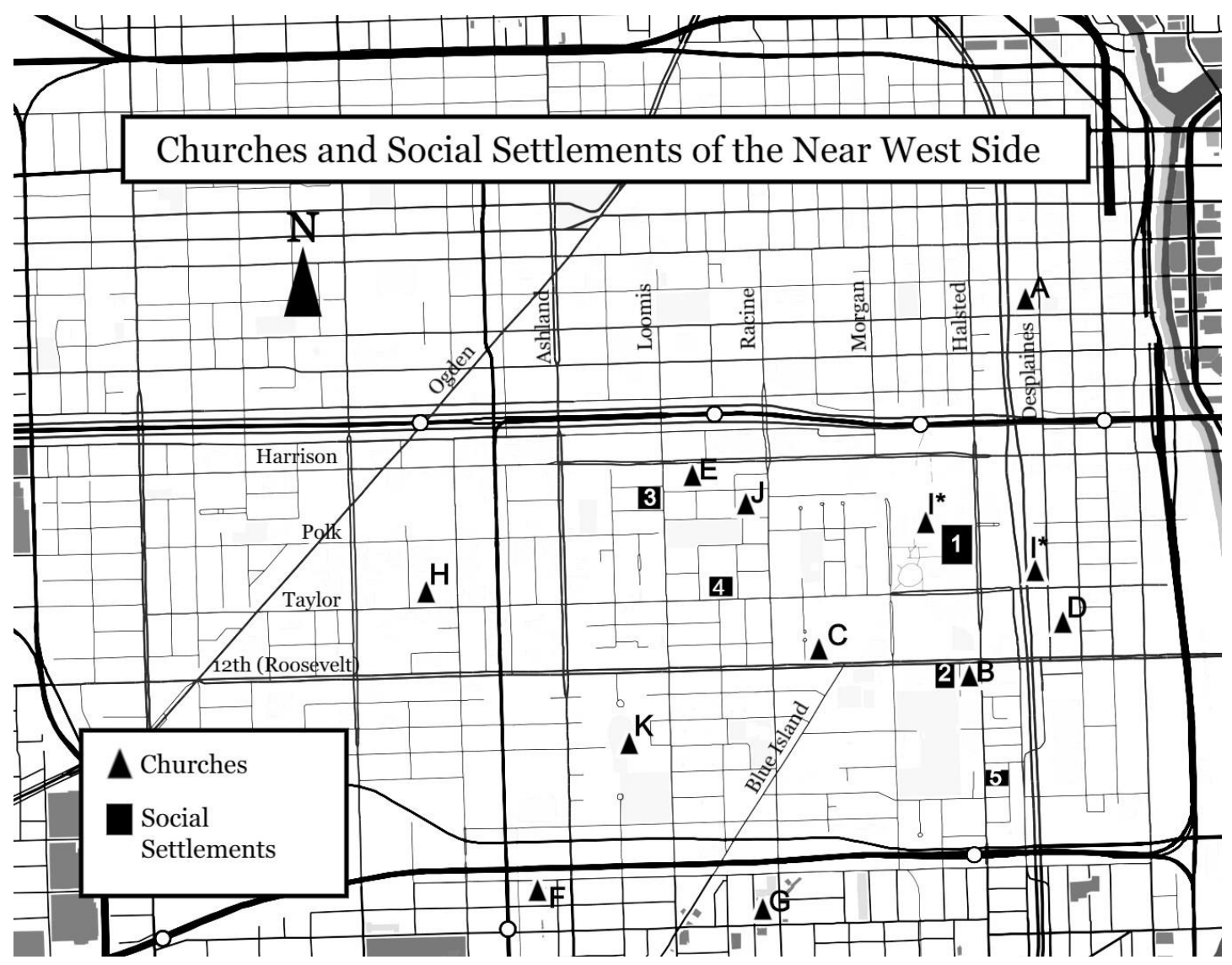

$\underline{\text { Key }}$

A - St. Patrick (1846) - Irish

B - St. Francis of Assisi (1853) - Originally German, then transitioned to Italian and Mexican congregations

C - Holy Family (1857) - Irish

D - St. Wenceslaus (1863) - Bohemian

E - Notre Dame (1864) - French

F - St. Adalbert's (1873) - Polish

G - St. Procopius (1875) - Czech

H - Holy Trinity (1885) - German

I* - Holy Guardian Angel (1898) - Italian, later Mexican congregation

J - Our Lady of Pompeii (1911) - Italian

K - St. Joseph Mission (1933) - African American

* Map shows both original location of the church at Forquer and Desplaines Streets, and second location at Cabrini and Blue Island Avenue
1 - Hull-House (1889)

2 - First location of Guardian Angel Mission at the St. Francis of Assisi School (1912)

3 - Final location of Guardian Angel Mission/Madonna Center on Loomis Street (1922)

4 - Chicago Hebrew Institute (1906)

5 - Henry Booth House (1906)

Map by author. (c) Johanna Katherine Murphy, 2020. 
In 1898 they formed Holy Guardian Angel Church, located only a few blocks from HullHouse. ${ }^{44}$ By 1903 the church had over a thousand families in regular attendance. In 1910, a branch of the congregation split off and formed Our Lady of Pompeii Church a few blocks away, next to Arrigo Park. 1910 was also the "high point" for Italian national parishes-about $75 \%$ of the first- and second-generation Italians in the city were attending one of these churches at the time. ${ }^{45}$ Since Church leaders observed that Italian men rarely attended church, this relatively high presence of Italian "families" at Holy Guardian Angel and Our Lady of Pompeii probably indicate that the women of the community valued the regular devotional practices of Sunday mass. Or at least that they appreciated the opportunity to engage in these practices in an environment defined around their culture, rather than the fornal Irish-American churches. ${ }^{46}$

As some Italians began moving out of the neighborhood, Mexicans began attending Holy Guardian Angel and Our Lady of Pompeii. St. Francis of Assisi, which had shifted from a German to an Italian congregation, was also the first church to begin outreach towards Mexican immigrants. With a Claretian reverend who could give

${ }^{44}$ Holy Guardian Angel Parish had to relocate to make way for the construction of the Dan Ryan Expressway in the late 1950s, and then was demolished in the 1960s during the construction of the University of Illinois at Chicago campus (Pacyga, Chicago, 338). Its original location, according to Mary Amberg, was at Forquer and Desplaines Street, a few blocks southeast of Hull-House (Amberg, Madonna Center, 69). Bochar lists its secondary location as the intersection between Cabrini and Blue Island Avenue, which is now in the middle of the UIC campus (Bochar, Locations, 45).

${ }^{45}$ Nelli, Italians, 190-194; Deborah A. Skok, More than Neighbors: Catholic Settlements and Day Nurseries in Chicago, 1893-1930 (Dekalb, IL: Northern Illinois Press, 2007), 76.

${ }^{46}$ See Linkh, American Catholicism, 40-45; Cohen, Making, 87; Lindley, You Have Stept, 203-204; Skok, More than Neighbors, 82. 
sermons in Spanish, St. Francis of Assisi eventually became known as the "Mexican Cathedral" of the Near West Side.${ }^{47}$ Chicago's first fully Spanish-speaking church was Our Lady of Guadalupe, opened in 1923 on the South Side. ${ }^{48}$ A man named Richard Rodriguez recalled the value of the church to his family: "And in those years when we felt alienated from los gringos," he wrote, "my family went across town every week to the wooden church of Our Lady of Guadalupe, which was decorated with yellow Christmas lights all year long."

Like the Italian community, the archdiocese of Chicago struggled with a shortage of Spanish-speaking priests. In 1924 they brought in the Claretian Order, a group originally from Spain that had been expelled from Mexico during the Revolution. Because the Spanish order touched off some political tension in the community, in the late 1920s they also brought in the Cordi-Marian sisters from Mexico, who helped to bridge the gap between the Mexican community and the Spanish clergy. ${ }^{50}$

Nationality, Space, and Whiteness in the City

Because successive waves of immigrants tended to settle near their locations of employment, areas like the Near West Side and South Chicago were constant sites of

${ }^{47}$ Nelli, Italians, 193, Arredondo, Mexican Chicago, 41; David A. Badillo, "Incorporating Reform and Religion: Mexican Immigrants, Hull House, and the Church," in Pots of Promise: Mexicans and Pottery at Hull House, 1920-1940 (Chicago, IL: University of Illinois Press, 2004), 45; Badillo, Latinos, 89.

${ }^{48}$ Innis-Jimenéz, Steel Barrio, 91.

${ }^{49}$ Quoted in Davis Cyprian, "The Hispanic Catholics," in A Church of Many Cultures: Selected Historical Essays on Ethnic American Catholicism, ed. Dolores Liptak (New York, NY: Garland Publishing Inc., 1998), 149.

${ }^{50}$ Innis-Jiménez, Steel Barrio, 92; Badillo “Incorporating," 46. 
shifting demographics and tension over jobs and housing. Boundaries were constantly being challenged and reinforced through housing exclusion, prejudice, and in extreme cases, outbreaks of violence.

While material concerns like housing and jobs generated competition between immigrant groups, the far more dubious concept of whiteness drove much of the underlying tension over space. The high volume of immigration caused a seismic shift in Progressive-era concepts of race, turning whiteness into something of a moving target. Racial scientists of the period were inconsistent in their definitions of whiteness, sometimes basing it around language, in other cases around physical features, or even perceived fitness for democracy. They also categorized multiple "white races" in this period, rather than one race that encompassed all of Europe.$^{51}$ Some immigrant groups found themselves ambiguously racialized as less-than-white-not Anglo-Saxon, but not necessarily "colored people" either. European immigrants quickly realized that whiteness was the key to gaining respect and mobility in America, and that the main way they could climb the proverbial racial ladder was to distance themselves from those excluded from the category of "white". Association-usually through housing and employment proximity-with clearly nonwhite groups could throw a European groups' whiteness into

${ }^{51}$ Linda Joyce Brown, The Literature of Immigration and Racial Formation: Becoming White, Becoming Other, Becoming American in the Late Progressive Era (New York, NY: Routledge, 2004), 19-20; Matthew Frye Jacobson, Whiteness of a Different Color: European Immigrants and the Alchemy of Race (Cambridge, MA: Harvard University Press, 1999) 6-7, 39-41; Guglielmo, White on Arrival, 61-63. 
question. ${ }^{52}$ The process of mapping out one's space in the city thus became a symbolic process of defending one's place within the racial hierarchy.

For much of the nineteenth century Irish immigrants were not considered white, and due to poverty they often lived in close proximity to African-Americans, further distancing them from contemporary conceptions of whiteness. Earlier in the century, many Americans even depicted them as being racially closer to African Americans than to white Anglo-Saxons. ${ }^{53}$ Efforts to distance themselves from the black population thus characterized much of the way Irish Chicagoans related to the city in the nineteenth century. These efforts translated into territorialism and violence, expressed in Chicago by Irish gangs like the Colts. As African-Americans began to move into the historically Irish neighborhoods on the South Side, Irish men increasingly viewed them as a threatening competition for jobs and housing. ${ }^{54}$ This tension erupted in the infamous 1919 race riots, in which Irish men were responsible for much of the violence against African Americans. The worst clashes occurred along Wentworth Avenue, which had long been a border between Irish neighborhoods and the "Black Belt." Youth gangs imitated the same patterns of aggression, defending their "turf" from other boys. The area around Holy Family Church had one of the highest rates of youth violence in the city. ${ }^{55}$ Patricia Kelleher writes that Irish women, with higher rates of employment in wage labor than

\footnotetext{
52 Jacobson, Whiteness, 57.

${ }^{53}$ Noel Ignatiev, How the Irish Became White (New York, NY: Routledge, 1995), 41-59. ${ }^{54}$ Pacyga, Chicago, 152; see also Christopher Robert Reed, "The Early African American Settlement of Chicago, 1833-1870," Journal of the Illinois State Historical Society 108, no.4 (Fall/Winter 2015): 241.

${ }^{55}$ Barrett and Roediger, "The Irish," 8-14; McGreevy, Parish Boundaries, 1.
} 
most other immigrant groups, were also spurred by job competition to "adopt a strategy of emphasizing whiteness." 56 Newer immigrants perceived the Irish to be more aggressive towards other nationality groups in general, including strong expressions of anti-Semitism. ${ }^{57}$ This aggressive territorialism was a way of Irish-Americans attempting to align themselves with whiteness by distancing themselves from people that could be perceived as less-than-white.

In spite of the dominant position the Irish hold in American immigrant history, they occupy very little space in Hull-House materials. Hull House Maps and Papers almost never mentions them, except to differentiate them from the category of "Englishspeaking white" on the nationality map. "The Irish," they explain, "form so distinct and important an element in our politics and civil life that a separate representation [from 'white'] has been accorded them." 58 In the process of becoming the most ubiquitous, widespread of Chicago's immigrant groups, Irish-Americans undoubtedly gained a leg up in employment, housing, and the local political machine. But it also ironically cast them into a sort of invisible in-between space, where their saturation in the immigrant narrative eventually pushed them to the background. Irish-Americans became too American for their fellow immigrants, but remained too distinctly foreign to be considered part of the native "white" population, with all its attendant privileges.

\footnotetext{
${ }^{56}$ Patricia Kelleher, "Young Irish Workers: Class Implications of Men's and Women's Experiences in Gilded-Age Chicago," Eire-Ireland: A Journal of Irish Studies 36, no. 1 (2001): 162.

${ }^{57}$ Barrett and Roediger, "The Irish," 9-11.

${ }^{58}$ Hull-House Maps and Papers, 26-27; for more on the absence of Irish from HullHouse literature see Skerrett, "The Irish of Chicago's Hull-House Neighborhood."
} 
The Progressive Era's racial and color systems welcomed Italians into the category of whiteness more easily than the Irish (despite their generally darker complexions). No systemic forces of racial discrimination ever operated against Italians in Chicago-they were not affected by formal housing discrimination in the way African Americans were. But while they enjoyed the distinct advantages of whiteness, Italian Americans were also marked by "racial undesirability." 59 The Hull House studies noted that Italians (along with Polish and Russian Jews) usually occupied the rear tenements in the neighborhood - smaller "shanties" packed into the back of lots, presenting greater health and safety concerns. ${ }^{60}$

Italians in Chicago initially maintained a relatively comfortable relationship with African Americans. The Armour Square neighborhood, which bordered the Black Belt, remained a mixed Italian and African American neighborhood through 1919 with little conflict. But in the 1920s relationships between the two groups began to worsen as the lines of whiteness began to coalesce around those of European descent. Arrigo Park on the Near West Side became an embattled site between gangs of Italian and African American boys in the 1920 s and 1930s. ${ }^{61}$ European groups' attempts to physically distance themselves from African Americans were heightened by invigorated attempts at segregation in the 1920s. For example, the Chicago Real Estate Board sent speakers

${ }^{59}$ Guglielmo, White on Arrival, 9-29.

${ }^{60}$ Hull-House Maps and Papers also notes a tendency of other nationalities to move out upon arrival of Italians or Jews-although Nelli has challenged the accuracy of this assessment (Hull-House Maps and Papers, 18-19); for notes on housing conditions in the neighborhood and the rear tenements see "Chicago's Housing Conditions" and Walker, "Chicago Housing Conditions"; Guglielmo also notes instances of inter-ethnic informal housing discrimination in Guglielmo, White on Arrival, 25; 47.

${ }^{61}$ Guglielmo, White on Arrival, 45-49. 
throughout the city in 1927 , promoting restrictive housing covenants that particularly excluded African Americans. ${ }^{62}$

Mexican migrants presented a complex challenge to the era's racial constructs. Lighter-skinned Mexicans could "pass" as Spanish, identifying them with a European background. ${ }^{63}$ But unlike European immigrants, discrimination from multiple sides prevented the borders of whiteness from fully extending to encompass Latinos.

Democratic politicians emphasized the line between European "white" groups and Mexicans to try to appeal to European immigrants in their base. ${ }^{64}$ In the Back-of-theYards and South Chicago neighborhoods, Poles and Irish Americans had come to own much of the property, and either refused to rent to Mexicans, or price gouged them on rent. Some storekeepers also refused to extend credit to Mexican customers. ${ }^{65}$ Additionally, Polish and Irish gangs reportedly patrolled their neighborhoods, willing to employ violence to prevent Mexican men from crossing into their spaces. In 1927 a Mexican man was killed on Halsted Street, reportedly to "drive Mexicans out of the neighborhood." 66 Social workers noted that "in Chicago, the feuds between the Mexicans and Poles are well known."67

${ }^{62}$ Pacyga, Chicago, 224.

${ }^{63}$ Arredondo, Mexican Chicago, 134.

${ }^{64}$ Innis-Jimenéz, Steel Barrio, 54.

${ }^{65}$ Gabriela F. Arredondo, "Navigating Ethno-Racial Currents: Mexicans in Chicago, 1919-1939," Journal of Urban History 30, no. 3 (March 2004): 408-418; Sánchez, "Go After the Women," 288-292.

66 Arredondo, "Navigating," 403-406.

${ }^{67}$ Robert C. Jones and Louis R. Wilson, The Mexican in Chicago (Chicago, IL: Chicago Congregational Union, 1931), 19; see also Anita Edgar Jones, "Mexican Colonies in Chicago," Social Services Review 2, no. 4 (Dec 1928): 594-595. 
Mexican families in American urban settings remained highly insular, with a strong emphasis on mothers (and older girls) remaining within the privacy of the home. ${ }^{68}$ Some women performed wage work that they could do within the home, like laundering or taking in boarders, but the majority of men in Chicago opposed their wives taking any outside work. With an intensified focus on their place in the home, Mexican women came to be seen (both within and without their community) as the primary forces transmitting culture to the younger generation. They were less likely to attend English classes or social programs or clubs. This level of cloistering marked Mexican women as less likely to become "Americanized" and therefore, further from constructions of whiteness. ${ }^{69}$

Gabriela Arredondo writes that this prejudice inspired a distinct style of cultural pride among Mexicans in Chicago. Enactments of Mexicanidad in public spaces, through plays, parades, festivals, and sports, became a tool of pushing back against these experiences of exclusion and discrimination. ${ }^{70}$ Though it was also a heavily contested area, Bessemer Park in South Chicago was an important site for these performances, including Mexican Independence Day celebrations and Spanish-language plays. ${ }^{71}$ This was a way to assert their space in the city while also demonstrating pride in their home

${ }^{68}$ According to Sánchez, Chicago scholars have argued that the "stability and insularity of the Chicano family has acted as a fortress against alien cultural values," in Sánchez, "Go After the Women," 284-285.

${ }^{69}$ Sánchez, "Go After the Women,” 288-293; Innis-Jiménez, Steel Barrio, 88-91; Arredondo, Mexican Chicago, 122-125; Katrina Irving, Immigrant Mothers: Narratives of Race and Maternity, 1890-1925 (Champaign, IL: University of Illinois Pres, 2000), 1116.

${ }^{70}$ Arredondo, Mexican Chicago, 144-145; Innis-Jiménez, Steel Barrio, 11.

${ }^{71}$ Innis-Jiménez, Steel Barrio, 162-164. 
country, in spite of a hardening color line that increasingly defined whiteness around European identity.

\section{The Church and Immigrant Nationalisms}

Both the Catholic Church and the various immigrant communities in Chicago were divided along issues of nationalism. Irish and Polish groups built their national identities around Catholicism, so that proponents of national pride usually worked in conjunction with the Church. On the other hand, Mexicans and Italians came from countries that had developed secular nationalist movements in opposition to the Church. ${ }^{72}$ These communities experienced considerably greater friction with Church leaders and greater division within their own communities.

For most Irish immigrants, Catholicism and national identity were fundamentally intertwined. The famine in Ireland had led to a "devotional revolution"-a return to formal church practices, with a particular emphasis on the mass and the sacraments. It also elevated the importance of the priesthood, and prompted a new flood of Irish people entering religious orders. Irish children in America entered religious life at disproportionately higher rates than other groups. ${ }^{73}$ Certain revolutionary groups like Clan-na-Gael had drawn condemnation from archbishops in other cities, like Michael Corrigan in New York, but Archbishop Feehan had a friendly relationship with the group in Chicago, and even participated in some of its community projects. ${ }^{74}$

\footnotetext{
${ }^{72}$ Nelli, Italians, 188-189; Cohen, Making, 87-90; Badillo, Latinos, 23-25; Arredondo, Mexican Chicago, 17-20, 137.

${ }^{73}$ Barrett and Roediger, "The Irish" 19-21.

${ }^{74}$ Funchion, "Irish Chicago," 21.
} 
Polish immigrants demonstrated similar loyalty to the church, though specifically within their own national institutions. Like other immigrant groups, they resented the Irish domination of the American Church, and emphasized building up their own parishes around Polish identity. A certain body of exiles felt that independence efforts in Poland had failed due to structural weakness, so they sought to strengthen the community in America by building up its resources to the greatest extent possible. ${ }^{75}$ The Church and the associated parish schools served as a concrete connection to the homeland and the surest way of preserving Polish culture for the younger generation. The community also prioritized placing their children in Catholic schools-by the 1920s they had the highest rates of enrollment in the Catholic schools (about $60 \%$ of children ages seven to seventeen.$^{76}$

In 1873 a group of Polish priests, led by Reverend Barzynski, formed the Polish Roman Catholic Union, to unite the communities across the United States and to "preserve the Catholic faith and Polish heritage among the immigrants."77 The move was spearheaded by the Texas-based Resurrectionist Fathers (the most influential Polish American denomination), whose creed stated that "each Pole should retain his Catholic Faith, learn the language and history of Poland, but be given the chance to become a good

${ }^{75}$ Skok, More than Neighbors, 12; Radziłowski, Eagle, 2-3.

${ }^{76}$ Cohen, Making, 85-87; Kantowicz, "Polish Chicago," 186-189; Shanabruch, Chicago's Catholics, 121.

${ }^{77}$ Kantowicz, Polish-American Politics, 10; for more on the PRCU, see Radziłowski, Eagle. 
Yankee."78 The Union helped establish schools, hospitals, orphanages, and seminaries in addition to churches. ${ }^{79}$

For the most part, Catholicism was a central element of the Polish American experience, although a few nationalist groups battled with the Church for influence. Some nationalists in Chicago accused Reverend Barzynski of elevating religion over Polish identity. ${ }^{80}$ The Polish National Alliance was one organization that didn't define itself around Catholicism. Generally critical of the Church, it also accepted Polish Jews and nonbelievers, prioritizing national Polish politics over matters of religion. Whereas the Polish Roman Catholic Union was focused on maintaining the faith among Polish Americans and nurturing Polish American culture, the PNA wanted immigrants to Americanize faster, and believed this should be accomplished by breaking their loyalty to the Church. ${ }^{81}$ St. Stanislaus Kostka helped found Chicago's first Polish-language daily newspaper, Dziennik Chicagoski, partly to fire back at anticlerical and socialist publications funded by such groups. ${ }^{82}$

Whatever nationalist/religious divide existed within the Polish community was far more pronounced in the Italian and Mexican communities, in which nationalist movements had grown in direct opposition to the Catholic Church. Additionally, the Mexicans and Italians practiced a folk style of Catholicism that clashed with the

\footnotetext{
${ }^{78}$ Kantowicz, Polish-American Politics, 32.

${ }^{79}$ Radziłowski, Eagle, 2-3.

${ }^{80}$ Greene, "Becoming," 156.

${ }^{81}$ Shanabruch, Chicago's Catholics, 93-95.

${ }^{82}$ Kantowicz, Polish-American Politics, 32-41.
} 
formality of the Irish-dominated clergy. Both cultures demonstrated a distance from the Church and its offices, a greater tendency towards popular expressions of devotion, and stronger engagement with religion among women than men. ${ }^{83}$

For Italian Americans, the traditions of their home village took greater precedence in their religious expression than either the clergy or the Church. In fact, many Italians in Chicago did not attend church at all. Italian peasant Catholicism centered around the festa, or the celebration of an individual community's patron saint. During the festa, the men of the neighborhood carried statues of the Madonna or other saints through the neighborhood, sometimes pinning money or throwing jewelry on the statue to ask for favors. In Italy, these celebrations represented unity between the local church and the village by physically bringing the statue out of the church and into the community. But in America many Italians felt alienated from the Irish-dominated Church, so the festa recentered religion in their own space, among their own people. Many members of the clergy viewed these celebrations (which were not sanctioned by the Church) with suspicion. Traditional leaders condemned the processions as overly indulgent, superstitious, or idolatrous. As a form of worship over which the priests had no control, the celebrations challenged the control that Irish clergy held over the American Church. ${ }^{84}$

${ }^{83}$ Badillo, Latinos, 40-43, 145; Lindley, You Have Stept, 202-205; Linkh, American Catholicism, 39-43; Nelli, Italians, 189; Cohen, Making, 88-90; Jackson, Lines of Activity, 52.

${ }^{84}$ Cohen, Making, 87-90; Barrett and Roediger, "The Irish," 21; Skok, More than Neighbors, 85; Nelli, Italians, 189; Robert E. Park and Herbert A. Miller, Old World Traits Transplanted (New York, NY: Harper and Brothers Publishers, 1921), 155. 
Priests translated this discomfort with Italian forms of popular worship into complaints that Italian parishioners were ignorant, rarely showed up to mass, or didn't receive communion often enough. ${ }^{85}$ The gendered patterns of devotion in Italian American communities also concerned the clergy, as women attended church far more often than men. Priests claimed that Italian men only attended church for baptisms, weddings, and funerals, and complained that their children were ignorant of Catholic doctrine. ${ }^{86}$ Italian Catholics chafed under the traditionalist leadership of the Irish American church, enough that their frustrations sometimes bridged the divide between Catholics and liberals in the community. ${ }^{87}$

However, opposition to the Irish domination of the Church in America also had the potential to worsen tensions between Italian Catholics and nationalists. Italian nationalism and the Catholic Church acted as "opposing forces," as nationalists in Italy opposed the entrenched power of the Church, generating a strong vein of anti-clerical socialism. ${ }^{88}$ In the American context, the added factor of the tension between Italian Catholics and the Irish leadership made the Church appear doubly oppressive to nationalists.

Alessandro Mastro-Valerio, a dedicated nationalist, demonstrated the complex feelings of some immigrants towards the Church. He considered himself a "good

${ }^{85}$ Nelli, Italians, 181-183; Brown, “Making," 217; Linkh, American Catholicism, 37-41; Shanabruch, Chicago's Catholics, 125.

${ }^{86}$ Lindley, You Have Stept, 203; Linkh, American Catholicism, 40.

${ }^{87}$ Nelli, Italians, 178.

${ }^{88}$ Barrett and Roediger, "The Irish," 20; Nelli, Italians, 188. 
Catholic" and was allegedly "shocked and insulted" by accusations to the contrary. ${ }^{89}$ But Mastro-Valerio was also an outspoken critic of the Church. He owned La Tribuna Italiana, one of the biggest Italian-language newspapers, with readership well beyond Chicago, which he used as a vehicle for criticizing and supporting labor movements among Italian workers. ${ }^{90}$ He also helped found the Giordano Bruno Club, which purportedly "affirmed the authority of the Church in spiritual matters" but was opposed to its political power. ${ }^{91}$ Despite the mission statement, some members of the Club expressed an explicit desire to draw fellow immigrants away from the Church. ${ }^{92}$ Anticlerical Italians were especially unhappy with the appointment of Father Edmund Dunne as pastor of Holy Guardian Angel Church and Mission, since he was Irish and it was an Italian parish. ${ }^{93}$ In turn, Father Dunne was a vocal critic of the Club and its activities.

Father Dunne also did not miss the close relationship Mastro-Valerio had with the Hull-House, and the house's willingness to open their doors to the Club's message. Mastro-Valerio was involved with several of Hull-House's Italian-oriented projects in its early years, including giving lectures, teaching Italian language classes, and serving on the reception committee for parties for the Italian community. He was even listed on the Hull-House roster under "Authors and Journalists." 94 The Club staged two plays at the

${ }^{89}$ Skok, More than Neighbors, 78.

${ }^{90}$ Nelli, Italians, 158-161, 188.

${ }^{91}$ Shanabruch, Chicago's Catholics, 135.

92 Skok, More than Neighbors, 79-80; Lissak, Pluralism and Progressives, 97.

93 Barrett and Roediger, "The Irish," 20.

${ }^{94}$ List of Residents, box 32, folder 294, Hull-House Collection; Hull-House Yearbook 1913, box 44, folder 436, Hull-House Collection. 
Hull-House theater with blatant anti-clerical themes-first in 1908 and again in 1913drawing condemnation from Chicago's Catholic leaders. ${ }^{95}$

A similar dynamic played out in the Mexican community around nationalism, religion, and the Hull-House. For Mexican immigrants, processions and public displays of worship were also important, but religion was even more centered around women, the family, and the home. Home altars, prayers, and the religious instruction of children, as well as an emphasis on Marian imagery, positioned women as the main conduits of faith in the family and the community. ${ }^{96}$ When it came to the Church, women were the primary attendees. A Chicago man named Ramon recalled that he was "raised with the cultural idea that 'males were not supposed to be too close to religion."' His mother regularly attended church, but he and his father almost never did. ${ }^{97}$

The revolutionary upheaval in Mexico at the beginning of the century also translated into a rift in the community between secular nationalist and Catholic groups. In 1928 Cristero sympathizers in Chicago formed the Union Nationalista Mexicana-and the same year, the Mexican Masonic Lodge was formed as an opposing force. Catholics also clashed with the socialist group El Frente Popular when it came to Chicago in 1935. Representatives of El Frente travelled to Chicago from Mexico to "spread the message of radical worker solidarity." The group worked primarily out of the University of Chicago

95 Shanabruch, Chicago's Catholics, 135.

${ }^{96}$ Badillo, Latinos, xiii-Xv, 131-145.

${ }^{97}$ Badillo, Latinos, 131; see also Cyprian, "The Hispanic Catholics.” 
Settlement and Hull-House, as they were two popular gathering places for the Mexican community. ${ }^{98}$

A year later, a woman named Mrs. de la Mora approached Adena Miller Rich (the head resident of Hull-House in 1936) to express her concerns about El Frente, its attempts to raise money within the Mexican community, and its potential to alienate conservative Mexican groups meeting at the house. Hull-House residents debated over whether to allow the group to continue meeting at the settlement, and finally decided they would continue to rent a room to El Frente, rather than allowing them to gather there for free (as they worried it would appear to be an endorsement of the group's activities). The same year, Hull-House hosted a debate between a member of El Frente, Don Rafael Perez, and an opposing member of the community, Don de la Mora, over whether the group was actually benefitting the economic and cultural interests of the Mexican immigrant community.

While the debate represented a deep cultural and ideological divide between conservative Catholics and socialists, the rift was apparently not insurmountable. Representing the immigrant community's use of public celebrations to embody a united presence in the city, Mrs. de la Mora suggested to Adena Miller Rich that they hold a fiesta to help unite the various elements of the community across their political and religious differences. Soon after, Hull-House collaborated with several local Mexican

98 Arredondo, Mexican Chicago, 136-137, 162. 
clubs to host a massive, well-publicized "Mexican Fiesta," including dances and a play about the history of Mexico. ${ }^{99}$

These kinds of political, national, and gendered rifts set the stage for tension between Hull-House reformers and the Catholic Church as they each worked to establish their space in the city. The communities that distanced themselves from the formal Church became the main priority of Catholic settlement houses. Settlement workers on both sides also sought to make inroads into the home lives of immigrant mothers, establishing their authority via their purported expertise in areas of childrearing and household care. The challenges between the Hull-House and Chicago's Catholic Church played out more in the public sphere, while the subtler contestations for space between the two groups of settlement women crossed the line into the private sphere of women and children's lives.

99 The events surrounding El Frente Popular and the Mexican Fiesta at Hull-House are detailed in Halsted's Mexican American Community and Hull House 1934-1937, box 1, folder 11, Adena Miller Rich Papers, Special Collections and University Archives, University of Illinois at Chicago. 
Chapter 2 - Contestation for Space and Influence

Demarcations of public and private lives (often built around privatizing women and children within the home space) were not the only lines to be blurred in this period. As poverty dominated wide sections of the city and the racial and ethnic demographics were in constant flux, Progressive-era Chicago became an environment marked by instability, wherein these different groups-Hull-House reformers, Catholic women, and Catholic immigrants-jostled for space. For Hull-House women, this meant both having a physical and visible presence in the neighborhood, and amplifying women's voices and capacity for influence in the public sphere. Though Addams and other settlement workers characterized the settlement house as a new venture that filled unmet needs in the city, Catholic organizations already had an established presence among their impoverished communities, and a vested interest in keeping the care of children and the protection of women within the circle of family and private organizations. Besides the churches, these included many St. Vincent de Paul societies; the Catholic Visitation and Aid Society, which worked to place abandoned children in Catholic homes or institutions; and West Side’s Magdalen Asylum for delinquent girls, which had been operating since $1867 .{ }^{1}$ Even Hull Mansion had briefly been used as a home for the elderly by the Little Sisters of the Poor before Addams and Starr purchased it. ${ }^{2}$ If their venture was to succeed, Hull-

\footnotetext{
${ }^{1}$ Ellen Skerrett, Edward R. Kantowicz, and Steven M. Avella, Catholicism, Chicago Style (Chicago, IL: Loyola University Press, 1993), 14-15; Suellen Hoy, "Caring for Chicago's Women and Girls: The Sisters of the Good Shepherd, 1859-1911," Journal of Urban History 23, no. 3 (March 1997): 260-282.

${ }^{2}$ Ellen Skerrett, "Irish of Chicago's Hull House Neighborhood," in New Perspectives of the Irish Diaspora, ed. Charles Fanning (Carbondale, IL: Southern Illinois Press, 2000), 212.
} 
House women had to establish themselves as an institution that filled unique needs not already being met by private religious organizations. ${ }^{3}$

Catholic laywomen, on the other hand, faced the task of having to carve out space for themselves in between the male leaders, already-established organizations of religious sisters, and the city's secular organizations. In order to gain funding and even physical space for their work, Catholic laywomen had to establish and defend the value of their work within a religious hierarchy that had rendered them largely invisible. Middle-class Catholic women had sodalities and club organizations similar to other middle-class women, but they usually operated as auxiliaries to more formal church operations. Women's work that didn't seek appropriate approval from Church leaders could draw condemnation from priests. ${ }^{4}$

Hull-House and Chicago's Catholic institutions had similar approaches and at times collaborated on issues-such as when Addams and Father Edmund Dunne worked

\footnotetext{
${ }^{3}$ A quote from the National Federation of Settlements: "It still remains true that there is no place to which a group of boys and girls desiring to associate themselves as a club can find hospitality except in the neighborhood houses. Neither the private schools nor the churches nor any other of the community institutions, semi-public or private, have set out to meet this simple but fundamental need of youth." National Federation of Settlements 1932, box 55, folder 670, Hull-House Collection, Special Collections and University Archives, University of Illinois at Chicago.

${ }^{4}$ Dorothy M. Brown and Elizabeth McKeown, The Poor Belong to Us: Catholic Charities and American Welfare (Cambridge, MA: Harvard University Press, 1997), 7, 72-76; Deirdre M. Moloney, American Catholic Lay Groups and Transatlantic Social Reform in the Progressive Era (Chapel Hill, NC: University of North Carolina Press, 2002), 7-10; Debora A. Skok, More than Neighbors: Catholic Settlements and Day Nurseries in Chicago, 1893-1930 (Dekalb, IL: Northern Illinois University Press, 2007), 8-9; Kathleen Sprows Cummings, New Women of the Old Faith: Gender and American Catholicism in the Progressive Era (Chapel Hill, NC: University of North Carolina Press, 2009), 48.
} 
together to advocate for more public parks in the neighborhood. ${ }^{5}$ Where they disagreed was over approaching social issues from a religious-moral framework, or from a secular, pragmatist standpoint. This conflict usually took the form of explicitly political issues when Hull-House clashed with church leaders-especially around socialism and the labor movement. But conflict between Hull-House and Catholic laywomen in Chicago centered on issues of motherhood, childhood, and the home. These were areas where women were taken seriously as professionals and considered to have some authority. ${ }^{6}$ Motherhood and child welfare were contested areas because they formed the bases for each of these groups of women to carve out their respective spaces in Chicago's evolving socialpolitical landscape.

\section{The Divide in Religious and Secular Methodologies}

While working towards similar goals, Hull-House settlement workers and Catholic organizations approached the problems of the city through different frameworks. Catholic workers placed faith and the Church's teachings at the center of their work, while Hull-House emphasized a vision of democratic pluralism which refused to elevate one creed over another. Therefore, it approached problems through a more pragmatic lens. The 1911 Handbook of Settlements defined a settlement house as a "wholly

\footnotetext{
${ }^{5}$ Hull-House Bulletin Mid-Winter 1903-04, box 43, folder 431, Hull-House Collection. ${ }^{6}$ See Robyn Muncy, Creating a Female Dominion in American Reform 1890-1935 (New York, NY: Oxford University Press, 1991), xv, 20.
} 
unsectarian" organization that "provides neutral territory traversing all lines of racial and religious cleavage."7

Meanwhile, Catholic settlement and charity workers viewed this approach as fundamentally lacking because it was not guided by the wisdom of religion. From their perspective, when settlement workers chose to help people, they did so out of concern for the general public welfare, but not out of a sense of loving duty to individuals as fellow children of God. ${ }^{8}$ Teresa O’Donohue, a prominent worker with Catholic Charities, wrote that secular settlements "supply the immediate wants of poor and ignorant children, but ignore the sublime dignity and eternal destiny of the child." ${ }^{, 9}$ Mary Amberg also criticized the secular and materialist values of Hull-House in comparison to the sacred purpose of the Catholic settlement houses. According to Amberg, the Catholic Church's version of the social gospel could equal and even surpass anything those outside the Church had to offer. $^{10}$

The secular position wasn't just inadequate, but threatening to the spiritual lives of Catholic immigrants. Because the Church framed morality as originating from religion, they implied that the absence of spirituality at Hull-House made it "morally

\footnotetext{
${ }^{7}$ Robert A. Woods and Albert J. Kennedy, Handbook of Settlements (New York, NY: The Russell Sage Foundation, 1911), v.

8 "A Religious Community of Professional Settlement Workers," Catholic Charities Review 5, no. 4 (April 1921): 124.

9 Teresa R. O'Donohue, “The Association of Catholic Charities," Catholic Charities Review 2, no. 7 (September 1918): 248.

${ }^{10}$ Mary Amberg, Madonna Center: Pioneer Catholic Settlement (Chicago, IL: Loyola University Press, 1976), 45, 83-84; Moloney, American Catholic Lay Groups, 151.
} 
bankrupt." "11 The greatest fear, among both Church leaders and layworkers, was that social settlements stood to lure immigrants away from the Church. Amberg claimed that Hull-House and the Chicago Commons "could be and in fact were dangerous to our Catholic Italian Americans," who would have "sold their Roman Catholic birthright for a mess of proselytizers' and humanists' pottage." ${ }^{12}$ Chicago's Archdiocesan newspaper New World called Hull-House a "competitor for the souls of Italian children." 13 And Reverend James B. Curry, in a speech before the First American Catholic Missionary Congress, called the influence of the settlement houses "non-Catholic, if not positively anti-Catholic." ${ }^{14}$ Suspicions of Hull-House alternated between characterizing it as a breeding ground for socialists and anarchists, to those who believed it was operating covertly as a Protestant evangelizing center. ${ }^{15}$ Either way, by locating settlements in the center of major Catholic immigrant populations, priests felt that settlement workers were challenging the Church's right to their own people. ${ }^{16}$

${ }^{11}$ Charles Shanabruch, Chicago's Catholics: The Evolution of an American Identity (Notre Dame, IN: University of Notre Dame Press, 1981), 134.

12 Amberg, Madonna Center, 39.

${ }^{13}$ Quoted in Rivka Shpak Lissak, Pluralism and Progressives: Hull House and the New Immigrants, 1890-1919 (Chicago, IL: University of Chicago Press, 1989), 97.

${ }^{14}$ James B. Curry, "Settlement Work," in The First American Catholic Missionary Congress, ed. Francis C. Kelley (Chicago, IL: J.S. Hyland and Company, 1908), 159.

${ }^{15}$ Curry claimed that the "working force" behind all settlement houses was Protestant even if they outwardly rejected any church affiliations, Curry, "Settlement Work," 159; Father Edmund Dunne of Chicago accused Hull-House of being "partial to socialists and anarchists" in "Clerical Clash Given Pro and Con," Chicago Tribune, Mar 1, 1908; The Catholic Charities Review also referred to social workers as propagandists of Socialism, Bolshevism, and birth control in "A Religious Community of Professional Social Workers," Catholic Charities Review, 124.

${ }^{16}$ R.A. McEachen, "Our Five Million Immigrants," in The First American Catholic Missionary Congress, ed. Francis C. Kelley (Chicago, IL: J.S. Hyland and Company, 1908), 274; P.J. Muldoon, "Immigration to and the Immigrants in the United States," in 
Hull-House residents also pushed back against such accusations with their own critiques. They claimed that the Church did not involve itself enough in people's lives, and that they could not build meaningful relationships with working-class people because the relationships were always predicated on trying to convert people or mold them to a certain dogma. ${ }^{17}$ Additionally, Addams felt that churches-along with other "moralists" and teachers of the city-had failed to adequately pass on a moral code to young people. She pointed out that over 15,000 youth had been arrested in one year in Chicago, and claimed that all of them had "been subjected to some sort of religious instruction." 18

Addams's assertions that the Church remained aloof from working people's lives demonstrates an obvious blindness to the masses of working-class Catholics that had labored to build up the Church in the preceding two decades. On the one hand, Addams had developed early on a worldview that pitted creed or dogma against meaningful social action. ${ }^{19}$ The settlement movement, as well, constantly distinguished itself from charity and the "mission method." ${ }^{20}$ Operating under the belief that religious doctrine was

Official Report of the Second American Catholic Missionary Congress (Chicago, IL: J.S. Hyland \& Co., 1914), 138-143; see also Moloney, American Catholic Lay Groups, 6, 118.

17 This was an attitude Addams and Starr seemed to hold about churches in general, not just the Catholic Church. See National Federation of Settlements 1932, box 55, folder 670, Hull-House Collection; "The Church and the Social Problem", September 25, 1901, Jane Addams Papers, https://digital.janeaddams.ramapo.edu/items/show/6864, 145-152.

18 “The Reaction of Modern Life Upon Religious Education," February 11, 1910, Jane Addams Papers, https://digital.janeaddams.ramapo.edu/items/show/4957, 23.

${ }^{19}$ See Jane Addams, Twenty Years at Hull-House with Autobiographical Notes (New York, NY: The MacMillan Company, 1911), 119-122.

${ }^{20}$ Addams, "The Church and the Social Problem," 146; Gaylord S. White, "The Settlement Problem of a Changing Neighborhood," (1910) in Readings in the Development of Settlement Work (New York, NY: Association Press, 1950), 91; Samuel A. Barnett, "Education by Permeation" (1906), in Readings in the Development of 
anathema to her brand of social work likely blinded Addams to the influence of the Catholic Church among many of her neighbors. Yet her claims also laid out an image of the Church's shortcomings in order to establish the necessity of the social settlements. In Addams's words, Hull-House wasn't just adding itself to a list of already-present institutions working in the city-it was stepping into a vacancy left by the Church's supposed unwillingness to be involved in personal acquaintance with the working poor. "Fortunately, for thousands of these young people whom the Church has not successfully shepherded," she wrote in a 1910 article, "other forces... are reducing creed to action and are making a high demand upon their ardor and their desire for altruistic action." 21

Ellen Gates Starr, Hull-House's less-famous founder, shared many of these critiques despite her fondness for the Church and eventual conversion to Catholicism. Though Starr was more religious than Addams, she also adopted explicitly political stances. During her years as a public reformer, Starr was active in the labor movement and an outspoken advocate of socialism. ${ }^{22}$ She often conflated Christian/Catholic values with socialist values, and in 1896 wrote that the "fundamental Christian doctrine of brotherhood" was being taught more effectively through the labor movement than

Settlement Work, ed. Lorene M. Pacey (New York, NY: Association Press, 1950), 82; Elisabeth Lasch-Quinn, Black Neighbors: Race and the Limits of Reform in the American Settlement Movement, 1890-1945, (Chapel Hill, NC: University of North Carolina Press, 1993), 50-52.

${ }^{21}$ Addams, "The Reaction of Modern Life," 27.

${ }^{22}$ Allen F. Davis, Spearheads for Reform: The Social Settlements and the Progressive Movement 1890-1914 (New York, NY: Oxford University Press, 1967), 121. 
through the churches. ${ }^{23}$ She criticized the Church for hindering the goals of "secular justice" by their lack of support for the labor movement. Though Starr participated actively in Catholic services, she felt that "the social result for which we are working in settlements can not, at this day, be achieved with the Church so well as without her." 24

It was this support of socialism and organized labor that most often caused HullHouse to clash with Chicago's Catholic leaders. Though Hull-House claimed not to support any one economic theory, members like Ellen Gates Starr and Florence Kelley were ardent socialists, and the house was not shy about supporting labor unions. Many unions and organizations sympathetic to labor met regularly at the house. It became a valuable location for female union members that struggled to assert themselves in the male-dominated union halls. ${ }^{25}$ Hull-House also expressed support for the garment workers' strike in 1896, and again in 1910, when Jane Addams helped raise money for coal and food for the striking workers. ${ }^{26}$ Starr was even arrested for participating in a waitresses' strike in 1914, after which Addams and Mrs. Bowen called a meeting at Hull-

${ }^{23}$ Ellen Gates Starr, "Settlements and the Church's Duty," (1896) in On Art, Labor, and Religion, eds. Mary Jo Deegan and Ana-Maria Wahl (New Brunswick, NJ: Transaction Publishers, 2003), 152.

${ }^{24}$ Starr, "Settlements," 154; for more on Ellen Gates Starr's conversion to Catholicism, see Ellen Gates Starr, "A Bypath into the Great Roadway," (1924) in On Art, Labor, and Religion, eds. Mary Jo Deegan and Ana-Maria Wahl (New Brunswick, NJ: Transaction Publishers, 2003):168 - 176; Suellen Hoy, Ellen Gates Starr: Her Later Years (Chicago, IL: Chicago History Museum, 2010).

${ }^{25}$ Mina Carson, Settlement Folk: Social Thought and the American Settlement Movement, 1885-1930 (Chicago, IL: The University of Chicago Press, 1990), 77-83.

${ }^{26}$ Hull-House Bulletin May 1896, box 43, folder 425, Hull-House Collection; Hilda Satt Polachek, I Came a Stranger: The Story of a Hull-House Girl, ed. Dena J. Polachek Epstein (Urbana, IL: University of Illinois Press, 1989), 121. 
House to "suggest measures for investigating the conduct of the police" against the strikers. $^{27}$

But the most contentious issues were when groups that met at the house exacerbated the nationalist/religious split within immigrant Catholic communities. The previously-mentioned Giordano Bruno Club was the most controversial presence at HullHouse for Chicago's Catholic leaders. The tension over the Club came to a head in March 1908 when threats were made against several priests in Chicago, following an attack on a priest in Denver by an anarchist named Giuseppe Alio. When the churches in Chicago publicly denounced the Giordano Bruno Club (suspecting it as the origin of the threats), Addams defended it, igniting a brief conflict with Chancellor Edmund Dunne. She described the Club as an Italian political party "committed to the separation of church and state" and claimed that it contained many Catholics. ${ }^{28}$ Dunne in turn accused her of being ignorant of Mastro-Valerio's attacks on the Church, expressed mostly through his Italianlanguage newspaper La Tribuna Italiana, and "intimated that Hull-House is partial to socialists and anarchists.",29

These high-visibility tensions hid the subtle contests for space and influence that played out between Hull-House women and Catholic laywomen. The welfare of women and children, which formed the basis of female reformers' work in the Progressive Era,

${ }^{27}$ Ellen Gates Starr, "Efforts to Standardize Chicago Restaurants-The Henrici Strike," The Survey 32 (1914): 214-215.

28 "Clerical Clash," Chicago Tribune, Mar 1, 1908; "Police at Masses," Chicago Tribune, Mar 1, 1908.

29 “Clerical Clash,” Chicago Tribune, Mar 1, 1908. 
also became the main sticking point between these two groups of women. In Chicago, these contests occurred in the arenas of home visiting, the struggle between public and parish schools, and the controversy over birth control.

\section{Motherhood and Childhood as Contested Areas}

Hull-House residents' position of themselves as experts vis-à-vis their residence in the neighborhood and investigations into the lives of the poor, gave them a platform for public advocacy that later evolved into the profession of social work. But their attention to the lives of women and children of the Near West Side had a special efficacy in pushing for greater rights and visibility for women overall. Hull-House reformers used their role of speaking on behalf of poor women to advocate for greater government involvement specifically guided by increased women's participation. To this end, residents emphasized the fact that women's lives did not exist in a separate realm from political issues-that poor women suffered from bad municipal policies but remained helpless to change them within the confines of the domestic sphere. In a speech advocating for suffrage, Jane Addams wrote that "woman is the one above all who suffers in her home from bad city housekeeping. She is the one who suffers when the streets are dirty and when vermin, through no fault of hers, infect a district." ${ }^{30}$ Women and children were essentially placed in a state of dependence on city government when it came to the cleanliness of their home environments, the quality of their food and milk, and the state of the education system. In other words, mothers' ability to care for their

\footnotetext{
${ }^{30}$ Addams, "The Social Value of the Immigrant," March 14, 1908, Jane Addams Papers, https://digital.janeaddams.ramapo.edu/items/show/9293.
} 
children properly was one of the first casualties of poor or insufficient policies. ${ }^{31}$ For Hull-House women, this was evidenced by incidents like the 1902 typhoid outbreak in the Nineteenth Ward, caused by infestations of flies due to built-up garbage that the city was failing to haul away. ${ }^{32}$ Hull-House women took these issues seriously and actively looked for ways to improve their neighborhood. But this framing of poor women as dependents was simultaneously vital to Hull-House women advancing their interests and justifying their entrance into what they felt was meaningful work.

Catholic laywomen, alternatively, worked within a hierarchy that already had an established model of female public service though orders of religious sisters. Laywomen in this period felt pushed to adopt emerging models of social work to protect the vitality and autonomy of their faith community. They especially pushed back against increased government intervention in church institutions, which was often hostile to Catholic interests, and which Hull-House residents actively championed. ${ }^{33}$

Yet Catholic women, operating within the Church hierarchy, fell in-between the male clergy and the religious sisters in a way that made it difficult for them to stake out space for their work. As Madonna Center evolved from the Sunday School association to Guardian Angels Mission to its final stage as a settlement house, every step required the approval and provision of the clergy. The original founders had to appeal to Archbishop

${ }^{31}$ See Addams, "Woman's Conscience and Social Amelioration," 41-42, Jane Addams Papers, https://digital.janeaddams.ramapo.edu/items/show/6947.

32 Referenced in Hull-House Yearbook 1913, box 44, folder 436, Hull-House Collection.

${ }^{33}$ For examples of government policies hostile to the Church, see Shanabruch, Chicago's Catholics, 60-66; Hoy, "Caring," 281; Brown and McKeown, Poor Belong to Us, 13-59. 
Feehan to begin the Sunday School Association; their initial rooms at the School of the Guardian Angel were "kindly placed at their disposal by the Jesuit Fathers." ${ }^{\text {"T }}$ They operated out of the shuttered St. Francis of Assisi school for a time, until Cardinal Mundelein decided to reopen the school, and in 1917 the Center suddenly found itself having to adjust to a few rooms in an abandoned storefront on Polk street. Mary Amberg wrote in her memoir that being kicked out of the St. Francis of Assisi school felt

summary and unfair, but as loyal sheep of the flock we set out to obey the pastoral order. Our friends and supporters who felt we were not being fairly dealt with asked us to make representations to the archbishop. But this sort of reaction was contrary to mother's concept of Christian meekness and obedience. ${ }^{35}$

Being dependent on the Church for support and funding meant that laywomen had to simultaneously demonstrate that their work was new-distinct from the work of the sisters-while also clarifying that it remained within the bounds of respectable female roles. Even so, their efforts tended to earn a backlash when they were perceived as challenging male leaders' authority as the main guardians of the welfare of families within their parish. ${ }^{36}$

Catholic laywomen and Hull-House workers had similar approaches to the welfare of women and children in Chicago. Mothers' Clubs, day nurseries, infant welfare

\footnotetext{
${ }^{34}$ Christ-Child Society of Chicago 1915-1916, Madonna Center Records, series 1, box 2, folder 7, Mary Agnes Amberg Papers, Special Collections and University Archives, Marquette University.

35 Amberg, Madonna Center, 100.

${ }^{36}$ Brown and McKeown, Poor Belong to Us, 5-7, 72-89; Moloney, American Catholic Lay Groups, 9-10; Skok, More than Neighbors, 9.
} 
clinics, and recreational activities for children were a mainstay of the settlements. But when these groups of women had conflicting views over subjects that impacted women and children, it was more than just a difference of opinion or methodology. Home visiting, the schools, and the issue of birth control became sites of challenges for influence because they stood to either strengthen or undermine the spaces that these women had established for themselves within their respective social landscapes.

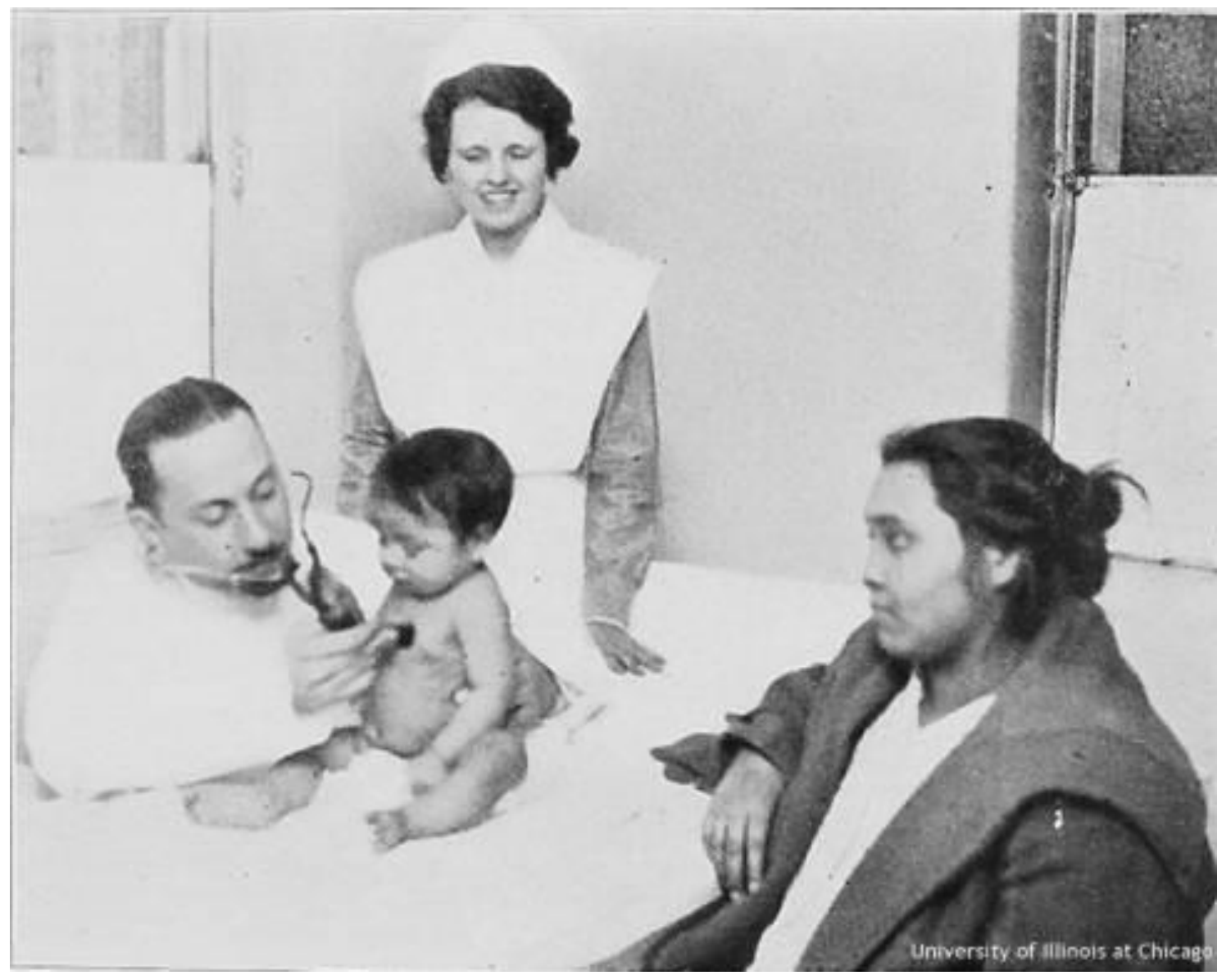

“A Clinic-Infant Welfare Society (1927).” 440-5644, Hull-House yearbook photos, Special Collections and University Archives, University of Illinois at Chicago. Photograph reproduced with permission of University Archives. 
Friendly Visiting as a Claim to Home Spaces

The practice of home visiting, or friendly visiting, was an established method among charities in Chicago, both religious and secular, by the end of the nineteenth century. Charity workers had come to rely on gaining entrance into the homes of poor families as an effective means of dispensing services or gathering information on urban conditions. Friendly visiting could take on several different forms-nurses or volunteers might visit the sick in their own homes, or teachers could visit children who were too sick to attend school. ${ }^{37}$

The type of home visiting conducted by Hull-House residents was often driven by government initiatives, and reinforced their position as experts in the community. The information published in Hull House Maps and Papers was based on data residents gathered for the US Department of Labor's Special Investigation into the Slums of Great Cities. ${ }^{38}$ Hull House residents also conducted research under the auspices of the Department of Agriculture, the Immigration Commission, the Children's Bureau, and other federal departments. ${ }^{39}$ Sophonisba Breckinridge's “Americanization Study” included extensive interviews that she conducted with Italian immigrant families in their homes. Residents conducted thorough investigations on the housing conditions in the

${ }^{37}$ Hull-House Bulletin Mid-Winter 1903-04, box 43, folder 431, Hull-House Collection; Carson, Settlement Folk, 73-74.

${ }^{38}$ Hull House Maps and Papers (New York, NY: Thomas Y. Crowell \& Company, 1895), 6.

${ }^{39}$ Woods and Kennedy, 53-64; Addams, Twenty Years, 129; Sophonisba P. Breckinridge, New Homes for Old (New York, NY: Harper and Brothers, 1921), 62. 
neighborhood and their implications for the health and safety of children. ${ }^{40}$ The findings were often bleak-in 1912 Jane Addams observed to a settlement conference that only 10 to $25 \%$ of girls in the community were living in households that met their standards of an "adequate home." ${ }^{41}$ Hull-House residents appealed to government authorities to condemn dangerous or inadequate housing, enforce health standards, and/or oversee the construction of better housing. ${ }^{42}$

Both Catholic and secular settlement workers also utilized another form of friendly visiting focused on advising poor, immigrant mothers on housekeeping and childrearing. ${ }^{43}$ Chicago settlement workers in this period agreed that the home was vital to the formation of individuals and children, and that a home environment which fell short of their standards of cleanliness and respectability was a detriment to not just the

${ }^{40}$ For example, after discovering high rates of child mortality in the neighborhood, members of the Woman's Club divided the ward into sections, and "three times every week certain women went through each section in order to find out what could be done to make the territory clean." Within three years the ward saw a significant drop in mortality rates of children under five. "Woman's Conscience and Social Amelioration," 49-50, Jane Addams Papers, https://digital.janeaddams.ramapo.edu/items/show/6947.

${ }^{41}$ Addams, "The Child at the Point of Greatest Pressure," June 16, 1912, 27, Jane Addams Papers, https://digital.janeaddams.ramapo.edu/items/show/7934.

42 Jane Addams, "The Housing Problem in Chicago," The Annals of the American Academy of Political and Social Sciences 20 (1902): 101; "Chicago Housing Conditions," 296; Breckinridge, New Homes, 80-82.

${ }^{43}$ See Frances A. Kellor, "Neighborhood Americanization: A Discussion of the Alien in a New Country and of the Native American in His Home Country" (address delivered at the Colony Club, New York, NY, February 8, 1918), https://babel.hathitrust.org/cgi/pt?id=mdp.39015057101472\&view=1up\&seq=1; George J. Sánchez, “'Go After the Women:' Americanization and the Mexican Immigrant Woman, 1915-1929" in Unequal Sisters: A Multicultural Reader in U.S. Women's History, eds. Vicki L. Ruiz and Ellen Carol DuBois (New York, NY: Routledge, 1994), 291; Katrina Irving, Immigrant Mothers: Narratives of Race and Maternity, 1890-1925 (Champaign, IL: University of Illinois Press), 73-82. 
family, but the greater society. ${ }^{44}$ Additionally, they agreed that many immigrant mothers lacked sufficient information or training on the standards of a healthy, wholesome home, and were unlikely to get it from friends and neighbors. ${ }^{45}$ Therefore, educated women formed groups to bring instructions on cooking, cleaning, and childcare into poor women's homes.

The Madonna Center's 1916 report included 1,115 instances of “friendly visits and relief investigations." ${ }^{46}$ They had an official "friendly visitor" and employed a visiting nurse, Miss Mack, who would follow up on hygiene lessons being taught to kindergarteners, and make sure they were being followed in the home. For families seeking assistance, volunteers from the Center would visit the homes to investigate if the family seemed to meet their qualifications of poverty. ${ }^{47}$ Prominent Catholic settlements in other parts of the country also prioritized home visiting. The Margaret Barry House in Minneapolis employed a visiting nurse who instructed mothers in sanitation, feeding, and caring for babies. And St. Elizabeth Settlement in St. Louis felt that "one of the greatest needs of persons in poverty is encouragement and advice," referring to ninety-nine home

\footnotetext{
${ }^{44}$ A Catholic Charities Review article in 1921 described the home as "the unit of society...the good home is the greatest blessing to mankind, and the bad home is the worst menace" in "A Religious Community of Social Workers," Catholic Charities Review, 124; Margaret McGuinness also writes that both Catholic and non-Catholic settlement workers were focused on "instructing women in the proper care of a home and children," in Margaret M. McGuinness, "Body and Soul: Catholic Social Settlements and Immigration," US Catholic Historian 13, no. 3 (Summer 1995): 67.

${ }^{45}$ Breckinridge, New Homes, 14-17, 84.

${ }^{46}$ Christ-Child Society of Chicago 1915-1916, Madonna Center Records, series 1, box 2, folder 7, Mary Agnes Amberg Papers.

${ }^{47}$ Amberg, Madonna Center, 132; Margaret A. Galvin, "The Growth and Development of Madonna Center, a Catholic Social Settlement" (master's thesis, Loyola University, 1951), 31; Skok, More than Neighbors, 123.
} 
visits conducted in a single month. ${ }^{48}$ Some elements of friendly visiting among Chicago Catholics also had a specifically religious function. Young men associated with the Madonna Center would visit boys in their homes to escort them to confession and ensure they stayed away from negative influences. ${ }^{49}$ Chicago churches also had specific "parish visitors" to "instruct those who are ignorant of the truths of Faith, or who through years of neglect, have forgotten Church and Sacraments." 50

In 1896 the Hull-House Woman's Club developed a Study Class for Friendly Visitors, appointing five members of the club to undertake the role. Besides volunteers, the roster of residents also listed a Miss Esther Gilbertson as a Visiting Teacher and Miss Anita Jones as the specific "Mexican Visitor" for the Immigrants Protective League. ${ }^{51}$ The League, which operated out of Hull-House, would also send a volunteer to visit newly-arrived immigrant families in their homes. ${ }^{52}$

Home visiting had the peculiar effect of both reinforcing and hiding the power dynamic between settlement workers and poor immigrant women. The practice presumed the openness of these women's homes to the public, blurring the lines of public and private that characterized nineteenth century domestic rhetoric. This access positioned

\footnotetext{
${ }^{48}$ Margaret Barry, "The Margaret Barry House," Catholic Charities Review 1, no. 3 (March 1917), 81; "Social Settlements," Catholic Charities Review 1, no. 3 (March 1917), 87.

${ }^{49}$ Skok, More than Neighbors, 95.

50 “A Religious Community," Catholic Charities Review, 124.

${ }^{51}$ List of Residents, box 32, folder 294, Hull-House Collection; Hull-House Bulletin February 1896, box 43, folder 425, Hull-House Collection.

52 Immigrants' Protective League 1935-36, box 56, folder 6, Grace and Edith Abbott Papers, Special Collections Research Center, University of Chicago Library.
} 
settlement workers as having the right to poor women's inner lives, daily habits, and relationships with their children. Hull-House investigators even acknowledged that this sort of invasiveness was likely to cause bad blood, but continued their efforts because they believed the results were too important. ${ }^{53}$ Yet settlement workers also seemed to view this practice as something that bolstered their credibility as neighbors. Presumably, gaining access into a mother's home spaces required her acquiescence (although whether that acquiescence was entirely forthcoming was another matter). Earning such entrance conferred legitimacy on people who based their work on their supposedly genuine connections with the poor. ${ }^{54}$ Rather than focusing on the uneven power dynamic, settlement workers likely felt that they were uniquely suited to conducting these visits because they were fellow women who resided on the same streets.

For Hull-House residents, this work implied that they were capable of forging intimate friendships with poor immigrant communities despite their religious and cultural differences-without which, the settlements' claim to be a model of democratic pluralism might have fallen flat. But for Catholic laywomen-who based their work in religion and justified it by their community's need for religious and moral instruction-the ability to build the same relationships and gain influence among Catholic immigrants implied that their counsel was necessary and welcome. It also reinforced the idea of shared religiondespite class or ethnic differences, these women all belonged to the Catholic Church, and

${ }^{53}$ Hull House Maps and Papers, 14.

${ }^{54}$ See Skok, More than Neighbors, 7-13; Davis, Spearheads, 37; Shannon Jackson, Lines of Activity: Performance, Historiography, Hull-House Domesticity (Ann Arbor, MI: The University of Michigan Press, 2000), 42-47. 
often resided in the same parish. If secular settlement workers were more successful in gaining access to Catholic immigrants' inner lives, it undermined the foundation of shared religion on which Catholic laywomen like Mary Amberg built their work.

For their part, immigrant women found small ways of resisting these incursions into their homes. Margaret Tucker, another prominent figure in Catholic women's charity work, reported that home visiting efforts by Catholic social workers "frequently brought the visitor into contact with elders insultingly hostile to the religious as a class." ${ }^{55}$ She complained that the work was a "thankless task," the visitors' attempts at personal service met with hostility or indifference. Settlement workers on both sides complained of apathy and stubbornness from the mothers they visited. According to Mary Amberg, the women “tenaciously" refused to adopt settlement workers' suggestions on cooking and housekeeping. ${ }^{56}$ Women who tried to give housekeeping advice to Chicago's immigrant mothers described them as "stubborn, indifferent, inert, obstinate, lazy, difficult... and not performing what they undertake." 57 Sophonisba Breckinridge remarked that Italian, Polish, and Lithuanian women "seem to know their own tastes and will do their own way mostly." ${ }^{, 58}$ Rather than apathy, immigrant women's dismissal of settlement workers' instructions and advice was a way for them to stake out the home space as their own sphere of influence. They might not have been positioned to refuse social workers access

55 Margaret Tucker, "Catholic Settlement Work - An Analysis," Catholic Charities Review 2, no. 10 (December 1918), 305.

${ }^{56}$ Amberg, Madonna Center, 132-133.

${ }^{57}$ Breckinridge, New Homes, 288.

${ }^{58}$ Ibid 
to their homes, but they could demonstrate their determination to maintain their own cultural standards and traditions, no matter what the experts had to say.

Years later, settlement workers acknowledged that the knowledge of local mothers may not have been as lacking as they thought. At Hull-House's fortieth anniversary celebration, some of the former residents reflected that they had made mistakes. According to Hilda Satt Polachek,

One of the speakers recalled how she had put in a great deal of time and effort to teach the immigrant women what to feed their babies. They were told not to give babies most vegetables, bananas, and many foods that were found necessary for the growth of children. 'So after forty years,' she said, 'I have come to the conclusion that the immigrant mothers knew much more about feeding children than we specialists did. ${ }^{59}$

\section{The Education Debate}

Public debates around education at the turn of the century also divided these groups of women, ostensibly over the right to raise children according to certain values. In Chicago, settlement workers, Catholics, and immigrant parents all sought to defend their stake in this issue. Hull-House residents advocated for compulsory education until age sixteen and greater standardization of the public schools through increased government intervention. Catholic women and leaders defended their right to an education system founded on faith. They did not want their children influenced by prejudice in the majority-Protestant public schools. And immigrant parents valued the parochial schools because they helped pass on their language, history, and culture to their children. Though children were at the rhetorical center of these debates, education reform

${ }^{59}$ Polachek, I Came a Stranger, 169. 
had far-reaching implications for the role of women, the role of government, and the rights of parents to make decisions about their children's lives.

In pushing for legislation, Hull-House women were positioning themselves as defenders of children and childhood, and as experts on the conditions in their city that needed to be amended to meet this purpose. They were also middlemen who would help filter immigrant children into a system that would mold them into good citizens and offer them greater opportunities. But their efforts to reform education threatened to weaken and undermine the city's Catholic schools, and overrode the wishes of many parents. The Catholic community pushed back against these efforts, defending both the rights of parents and the Church to make educational choices for their children, and to raise them with religious as well as civic values.

Public education was one of the first areas in which reform-minded women in Chicago tried to gain a professional foothold-primarily through working to get women elected to education boards. ${ }^{60}$ Hull-House women in particular emphasized the importance of education as a unifying and equalizing force, and as a vital training ground for future members of a democratic society. ${ }^{61}$ Their major concerns revolved around

${ }^{60}$ Maureen A. Flanagan, Seeing with their Hearts: Chicago Women and the Vision of the Good City, 1871-1933 (Princeton, NJ: Princeton University Press, 2002), 33.

${ }^{61}$ The Immigrants' Protective League, which operated out of Hull-House, encouraged newly-arrived families to immediately enroll their children in the public schools as part of their "Adjustment and Assimilation" initiatives, referenced in Immigrants' Protective League, box 56, folder 6, Grace and Edith Abbott Papers; See also Carson, Settlement Folk, 119; Lissak, Pluralism and Progressives, 44-45; Mary Jo Deegan, Race, HullHouse, and the University of Chicago: A New Conscience Against Ancient Evils (Westport, CT: Praeger, 2002), 7. 
children learning English and a common sense of American identity-which would be accomplished through standardizing the schools in order to ensure a quality education. ${ }^{62}$ Their legal fights to make education compulsory also came from the assertion that children had a right to spend their childhood learning rather than in a factory. ${ }^{63}$

Settlement women's approach to public education emphasized the areas that were lacking. The schools were not held to uniform standards, teachers needed greater education and training, and the public schools didn't have enough space to accommodate all the children in the Nineteenth Ward. ${ }^{64}$ Without adequate facilities and laws requiring students to remain in school, it was harder to keep children out of the factories. They focused on areas in which municipal government was not living up to children's needs, and needed to step in-guided by the advice and suggestions of these reformers.

Hull-House reformers' emphasis on the inadequacies of Chicago public schools ignored the significant presence of the city's parish school system, which expanded greatly during the last quarter of the nineteenth century. After the 1875 Third Plenary Council of Baltimore, which had instructed parents that it was their duty to send their

${ }^{62}$ Lissak, Pluralism and Progressives, 48-52; Addams wrote that the main role of educators was "their manifest obligation to prepare and nourish the child and the citizen for social relation" in Addams, "Educational Methods," January 15, 1904, Jane Addams Papers, https://digital.janeaddams.ramapo.edu/items/show/3586.

${ }^{63}$ For Hull-House residents' opinions on education as solution to child labor issues, see Hull House Maps and Papers, 75.

${ }^{64}$ Florence Kelley criticized the public schools for overcrowded classrooms and incompetent teachers, see Florence Kelley to Jane Addams, August 19, 1904, Jane Addams Papers, https://digital.janeaddams.ramapo.edu/items/show/419; Hull-House also referenced an 1896 survey that found that there were 3,000 more children in the Nineteenth Ward than spots available in the public schools, in Hull-House Bulletin January 1896 , box 43 , folder 425 , Hull-House Collection. 
children to Catholic schools, building and sustaining the parochial school system became one of the Church's top priorities. ${ }^{65}$ The Council cautioned parents against public school teachers who would try to lead their children away from the Church. Additionally, they claimed secular institutions could not nurture the essential, spiritual side of children's nature. The Council declared that if children were not raised with Christian instruction at school, then there was ultimately "no leading a Christian life."66

Mass immigration and the proliferation of national parishes facilitated the widespread growth of parish schools in the city. Between 1880 and 1890, Chicago Catholics established thirty-three new parochial schools, increasing enrollment from 16,000 to over 31,000 children-about a quarter the size of the city's public-school system. ${ }^{67}$ And until 1930, upwards of fifty percent of these students were attending specifically ethnic schools (attached to ethnic parishes). The drive to build up the Catholic school system brought Church leaders and immigrant parishioners together for a common goal-though not entirely for the same reasons. Reverend Wincenty Barzynski argued that Polish children needed a Catholic education, not only because the public schools were too Protestant, but also because they could not nourish the children's sense

65 “Immigration,” Muldoon, 139; Shanabruch, Chicago's Catholics, 1.

66 "Instructions of the Propaganda Fide Concerning Catholic Children in American Public Schools," (1875) in American Catholic History: A Documentary Reader, eds. Mark Massa and Catherine Osborne (New York, NY: New York University Press, 2017); for more on importance of parish schools in the late $19^{\text {th }}$ century, see Phillip Gleason and David Salvaterra, "Ethnicity, Immigration, and American Catholic History," Social Thought 3 (1978): 7; Kathleen Sprows Cummings, New Women of the Old Faith: Gender and American Catholicism in the Progressive Era (Chapel Hill, NC: University of North Carolina Press, 2009), 108.

${ }^{67}$ Shanabruch, Chicago's Catholics, 58; Skerrett, Kantowicz, and Avella, Catholicism, Chicago Style, 50. 
of Polish identity. ${ }^{68}$ Foreign-born parents tended to value the parish schools because they helped bridge the growing gap between themselves and their children. Sophonisba Breckinridge observed that parents sent children to the parochial schools because they wanted a child "to learn the language of his parents, the history and traditions of his country from which he came, and to retain a respect for the experiences and associations that remain of great importance to his parents." 69

Hull-House residents, at least to some degree, took note of this preference among immigrant parents, borne of the anxieties they experienced, watching the younger generation learning English and assimilating quickly to mainstream American culture. Many of Chicago's settlement workers recognized that this generational gap created tension within immigrant families, and wanted to help shore up children's respect for their parents. ${ }^{70}$ Jane Addams lamented the fact that so much stress was placed on learning English in the public schools that immigrant children "become ashamed of their parents because they can't speak English."71

Yet in this area, Hull-House reformers strategically retreated from supporting the desires of immigrant parents. They proposed certain changes to the public schools to

${ }^{68}$ Shanabruch, Chicago's Catholics, 95.

${ }^{69}$ Breckinridge, New Homes, 160.

${ }^{70}$ Sophonisba Breckenridge noted the stress of parents whose children learned English before them (Breckinridge, New Homes, 153-154); Jane Addams repeatedly touted this as one of the major benefits of the Labor Museum, that it allowed children to witness their parent's Old World culture as valuable contributions and heightened their respect for their parents (see First Report of the Labor Museum, box 43, folder 433, Hull-House Collection; Addams, Twenty Years, 235-241).

${ }^{71}$ Addams, Speech to the American League of Civic Improvement, September 24, 1902, Jane Addams Papers, https://digital.janeaddams.ramapo.edu/items/show/16868. 
make them more welcoming or appealing to immigrant parents. Attempting to inject greater tolerance into the school system, Addams advocated for public-school teachers to be better educated in the cultural backgrounds of their students. ${ }^{72}$ Hull-House residents also helped institute ethnic studies as part of Chicago's high-school curriculum. ${ }^{73}$ But these changes were designed to make parents comfortable sending their children to public schools. Social workers who claimed to desire cooperation with the Catholic Church still expressed frustration over parents' insistence on children remaining in parochial schools. Visiting social workers tried to convince parents to withdraw their children and place them in the public schools instead, sometimes even offering stipends or scholarships to mothers. $^{74}$

The state's ability to compel children to remain in school until at least fourteen or sixteen was a major sticking point. While Hull-House residents sympathized with the financial hardships of many of the families in their neighborhood, they despised child labor, and the parents who were complicit in sending their underage children to work instead of school. ${ }^{75}$ Addams felt that social workers ultimately understood children's needs better than their parents. "Many of our Italian neighbors, newly-arrived immigrants, see no use in a child's being taught to read and write," she told the National Conference of Charities and Corrections in 1903. "The only test which is valid with them is the earning capacity of the child. If he can go to work without knowing reading and

\footnotetext{
72 Addams, Remarks on Immigrant Children, March 1906, Jane Addams Papers, https://digital.janeaddams.ramapo.edu/items/show/4230.

${ }^{73}$ Lissak, Pluralism and Progressives, 40.

${ }^{74}$ Breckinridge, New Homes, 297-298.

${ }^{75}$ Carson, Settlement Folk, 119.
} 
writing, it will be done."76 She also wrote that child labor laws had been championed by people who "knew the immigrant, how prone he was to exploit his child, how loth [sic] he was to keep him in school the proper amount of time." 77 The message was clear - this was an area in which the settlement worker, not mother, knew best.

If the issue had been solely focused on keeping children in school through the eighth grade, education could have been an area in which Hull-House reformers and Catholic advocates found common ground. Pope Leo XIII had also condemned child labor in his 1891 encyclical Rerum Novarum, insisting that children be kept in school until "their bodies and minds are sufficiently mature."78 Priests also insisted that a Catholic education made children into better citizens because it laid a moral foundation for personal responsibility. ${ }^{79}$ But Hull-House women had positioned themselves as experts on child welfare, in a claim that elevated them to greater positions of influence in the public realm. (Julia Lathrop and Grace Abbott, two women closely associated with Hull-House, would later be appointed as founding executives of the U.S. Children's Bureau). To acknowledge that a growing number of children in the city attended parochial schools would be to undermine this claim. It would shed light on an expanding system that was filling in the city's educational gaps without pushing for greater

\footnotetext{
${ }^{76}$ Addams, Summary of Discussion on Child Labor at the National Conference of Charities and Corrections, May 11, 1903, Jane Addams Papers, https://digital.janeaddams.ramapo.edu/items/show/1186.

77 Addams, "The Immigrants and American Charities," October 24, 1905, Jane Addams Papers, https://digital.janeaddams.ramapo.edu/items/show/3813.

${ }^{78}$ Leo XIII, Rerum Novarum (Maryknoll, NY: Orbis, 2010), 31.

${ }^{79}$ Shanabruch, Chicago's Catholics, 57.
} 
government involvement-the men and women who administered and taught in these schools desired less government oversight, not more.

Hull-House residents chose to push adamantly for standardization and compulsory education in ways that harmed Chicago's Catholic school system. For one, standardization efforts that required higher levels of education for teachers left parochial schools behind, because nuns who worked as teachers usually didn't meet the new qualifications. ${ }^{80}$ But more importantly, Illinois lawmakers specifically framed these laws in ways that excluded Catholic schools by focusing on the language issue. In 1889 Illinois briefly passed the Edwards Law, which would require students to attend public schools unless they attended a private school approved by the board of educationapproval which required the school to teach in English. However, the law was repealed a year later due to significant backlash from the Catholic school system. ${ }^{81}$

Where the education debate struck at the rights of parents to make decisions about their children, and the Church to rear children according to their traditions and values, it was nothing compared to the controversy over birth control that developed in later years. While the issue of schooling ignited a struggle over children's wellbeing as public versus private domain, settlement workers still agreed on the basic importance of education. But contraception struck at the intimate and explicitly gendered issues of reproduction and

${ }^{80}$ Lissak, Pluralism and Progressives, 51-52; Susan Hill Lindley, "You Have Stept Out of Your Place:" A History of Women and Religion in America (Louisville, KY: Westminster John Knox Press, 1996), 222.

${ }^{81}$ For more on education controversies and the Catholic schools in Chicago, see Shanabruch, Chicago's Catholics, 60-73. 
family life. This was also an area in which religious values created a stricter divide, as these two groups of women found little common ground.

\section{The Birth Control Controversy}

The debate over contraception didn't truly develop between Hull-House and the Church until the second decade of the twentieth century-but when it did, it drove a significant wedge between the two institutions. Here was not simply a debate over sexuality or reproduction, but a struggle over ideals of family, gender roles, and the moral basis of society. For Hull-House women who advocated for birth control, this issue centered around poverty, health, and justice, and they approached it as pragmatists hoping to minimize the suffering of poor families. For Catholic settlement workers and their co-religionists, this issue violated not only the Church's beliefs on marriage and family, but also the concept that personal morality and the Church's dictates should be the measure of social advancement, rather than a secularized version of the greater good. It also meant agents of public organizations intruding on issues of personal morality where they had no right.

The Catholic Church taught that sex within marriage should be focused on procreation, not pleasure, and they condemned birth control as a violation of nature and of God's will, along the same vein as infanticide or self-mutilation. ${ }^{82}$ Until the period

${ }^{82}$ Leslie Woodcock Tentler, Catholics and Contraception: An American History (Ithaca, NY: Cornell University Press, 2004), 16-23; Cardinal Gibbons, "The Needs of Humanity Supplied by the Catholic Religion," in The World's Congress of Religions: The Addresses of Papers Delivered Before the Parliament and an Abstract of the Congresses Held at the Art Institute (Washington, DC: W.B. Gonkey Company, 1893), 813; 
after World War I, contraception remained too taboo a subject to discuss openly from the pulpit. But by the 1920s the Church was prodded into a more public stance by the birth control movement. Certain groups of Catholic immigrant women, including Mexicans, were among those targeted by the eugenicist wing of the movement for their higher birth rates. Margaret Sanger also blamed most of the backlash to her work on the Catholic Church, further prompting the need for a public response. ${ }^{83}$

Hull-House as a settlement did not take a public stance on contraception, and tried to be discreet on discussions around sexuality. They were in favor of sex education, but Addams believed in approaching it from a moralistic perspective, focusing on restraint and discouraging "promiscuity." 84 Besides a motion in 1913 by the National Federation of Settlements to promote sex education in Chicago high schools, the subject remains mostly absent from settlement publications. ${ }^{85}$ But two long-time Hull-house residentsDr. Alice Hamilton and Dr. Rachelle Yarros-were both involved heavily with birth control advocacy. Dr. Hamilton lived at Hull-House intermittently for twenty-two years, from 1897 to 1919; Dr. Yarros lived at the house for twenty years from 1907 to 1927 . In 1917, both women sat on a citizen's committee advocating for the creation of clinics and the right to disseminate information to married women. ${ }^{86}$ Dr. Yarros was also a professor

“"Authorities' Favoring Birth Control," Catholic Charities Review 1, no. 7, (September 1917): 198.

${ }^{83}$ Tentler, Catholics and Contraception, 7, 53; on concerns about Mexican-American birth rates, see Sánchez, "Go After the Women," 292.

${ }^{84}$ Alexandra Fair, "'The Mind has to Catch up on Sex:' Sexual Norms and Sex Education in the Hull House," Paedagogica Historica 54, no. 3 (Jan 2018): 250-251.

${ }^{85}$ National Federation of Settlements 1932, box 55, folder 670, Hull-House Collection.

${ }^{86}$ Diane C. Haslett, "Hull House and the Birth Control Movement: An Untold Story," Affilia Journal of Women and Social Work 12, no. 3 (Sept 1997); "Birth Control Friends 
of obstetrics, sexuality, and contraception, and helped establish the Illinois Birth Control League in the 1920 s. $^{87}$

Their concerns around contraception were guided by a public health perspective. Dr. Hamilton conducted a study of 1600 Chicago immigrant families and found that larger families were correlated with higher infant mortality rates. ${ }^{88}$ She and Dr. Yarros also pointed out that women in the tenements without access to preventative birth control were more likely to resort to dangerous home abortions. ${ }^{89}$ In 1927 , Hull-House opened a birth control clinic attached to the Mary Crane Nursery, "for consultation with parents as to spacing of children and other problems in married life."90 The doctors advised the mothers who used the nursery to stop having children, or to try to space them out more. ${ }^{91}$ Additionally, a social worker who worked at Hull-House in the 1920s recalled "trying to persuade people to go to the birth control clinic and cut down on the number of children they had." 92

Florence Scala, a prominent community activist of the Near West Side, refers to this as the primary reason the Catholic Church had a "quarrel" with Hull-House. ${ }^{93}$ In

Here Sidestep Jail," Chicago Tribune, Feb 16, 1917; "Brundage Gives His Opinion on Birth Control," Chicago Tribune, Feb 25, 1917.

${ }^{87}$ Haslett, "Hull House."

${ }^{88}$ Hull-House Yearbook 1913, box 44, folder 436, 50, Hull-House Collection.

${ }^{89}$ Haslett, "Hull House"; Fair, "The Mind," 250-253.

${ }^{90}$ Hull-House Yearbook 1929, box 44, folder 440, 65, Hull-House Collection.

${ }^{91}$ Florence Scala, box 4, folder 69, Hull-House Oral History Collection, Special Collections and University Archives, University of Illinois at Chicago.

${ }^{92}$ Sally Zimmerman, box 5, folder 88, Hull-House Oral History Collection.

${ }^{93}$ Florence Scala, box 4, folder 69, Hull-House Oral History Collection; Badillo, "Incorporating," 46; Skok, More than Neighbors, 77. 
1934 Dr. Hamilton publicly criticized the Church for continuing to recommend abstinence as the only birth control method for married couples; Church leaders in turn criticized Hamilton for ignoring Catholic teachings on sexuality and marriage. ${ }^{94}$ HullHouse also made the unfortunate choice to name their clinic the "Eugenics Center."95 Though neither Dr. Hamilton nor Dr. Yarros seem to have leaned into the eugenicist wing of the movement, the center's name nevertheless represented a threat to Catholic communities, especially those who were still not accepted as "white" in the postwar years. $^{96}$

Even if Catholics trusted that Hull-House efforts at sex education and birth control were not malicious, they still represented a reframing of marriage, sex, and reproduction to a utilitarian perspective. Mary Amberg wrote that "limiting a family in order to expand its economic status was inherent in all the social objectives of HullHouse," and felt it was the Madonna Center's duty to counter the "birth control propaganda" being spread in the neighborhood. ${ }^{97}$ To use "unnatural" methods of family planning in exchange for greater economic security substituted the divine ideals around family for selfish motives. Catholic opponents of birth control argued that people would minimize the number of children they had so they could focus on themselves and have fewer responsibilities, and that children in these families would turn out more self-

\footnotetext{
94 Haslett, "Hull House."

${ }^{95}$ Hull-House Yearbook 1929, box 44, folder 440, 65, Hull-House Collection.

${ }^{96}$ Donna R. Gabaccia, "Emancipation and Exploitation in Immigrant Women's Lives," in The Oxford Handbook of American Immigration and Ethnicity, ed. Ronald H. Bayor (New York, NY: Oxford University Press, 2016), 114; Brown and McKeown, Poor Belong to Us, 70; Irving, Immigrant Mothers, 3-8.

${ }^{97}$ Amberg, Madonna Center, 134, 192.
} 
centered than their peers who grew up in large families. Contraception also threatened to degrade the very concept of marriage. It reframed the purpose of sex from procreation to pleasure, which was "subversive of the very fundamental basis of family life." 98 Extreme critics of birth control argued that this ultimately degraded women within marriage, and turned sex into "marriage prostitution."99

Since the realm of children and motherhood had so often been the basis of women's activism within the Church, it was only natural that defending the family ideal and working against birth control became a central part of post-WWI Catholic women's activism. The National Council of Catholic Women devoted much of their work to opposing birth control in the 1920 s. ${ }^{100}$ This was not an issue about personal decisions to have children-Catholic settlement workers like Mary Amberg and Marie Plamondon were eschewing marriage and children themselves, along with the religious sisters who had always made such choices. It rather centered on how the Church defined the home as women's throne and marriage as the source of her power and dignity. ${ }^{101}$ Secular social workers were violating these supposedly sacred commands, not for a chaste life of religious service, but in favor of a modern lifestyle with fewer children. These choices indicated a world of shifting gender roles that increasingly de-emphasized the traditional

98 "Undermining the Home," Catholic Charities Review 6, no. 1 (Jan 1922): 26; John A. Ryan, "The Attitude of the Church Towards Birth Control," Catholic Charities Review 4, no. 10 (Dec 1920), 300.

${ }^{99}$ Gibbons, "The Needs of Humanity," 812; Tentler, Catholics and Contraception, 22. ${ }^{100}$ Brown and Mckeown, Poor Belong to Us, 7.

${ }^{101}$ Mary Jane Burns, "Twenty-Five Years of the Catholic Women's League of Chicago," Catholic Charities Review 2, no. 10 (Dec 1918): 309-310; Gibbons, "The Needs of Humanity," 812. 
role of wife, mother, and homemaker. It perverted not only church mandates but also the distinct spheres and roles that women used to assert themselves in a religious community.

On the other hand, advocates of sex education and birth control viewed this as poor families being victimized and condemned to poverty, or health problems or even death, for the sake of dogma. Both groups defended what they believed to be in the best interest of poor women and families in their communities. At the same time, they also projected a kind of ownership over poor women's private lives and bodies. From the Catholic perspective, these were rightfully the concern of the Church and its agents. From the secular perspective, these were becoming the rightful concern of expanding relief and government agencies.

Chicago's poor and foreign-born women certainly fell all along the spectrum when it came to the contraception issue. Diane Haslett writes that immigrant women often ignored advice from doctors like Dr. Yarros and continued to rely on methods passed down from their culture. ${ }^{102}$ And the fact that social workers recalled going to people's homes and trying to "convince" them to visit the birth control clinic indicates at least some resistance on the part of mothers. Yet Dr. Yarros also recorded that many immigrant women were seeking out information on birth control but, in her view, struggling to get access to accurate information. ${ }^{103}$ Social workers in this period also noted Mexican-American women beginning to ask questions about birth control. ${ }^{104}$

\footnotetext{
102 Haslett, "Hull House."

${ }^{103}$ Fair, "The Mind," 260.

${ }^{104}$ Sánchez, "Go After the Women," 292.
} 
It also depended on the women's socioeconomic position. Dr. Yarros was driven in her work by the desperation she witnessed from some of her patients. With regret, she recorded one case in which a young, unmarried woman had come to her and requested an abortion, which Dr. Yarros refused. A few hours later, the woman's body was found in Lake Michigan, apparently having drowned herself, with Dr. Yarros's card still in her pocket. $^{105}$

These contested areas centered on personal and private aspects of women's livesthe way they ran their homes, their children's education, and choices about their bodies and reproductive roles. Yet the debates reflected an early iteration of that later feminist maxim, "the personal is political." Hull-House reformers pushed consistently for expanded government oversight to advance progressive policies on education and birth control, because it was their expertise that would guide these policies. As professional, educated women, their time spent interacting with their neighbors and gathering information (via studies and surveys) assured them that they were best positioned to guide decisions for the welfare of the community. Meanwhile, Catholic women saw the threat these policies posed to the autonomy of their faith community and the teachings of the Church. They pushed back against this movement to place decisions about immigrants' home lives in the hands of secular social workers and government agencies.

Immigrant Perspectives on Hull-House and the Church

${ }^{105}$ Fair, "The Mind," 261. 
An underexamined element of this whole dynamic is the position of Chicago's immigrant communities in these contested spaces. Historians that have noted the tensions between secular settlement houses and Catholic institutions have failed to ask whether immigrant communities aligned more with one side or the other-or whether this distinction meant anything to them at all. Furthermore, too many historical analyses have positioned Chicago immigrants as passive recipients of settlement house policies rather than participants with agency, who chose to relate to each of these institutions according to their community's priorities and needs.

Observations in the secondary literature indicate that the relationship between a group's construction of nationalism and religion was a major factor in how that community chose to relate to the settlement houses. ${ }^{106}$ The Italian and Mexican communities feature far more prominently in Hull-House records than the Irish and Polish communities. This is likely because the Irish were so well represented in the Catholic Church and its institutions, while the Polish immigrants in Chicago had built up a massive parish system that essentially met all of the community's needs. On the other hand, Chicago's Mexican and Italian immigrant communities were split by a nationalism that worked explicitly against the Church, driving at least a portion of the population away from its doors. Additionally, Catholic leaders struggled to produce enough priests

\footnotetext{
${ }^{106}$ Lissak, Pluralism and Progressives, 96-106; Davis, Spearheads, 89; Peggy Glowacki, "Bringing Art to Life: The Practices of Art at Hull House," in Pots of Promise: Mexicans and Pottery at Hull House, 1920-1940, eds. Cheryl R. Ganz and Margaret Strobel (Chicago, IL: University of Illinois Press, 2004), 20-22; David A. Badillo, "Incorporating Reform and Religion: Mexican Immigrants, Hull House, and the Church," in Pots of Promise: Mexicans and Pottery at Hull House, 1920-1940 (Chicago, IL: University of Illinois Press, 2004), 44-50.
} 
that spoke either Italian or Spanish to adequately lead these communities, furthering the potential for immigrants to feel distanced from the Church. And finally, both Italian and Mexican immigrants practiced a folk-style Catholicism that placed far less emphasis on attending church.

For these reasons, Italian and Mexican immigrants appear to have been drawn more to settlement activities than their Irish and Polish counterparts. Yet when one looks at statements by Chicago immigrants themselves, it's also clear that few people were concerned with the factors that divided Hull-House from Catholic settlements and institutions.

Some families in the Near West Side were aware of the division between the Hull-House and the city's Catholic organizations, and noted that their neighbors tended to align with one side or the other. The Provenzale family mentioned that they remembered no religion being associated with Hull-House, and never being "influenced one way or another." But they also recalled that "certain families participated in church activities and other families chose to relate more to Hull-House." ${ }^{107}$ Florence Scala also noted that "Hull-House was not the major influence in this area. The church was the major influence. Hull-House was one of the important influences here...but many people chose not to go there." 108

${ }^{107}$ Donald Provenzale and Family, box 4, folder 61, 8-9, Hull-House Oral History Collection.

${ }^{108}$ Florence Scala, box 4, folder 69, 12, Hull-House Oral History Collection. 
But many other oral histories indicate no sense of division or uncertainty among immigrant families. Teresa Campo, from Calabria, Italy, recalled that "nobody ever said you shouldn't go [to Hull-House]. If they didn't go they didn't go because they either didn't have the time or they didn't speak English or something...Everybody who went to Hull-House they all loved going there." ${ }^{\prime 109}$ Father Geno Del Piaz, a later pastor of Our Lady of Pompeii Church, recalled "only good feelings about Hull-House." 110 And the thirty-one Italian organizations that met at Hull-House covered the spectrum everywhere from labor and nationalist groups to theater to religious study circles. ${ }^{111}$

Evidence also suggests that many members of the Near West Side interacted easily with both Hull-House and the Church. Ralph Mancinelli recalled his mother, who immigrated from Abruzzi, Italy in 1895, was "a very active person in civic affairs...And she was identified with Hull-House as a young woman” while also attending Guardian Angel Church. ${ }^{112}$ Cruz Soto, whose family attended Catholic schools and Guardian Angel Church during the 1930s, said his immigrant mother heard about Hull-House through the school, and was interested in the English classes they offered. ${ }^{113}$ "Rosa", a woman who washed and cleaned clothes at Chicago Commons, was very fond of the settlement house, and after awhile joined the house's Woman's Club. She remembered being glad to learn

\footnotetext{
109 Teresa Campo, box 2, folder 14, 16, Hull-House Oral History Collection.

${ }^{110}$ Father Geno del Piaz, box 2, folder 21, 35, Hull-House Oral History Collection.

${ }^{111}$ Humbert S. Nelli, Italians in Chicago 1880-1930: A Study in Ethnic Mobility (New York, NY: Oxford University Press, 1970), 187.

${ }^{112}$ Ralph Mancinelli, box 4, folder 48, 1, Hull-House Oral History Collection.

${ }^{113}$ Cruz Soto, box 5, folder 77, 1-7, Hull-House Oral History Collection.
} 
English, so she could finally go to confession at the "Irish church." 114 And the Carripesi family, interviewed by Sophonisba Breckinridge, received aid from both settlement houses and the Church during periods of the husband's unemployment. ${ }^{115}$ Finally, Angela DeVito said she was inspired by Jane Addams and "the giving of herself to other people" to go volunteer in the city, including with the Catholic Youth Organization (CYO). ${ }^{116}$ The CYO was established by Chicago’s Bishop Sheill to provide Catholic children with an alternative to the Protestant YMCA/YWCA-but DeVito clearly didn't see religious partisanship as an obstacle to being involved with a variety of organizations.

Immigrant families in Chicago chose to relate to the settlement houses when and how they wanted. They took advantage of the services, classes, and facilities that seemed to serve their community and fit their priorities. There was an obvious demand for Sunday School instruction, considering the surge of children attending Guardian Angel Mission's classes within its first few years. In 1931 the Italian Red Cross also recognized Mary Amberg for her work among the Italian community in Chicago. ${ }^{117}$ Additionally, Lisabeth Cohen writes that Italian parents in Chicago often sent their children to

\footnotetext{
114 "Rosa and the Chicago Commons: 'How Can I Not Love America?"” in Immigrant Women, ed. Maxine Schwartz Seller (New York, NY: State University of New York Press, 1994), 196-199.

${ }^{115}$ Americanization Study Family Interviews, box 1, folder 1, Sophonisba P. Breckinridge Papers, Special Collections Research Center, University of Chicago Library.

${ }^{116}$ Angela DeVito, box 2, folder 23, 3, Hull-House Oral History Collection.

117 Galvin, "Growth and Development," 33.
} 
settlement houses and YMCA activities in defiance of warnings from priests to avoid all such institutions. ${ }^{118}$

After World War I, when Mexican migrants began to move into the Near West Side, they appreciated Hull-House for its English classes and athletic facilities. Many Mexican Chicagoans maintained Spanish as their sole language out of loyalty to their native country, but others were eager to take advantage of Hull-House English classes. ${ }^{119}$ Cruz Soto's mother from Mexico also advised another woman in the neighborhood to go to Hull-House when she was in legal trouble, because they had a group of female lawyers, one of whom spoke Spanish. ${ }^{120}$ Because the city parks, especially on the South Side, tended to be embattled territory between different groups of boys, Mexican boys would also travel to the Near West Side to use Hull-House and other settlements' sports facilities. ${ }^{121}$ Historian Michael Innis-Jiménez writes that settlement houses played an important role in the development of Mexican-American communities in Chicago, and that access to Hull-House services was even a factor in Mexican Americans choosing to live in the Near West Side. ${ }^{122}$

Besides the draw of the house's English courses and recreational offerings, members of the Near West Side also felt that Hull-House facilitated a sense of

${ }^{118}$ Lizabeth Cohen, Making a New Deal: Industrial Workers in Chicago, 1919-1939 (New York, NY: Cambridge University Press, 1990), 91.

${ }^{119}$ Michael Innis-Jiménez, Steel Barrio: The Great Mexican Migration to South Chicago, 1915-1940 (New York, NY: New York University Press, 2013), 87-88.

${ }^{120}$ Cruz Soto, box 5, folder 77, Hull-House Oral History Collection.

${ }^{121}$ Innis-Jiménez, Steel Barrio, 169.

${ }^{122}$ Innis-Jiménez, Steel Barrio, 5, 81; David Badillo also writes that Mexican Americans in Chicago were quite "receptive" to settlement work in Badillo, "Incorporating," 53. 
community. "Even if you were just in the coffee shop having coffee, somebody came in who was not from your neighborhood, stop by to talk and say hello," Florence Scala recalled. "It was the exchange between the people that changed the attitude of many mothers who came to Hull-House." ${ }^{123}$ Hilda Satt Polachek, an immigrant from Poland who befriended Jane Addams and later worked at Hull-House, recalled the same feeling about the Woman's Club, that it "brought together women from all over the world...to sit down and have a cup of tea that you did not have to brew yourself and a piece of cake that you did not have to bake was an event in the lives of the women of South Halsted Street."124 Teresa Campo, an immigrant from Italy, also remembered the House's activities having a huge impact on her life as a young woman. "Even though we married and had children, we continued," she wrote of herself and her friends that socialized at the settlement house. "We never broke away from Hull-House."125

Finally, mothers of the Near West Side seemed to value the settlement houses because they helped regulate the movement of children, funneling them out of the streets and into appropriate spaces. The day nurseries provided an invaluable service to mothers who worked outside their homes. In the early years of Hull-House, Addams observed that mothers would lock children out of the apartments in the summer months because it would get too hot in the tenements. Many of these children ended up at the Hull-House because they had nowhere else to go. ${ }^{126}$ Other parents were unhappy with the relative

${ }^{123}$ Florence Scala, box 4, folder 69, Hull-House Oral History Collection.

${ }^{124}$ Polachek, I Came a Stranger, 100-101.

125 Teresa Campo, box 2, folder 14, Hull-House Oral History Collection.

${ }^{126}$ Addams, Twenty Years, 168-169. 
freedom that youth were afforded in the US, such as the Centracchio family, who expressed their unease with young men and women going out without adult supervision. ${ }^{127}$ Through children's clubs, daycare, and chaperoned dances, the settlement house provided a structured and monitored environment for children and youth. Multiple members of the community recalled Hull-House as valuable precisely because it "kept children off the streets." 128

The Catholic settlements, with their emphasis on Sunday School education and first communion, also played the specific role of filtering children into respectable, proper places within their religious environment. The Madonna Center especially focused on providing clothing for church. Crafting their own first communion dresses was a major project of the sewing classes for girls. In 1905, the Center bought new clothes for the church's twelve altar boys as part of their annual Christmas gift-giving. ${ }^{129}$ When the Great Depression hit, the Center gave almost 4,700 children new clothes for Christmas. ${ }^{130}$ Besides meeting a basic need, providing clothing for children to wear to church allowed the family to feel a greater sense of dignity. The Centracchio family, for example, didn't attend church because they felt they didn't have good enough clothing, and would feel

\footnotetext{
${ }^{127}$ Americanization Study Family Interviews, box 1, folder 1, Sophonisba P. Breckinridge Papers.

${ }^{128}$ Esther A Palella, box 4, folder 57, Hull-House Oral History Collection; Donald Provenzale and Family, box 4, folder 61, Hull-House Oral History Collection. ${ }^{129}$ Amberg, Madonna Center, 67.

${ }^{130}$ Christ-Child Society of Chicago 1915-1916, Madonna Center Records, series 1, box 2, folder 7, Mary Agnes Amberg Papers.
} 
embarrassed in front of the other families. ${ }^{131}$ Having children dressed well for church conferred dignity on the family-especially mothers-in a public way.

However, there was one exception to Chicago immigrants' appreciation for the space the settlement houses provided. Many people perceived Hull-House to be a shining example of democratic pluralism, representing the many nationalities of Chicago. Hilda Satt Polachek recalled being struck by the diversity she experienced at a celebration at Hull-House during one of her first visits. "There were children and parents at this party from Russia, Poland, Italy, Germany, Ireland, England, and many other lands," she wrote, "but no one seemed to care where they had come from, or what religion they professed, or what clothes they wore, or what they thought."132 Others recalled images of children of different nationalities, from different parts of the city, linking hands and dancing together in their classes. ${ }^{133}$ But some residents of the neighborhood were unhappy with such cultural intermixing when it came to their children. Sadie Garland Dreikurs, daughter of a Jewish Lithuanian immigrant family, recalled that her parents didn't want her going to Hull-House or becoming friends with Italian children. "They were sure I would marry an Italian-that would be forbidden," she wrote. For her parents, it was "an awful place, Hull House. So many things happened there that were strange to them." ${ }^{\prime 34}$ In the earlier years, some of the German parents complained that the Italian children were dirty, and wanted

${ }^{131}$ Americanization Study Family Interviews, box 1, folder 1, Sophonisba P. Breckinridge Papers.

132 Polachek, I Came a Stranger, 51-52.

${ }^{133}$ Nesta Smith, box 5, folder 76, Hull-House Oral History Collection.

${ }^{134}$ Sadie Garland Dreikurs, box 2, folder 26, Hull-House Oral History Collection. 
them kept away from the house. ${ }^{135}$ As the neighborhood demographics shifted, Italian families began to express the same sentiments towards their new Mexican neighbors. In the 1920s a group of Italians protested against Hull-House allowing Mexicans to use Bowen Hall, and others wanted the facilities to be off-limit to Mexicans entirely. ${ }^{136}$

This is where Hull-House's commitment to this vision of a pluralistic environment of all nations and religions began to break down. But it fractured along specific lines of ethnicity. In the early years the workers designated specific classes and clubs for Italians, but they did not attempt to actually segregate certain European nationality groups from each other. But when Mexican and African American migrants began to take up residence in the Near West Side, the house began adopting policies of differential inclusion, or creating alternative activities and resources for these groups instead of incorporating them into the already-existing programs. Similarly, Madonna Center continued to focus on serving the Italian community even as Mexicans and African Americans became a larger portion of the nearby population. The way in which settlement houses chose to draw lines of inclusion and exclusion reinforced emerging lines of whiteness, and placed those outside of it on the margins, even as they preached pluralism and diversity.

\footnotetext{
135 Jackson, Lines of Activity, 71.

136 Thomas A. Guglielmo, White on Arrival: Italians, Race, Color, and Power in Chicago, 1890-1945 (New York, NY: Oxford University Press, 2003), 48; Gabriela F. Arredondo, "Navigating Ethno-Racial Currents: Mexicans in Chicago, 1919-1939," Journal of Urban History 30, no. 3 (March 2004): 418; Glowacki, “Bringing," 22.
} 


\section{Chapter 3 - Reinforcing the Color Line}

The exclusion or limited accommodation of African Americans and Latinos at Hull-House is rarely discussed because most historians have confined their research to the period directly before or after World War I, and it is in this period that these two demographics began to take up significant presence in the Near West Side. While Elisabeth Lasch-Quinn's research focuses on the absence of African Americans in typical settlement house work, her work stays within a black-white binary, missing the experience of Mexican immigrants, and the overall implications of the settlement house decisions for the changing nature of whiteness and race relations in the interwar period.

Hull-House residents were not racist in the traditional sense, and in fact participated in much anti-racist work. ${ }^{1}$ But the way they decided who got to be included in mainstream settlement programs versus who needed separate activities or even separate organizations followed the era's solidifying racial lines. They adopted strategies of differential inclusion-neither full segregation nor equal integration. These decisions demonstrate that while they were not racist or strictly inclusive to whites, European groups had always been the central focus of settlement house work. Settlement houses' decisions in this area both followed and reinforced the interwar period's solidification of the color line into categories of white and non-white, and centered whiteness as the norm in the settlement house environment, while marginalizing Latinos and African Americans.

\footnotetext{
${ }^{1}$ See Mary Jo Deegan, Race, Hull-House, and the University of Chicago: A New Conscience Against Ancient Evils (Westport, CT: Praeger, 2002), 4, 39-77.
} 
The Changing Face of Whiteness

Throughout the end of the nineteenth and early twentieth century, race and ethnicity continued to be reconstructed and renegotiated, as successive waves of immigration and migration defied societal attempts at easy categorization. Whiteness continue to be the indisputable measure of privilege and mobility, but its parameters remained ill-defined. For example, while Italians usually counted as white, in 1903 the Democratic party tried to prevent both Italians and Mexicans from voting in "white primaries." Racial scientists of the period often referred to multiple "white races" rather than one. ${ }^{2}$ Mexican immigrants presented an especially confusing case for social scientists. They occupied a fuzzy in-between space on the color line, not "colored" by the antebellum black-white binary, but not European or clearly white either. ${ }^{3}$ A study entitled The Mexican in Chicago, to which Hull-House resident Anita Jones contributed her research, observed that within the Mexican community there were "many gradations of racial strains from the pure Indian type, through the predominating Spanish and Indian mixed blood or mestizo types, to the negligible percentage of pure white stock."4

After World War I, the color line, and the definition of whiteness as a racial category began to solidify. "Race" and "color" started to merge into the same concept,

\footnotetext{
2 Thomas A. Guglielmo, White on Arrival: Italians, Race, Color, and Power in Chicago, 1890-1945 (New York, NY: Oxford University Press), 8-9, 27; Matthew Frye Jacobson, Whiteness of a Different Color: European Immigrants and the Alchemy of Race (Cambridge, MA: Harvard University Press), 6-7, 39-41.

${ }^{3}$ Gabriela F. Arredondo, "Navigating Ethno-Racial Currents: Mexicans in Chicago, 1919-1939," Journal of Urban History 30, no. 3 (March 2004): 402.

${ }^{4}$ Robert C. Jones and Louis R. Wilson, The Mexican in Chicago (Chicago, IL: Chicago Congregational Union, 1931), 16.
} 
distinguishable from ethnicity or nationality, which became less important. Historian Matthew Frye Jacobson identifies the mid-1920s as a turning point in which the public began to focus on "major racial divisions" over minor distinctions of ethnicity. In Chicago this was especially spurred by the 1919 race riots, which further divided the city along lines of white and black. ${ }^{5}$ Additionally, the 1921 immigration quotas slowed the influx of European immigrants in comparison to the increasing migration of African Americans from the South.

In the years following the war, European ethnic groups began to view themselves as having more common ground, as compared to those not from Europe. A sociologist who studied boy gangs in the 1920s noted that "white" gangs of mixed nationalities were becoming more common, and were often created in reaction to black migration to the neighborhood. ${ }^{6}$ Whiteness began to emerge as a stabilizing category at the expense of non-white groups. ${ }^{7}$

Gabriela Arredondo writes that Mexican immigrants in Chicago came into conflict with African-Americans as they tried to separate themselves from black communities and signal their "nonblackness." ${ }^{8}$ Though often successful in these attempts,

\footnotetext{
${ }^{5}$ Guglielmo, White on Arrival, 9, 43; Linda Joyce Brown, The Literature of Immigration and Racial Formation: Becoming White, Becoming Other, Becoming American in the Late Progressive Era (New York, NY: Routledge, 2004), 13.

${ }^{6}$ James R. Barrett and David R. Roediger, "The Irish and the 'Americanization' of the 'New Immigrants' in the Streets and in the Churches of the Urban United States, 19001930," Journal of American Ethnic History 24, no. 4 (2005): 14-15.

${ }^{7}$ Guglielmo, White on Arrival, 56; Jacobson, Whiteness, 9.

8 Arredondo, "Navigating," 405.
} 
Mexicans for the most part were not welcomed into the category of white. ${ }^{9}$ The paths to upward mobility that facilitated European ethnic groups' eventual inclusion as whites did not extend to Mexicans or African Americans. The fact that few Mexican Americans chose to apply for naturalization increased their perceived difference from the nativeborn white population, but some members of the Chicano community in Chicago observed that they were treated as outsiders whether or not they became citizens. It turned some of them sour on the idea of naturalizing, as citizenship didn't protect them from discrimination in the workplace or in the streets. Another portion of the Mexican migrant community had always considered themselves sojourners who would soon return to Mexico, which further separated them from their European counterparts. ${ }^{10}$

Postwar changes within the Chicago archdiocese also helped solidify racial categories in this Catholic community. In 1915 Cardinal George Mundelein became archbishop and, in a reversal from the policies of his predecessors, began a vigorous campaign of Americanization within the Church. Mundelein declared that the era of the national parish was at an end, rejected hyphenated identities, and sought to push immigrant groups towards full assimilation with mainstream American culture. He even ordered all Catholic schools to switch over to instruction in English. However, Mundelein made an exception for Mexican and majority African American parishes. ${ }^{11}$ After the war,

${ }^{9}$ Gabriela F. Arredondo, Mexican Chicago: Race, Identity, and Nation, 1916-39 (Urbana, IL: University of Illinois Press, 2008), 8-9.

${ }^{10}$ Michael Innis-Jiménez, Steel Barrio: The Great Mexican Migration to South Chicago, 1915-1940 (New York, NY: New York University Press, 2013), 97-105.

${ }^{11}$ Edward R. Kantowicz, "Cardinal Mundelein of Chicago and the Shaping of TwentiethCentury American Catholicism," The Journal of American History 68, no. 1 (June 1981): 63; David A. Badillo, "Incorporating Reform and Religion: Mexican Immigrants, Hull 
he announced that St. Monica, which had been a historically black church but maintained a small contingent of white parishioners, would henceforth be reserved "entirely for the colored Catholics of Chicago." 12 This decision came in spite of the fact that many black Catholics opposed having a "national" church for African Americans, perceiving itastutely-as a form of segregation and exclusion. ${ }^{13}$ While Mundelein pushed the city's various European ethnic parishes to unite under a singular Catholic identity, it appeared that he was less confident in the ability to include Mexican and African American Catholics under the same umbrella.

Catholic schools also approached their student bodies with a strategy of segmented inclusion. Archbishop Mundelein's decision to push for dissolving European national parishes while supporting separate churches for Latinos and African Americans facilitated this segregation, as schools were almost always attached to a church. Housing segregation further perpetuated separation in schools. ${ }^{14}$ But certain elements in the Church intentionally participated in racializing the parochial schools. In his 1928 study on Catholic elementary schools, Robert Enlow O'Brien noted that at least one priest appealed to prejudice when trying to convince parents to enroll their children in the

House, and the Church," in Pots of Promise: Mexicans and Pottery at Hull House, 19201940 (Chicago, IL: University of Illinois Press, 2004), 51; Ellen Skerrett, Edward R. Kantowicz, and Steven M. Avella, Catholicism, Chicago Style (Chicago, IL: Loyola University Press, 1993), 25-26.

12 Timothy Neary, "Black-Belt Catholic Space: African-American Parishes in Interwar Chicago," U.S. Catholic Historian 18, no. 4 (Fall 2000): 79.

${ }^{13}$ John T. McGreevy, Parish Boundaries: The Catholic Encounter with Race in the Twentieth Century Urban North (Chicago, IL: University of Chicago Press), 34-35. ${ }^{14}$ Anita Jones observed that in 1928, only $9.8 \%$ of the elementary-age Mexican children in Chicago were enrolled in Catholic schools, in Anita Edgar Jones, "Mexican Colonies in Chicago," Social Services Review 2, no. 4 (Dec 1928): 592. 
parochial system. The priest reportedly said, "I show them that if their children go to the public schools they have to sit by niggers, Jews, and foreigners. While if they come to the Sisters' school they will be seated next to Christians of their own kind." 15 This study came more than a decade after Archbishop Mundelein's initial push to erase "hyphenated" identities among Catholics, demonstrating that segregation and prejudice still operated openly in Church institutions while lines between "white" Catholics were breaking down. ${ }^{16}$

Mundelein's decision to draw the line of unity and assimilation at the Latino and black communities is indicative of a similar trend occurring in the settlement houses. While immigrant groups from Europe made up the core of settlement work, residents in the interwar period felt the need to establish (to varying degrees) separate facilities or opportunities for Mexicans and African Americans.

\section{Hull-House and Anti-Racism}

In their political actions and professed ideology, Hull-House leaders worked against explicitly racist policies. Jane Addams maintained a continuous friendship with both Ida B. Wells (who sometimes spoke at Hull House) and W.E.B. Du Bois. ${ }^{17}$ At the

${ }^{15}$ Robert Enlow O'Brien, "A Study of the Roman Catholic Elementary Schools of Chicago," (PhD diss., Northwestern University, 1928), 47.

${ }^{16}$ For more on segregation in Catholic schools see Dominic A. Pacyga, Chicago: A Biography (Chicago, IL: University of Chicago Press, 2009), 205; Kevin J. Burke and Brian R. Gilbert, "Racing Tradition: Catholic Schooling and the Maintenance of Boundaries," Race Ethnicity and Education 19, no. 3 (2016).

${ }^{17}$ Hull-House Yearbook 1913, box 44, folder 436, Hull-House Collection, Special Collections and University Archives, University of Illinois at Chicago; Deegan, Race, 3965. 
turn of the century Addams and Wells worked together to protest segregation in the public schools. In 1900 the Chicago Tribune planned to run a two-week campaign promoting school segregation; Addams and Wells assembled a group of influential Chicagoans and personally visited the Tribune's office to protest the articles-after which the paper immediately dropped the campaign. ${ }^{18}$ Du Bois also collaborated with some of the Hull-House sociologists on his research on conditions among African Americans in Philadelphia, and in 1905 he invited Addams to give a twenty minute speech to the Tenth Annual Conference to Study the Negro Problem. ${ }^{19}$ Additionally, Jane Addams, Florence Kelley, and Mary McDowell (of the University of Chicago Settlement) all sat on the founding board of the NAACP, which often held meetings at Hull-House. ${ }^{20}$

The closely-associated Immigrants' Protective League also worked to defend the rights of Mexican migrants during the deportation campaigns. IPL members wrote to officials protesting the deportation programs. They also helped advocate for those who had been deported, but were dropped unceremoniously at the border without a way to get back to their hometown in Mexico. The League contacted the Mexican government directly to ask them to help repatriated workers arrive safely at their destination. ${ }^{21}$ Michael Innis-Jiménez also writes that settlement house work with Mexicans in Chicago

\footnotetext{
${ }^{18}$ Deegan, Race, 77; Maureen A. Flanagan, Seeing with their Hearts: Chicago Women and the Vision of the Good City, 1871-1933 (Princeton, NJ: Princeton University Press, 2002), 49.

19 "W.E.B. Du Bois to Jane Addams," April 19, 1905, Jane Addams Papers, https://digital.janeaddams.ramapo.edu/items/show/800; Deegan, Race, 52.

${ }^{20}$ Hull-House Yearbook 1916, box 44, folder 437, Hull-House Collection; Deegan, Race, 65 .

${ }^{21}$ Badillo, "Incorporating," 49; Arredondo, Mexican Chicago, 96.
} 
included "protecting them from obvious forms of discrimination and harassment by property owners, employers, and city leaders." 22

Breaking down barriers in the community was essential to the original HullHouse methodology. One of Addams's early priorities was overcoming differences of race and language, and working against "over-differentiation" in the neighborhood. Children's clubs at the house also taught the idea that American democracy required the breakdown of cultural barriers. ${ }^{23}$ One woman from the neighborhood remembered that on Saturday afternoons, "you would see these little Italian children, the Greek children, the Jewish children linking hands with the children from the Francis Parker School and the Near North Side. And Jane Addams would say, 'They can learn from each other.",24

Yet these commitments were made in the earlier years of the settlement movement when most members of the surrounding neighborhoods were European immigrants. The goal of removing cultural and racial barriers stayed relatively steady when it came to European ethnic groups, but reversed course when it came to Mexican migrants and African Americans. When the demographics of the neighborhood changed, Hull-House began organizing its activities around separation rather than inclusivity. An Alternative Approach: Settlement Houses and Segregated Activities

22 Innis-Jiménez, Steel Barrio, 5; Arredondo, Mexican Chicago, 39.

${ }^{23}$ Jane Addams, Twenty Years at Hull-House with Autobiographical Notes (New York, NY: The MacMillan Company, 1911), 126-127; Rivka Shpak Lissak, Pluralism and Progressives: Hull House and the New Immigrants, 1890-1919 (Chicago, IL: University of Chicago Press, 1989), 44-45.

${ }^{24}$ Nesta Smith, box 5, folder 76, Hull-House Oral History Collection, Special Collections and University Archives, University of Illinois at Chicago. 
The management of tensions between different groups who regularly attended Hull-House was a factor in the residents' decisions to segregate certain activities. Throughout the 1920s, Mexicans on the Near West Side developed a consistent presence at the house. By 1929 Chicano members of the neighborhood were meeting for a program and dance in the dining hall every Thursday evening. ${ }^{25}$ They utilized in the arts and pottery classes, and at least five Mexican clubs met regularly at the house in $1935 .^{26}$ However, both Hull-House and the University of Chicago Settlement separated Mexican boys from others in an attempt to prevent altercations. ${ }^{27}$ At one point Hull-House tried to establish certain hours when specific groups of children were or were not allowed to use the facilities, presumably also to minimize conflict. This approach backfired when it caused some of the Mexican children in the neighborhood to believe they weren't allowed in the house at all. "...the way it had been absorbed in [the children's] hearts and in their minds," one Mexican woman in the community explained, "it was that because they were Mexican they were not permitted in the Hull-House."28

The Madonna Center similarly refused to adjust itself to the growing Mexican community in its backyard. In her memoir, Mary Amberg responded to questions of why Madonna Center didn't serve the Mexican or African American communities. She insisted that it was simply an Italian area, and that the workers "did not choose those

\footnotetext{
${ }^{25}$ Hull House Year Book 1929, box 44, folder 440, Hull-House Collection. ${ }^{26}$ Halsted's Mexican American Community and Hull House, 1934-1937, box 1, folder 11, Adena Miller Rich Papers, Special Collections and University Archives, University of Illinois at Chicago.

${ }^{27}$ Arredondo, Mexican Chicago, 99.

${ }^{28}$ Marie D. Diaz, box 2, folder 25, Hull-House Oral History Collection.
} 
whom we wished to serve." 29 But the fact that they continued to focus single-mindedly on Italians means that they were ignoring the substantial Mexican Catholic population as it slowly became prominent on the Near West Side. In 1917 when they were kicked out of the St. Francis of Assisi school, the women talked about struggling to find another location within the Italian-American colony, even though the Mexican immigrant population was beginning to grow at this point. These women did not consider reorienting their activities to their new Mexican neighbors, even though the presence of Mexican children at other major settlement houses suggests they would have happily embraced the Center's activities. ${ }^{30}$

Some programs and activities for African Americans were segregated as well. In 1927 Hull-House started a Black Mothers Club, but the women weren't invited to any of the main community events. ${ }^{31}$ Juanita Robinson, an African American woman in the Near West Side, remembered getting a grant to take a nursing aide course specifically for black women at Hull-House. ${ }^{32}$ Overall, there was a rather conspicuous absence of African Americans in the house's activities even as they came to be a significant portion of the Near West Side's demographic. The exclusion of African Americans from major activities was a common theme among many settlement houses. Historian Elisabeth

29 Mary Agnes Amberg, Madonna Center: Pioneer Catholic Settlement (Chicago, IL: Loyola University Press, 1976), 30.

30 Amberg, Madonna Center, 100

${ }^{31}$ Elisabeth Lasch-Quinn, Black Neighbors: Race and the Limits of Reform in the American Settlement House Movement, 1890-1945 (Chapel Hill, NC: University of North Carolina Press, 1993), 24; at the time there was also an Italian Mothers Club and a Mexican Mothers Club.

${ }^{32}$ Juanita Robinson, box 4, folder 63, Hull-House Oral History Collection. 
Lasch-Quinn writes that settlements confronted with a growing black population responded in a few different ways, including migrating out of the neighborhood with their historically core immigrant group, conducting segregated activities, or helping to establish separate facilities for their black neighbors. ${ }^{33}$ Hull-House also took the latter approach, collaborating with Dean Walter T. Sumner to establish Wendell Phillips House, for the "large colored population of the West Side." The board held most of its meetings at Hull-House, but remained a separate establishment. ${ }^{34}$ Wendell Phillips was one of three settlement houses in Chicago, along with Emanuel Settlement and the Negro Fellowship League in the Black Belt, that opened to specifically serve African Americans. ${ }^{35}$ Only a few social settlements attempted genuine integration, and those that did sometimes had to contend with a mass exodus of their European immigrant base. Chicago's AbrElisabeth aham Lincoln Center (ironically) faced this issue as many of its white neighbors refused to use the facilities if they were open to African Americans. ${ }^{36}$

Avoiding conflict and attempting to hold onto their historical base of immigrant neighbors, then, was a major impetus for the social settlements' decisions to differentiate inclusion within some of their activities. Additionally, some settlement residents were

\footnotetext{
${ }^{33}$ Lasch-Quinn Black Neighbors, 24, Judith Trolander, Professionalism and Social Change: From the Settlement House Movement to Neighborhood Centers 1886 to the Present (New York, NY: Columbia University Press, 1987), 22.

${ }^{34}$ Hull-House Yearbook 1916, box 44, folder 437, Hull-House Collection.

${ }^{35}$ Robert A. Woods and Albert J. Kennedy, Handbook of Settlements (New York, NY: The Russell Sage Foundation, 1911), 38-47; Patricia A. Schechter, Ida B. Wells-Barnett and American Reform, 1880-1930 (Chapel Hill, NC: The University of North Carolina Press, 2001), 169-213.

${ }^{36}$ Lasch-Quinn, Black Neighbors 27; see also Allen F. Davis, Spearheads for Reform: The Social Settlements and the Progressive Movement 1890-1914 (New York, NY: Oxford University Press, 1967), 95.
} 
likely concerned about the potential for controversy that a mixed-race environment posed in the 1920s and 1930s. Because so many Hull-House residents were white women, integration would bring them into regular contact with black men, which was bound to offend the sensibilities of some of the house's wealthy donors. For example, Louise de Koven Bowen, one of Hull-House's major sponsors, believed in equality for African Americans but didn't necessarily support integration. ${ }^{37}$

Another possible reason behind these decisions was that many reformers believed African Americans were better off creating their own institutions. This was a more covert expression of segregationist impulses, as it allowed reformers to rhetorically support the black community from a distance without having to commit to integration in their own work. Some of the basis for this view also came from explicitly racist sentiments. LaschQuinn writes that some settlement workers believed African Americans had been stripped of all culture and family structure under slavery, and had to now be educated in the basics of civilization. ${ }^{38}$ This was a sharp reversal from the enamored focus on the background and historical contributions of European immigrant groups like Greeks and Italians.

This leaves the question of how to read these decisions within the context of HullHouse and its purported values of equality across racial and religious divisions. I don't believe this should be read as overt racism simply hiding behind the guise of progressivism. Addams and other Hull-House women put too much of their time towards anti-racist work, and gained too much respect from reformers like Wells, for that to be

\footnotetext{
${ }^{37}$ Lasch-Quinn, Black Neighbors, 15-16.

${ }^{38}$ Ibid 6-11.
} 
true. Lasch-Quinn also writes that, for the settlement houses' failures, their approach to African American communities still surpassed that of many other organizations of the era. ${ }^{39}$ But their decisions were not a cut-and-dry capitulation to the desires of their donors and/or white immigrant constituency, because various European nationalist groups had harbored similar prejudices against each other in the earlier years of the house. Prejudice against Italians (combined with their dominant presence in the neighborhood) had prompted Hull-House to set aside several clubs and classes specifically for the Italian community. ${ }^{40}$ However there is no evidence to suggest that these provisions meant Italians were barred from any of the house's mainstream events or activities. They were not confined to separate hours, and especially not shuffled into separate settlement houses.

Hull-House residents compromised on their professed values of democratic pluralism and equality to minimize tensions in the houses. But the places in which they chose to compromise indicate that they were still influenced by the racial trends of the day that centered on a newly normalized whiteness. At the end of the day, they believed European immigrants could overcome cultural and linguistic differences to come together under one democratic umbrella; but they saw this goal as unlikely, or even unattainable when it came to their Mexican and African American neighbors. Madonna Center similarly closed ranks around its original Italian neighbors, reflecting patterns in the

\footnotetext{
${ }^{39}$ Ibid 33.

${ }^{40}$ Shannon Jackson, Lines of Activity: Performance, Historiography, Hull-House Domesticity (Ann Arbor, MI: The University of Michigan Press, 2000), 71; Guglielmo, White on Arrival, 47.
} 
Catholic Church as they emphasized unity among European immigrants, and separation among their other parishioners. Settlement house leaders' perception of who remained within the mainstream of the house's activities, and who must be accommodated from a place on the margins, reflected these emerging postwar lines of whiteness. In adapting to them, settlement residents helped reinforce such boundaries in their own community. 


\section{$\underline{\text { Conclusion }}$}

The settlement houses represent a bridge in urban history between an era of stronger private organizations with an explicitly gendered and religious framework of female benevolence, to a period of an expanding public sphere and strengthened government influence, with less gendered patterns of participation. Churches and clubs as the primary facilitators of women's involvement in social welfare gave way to government bureaucracies and social work programs. Chicago also started this period with a rapidly fluctuating population defined by varying cultural, ethnic, and linguistic backgrounds. By the 1930s, constructions of race and ethnicity had settled into a distinctly racial caste system that centered European heritage as the defining element of inclusion and privilege.

The influence of the social settlements decreased in the wake of the Great Depression. ${ }^{1}$ Many of the expanded public programs for which settlement workers pushed ended up replacing their roles in the neighborhood. Hull-House and some of the larger settlements adapted to this by collaborating closely with federal agencies, and in the 1930s many of the workers living as residents at Hull-House were on the WPA payroll. ${ }^{2}$ But even if the settlements themselves lost overall influence to the New Deal, the movement succeeded in opening up new opportunities and spaces for women's public

\footnotetext{
${ }^{1}$ See Judith Trolander, Settlement Houses and the Great Depression (Detroit, MI: Wayne State University Press, 1975), 29-31, 61-63; Mina Carson, Settlement Folk: Social Thought and the American Settlement Movement, 1885-1930 (Chicago, IL: The University of Chicago Press, 1990), 182-196.

2 Trolander, Settlement Houses, 46-47.
} 
involvement. The close relationship that Hull-House built with the University of Chicago, and the research they conducted throughout the city, helped facilitate the development of social work as a profession. Several women associated with Hull-House also moved up into positions of federal influence. Jane Addams was influential in developing the platforms of the Progressive Party and prior to World War I, publicly supported Teddy Roosevelt's campaigns. Julia Lathrop and Grace Abbott also became the first two executives of the U.S. Children's Bureau. And Sophonisba Breckinridge and Edith Abbott helped design New Deal policies, including the 1935 Social Security Act. Not all Hull-House residents followed a trajectory towards greater political activity. For her part, Ellen Gates Starr withdrew from settlement activities in her later years, and in 1920 she formally converted to Catholicism and retired to a convent in Suffern, New York. ${ }^{3}$

Expansion of government programs was not the outcome Chicago Catholics had historically hoped for. But the process opened doors for Catholic laywomen, even as they insisted that professionalization and recognition were not their goals. The push to be experts who could influence policy decisions regarding poor Catholics prompted the opening of more Catholic colleges for women, with programs in social work. ${ }^{4}$ Working

\footnotetext{
${ }^{3}$ See Suellen Hoy, Ellen Gates Starr: Her Later Years (Chicago, IL: Chicago History Museum, 2010); Thomas Davis, "New Directions in Catholic Historical Research: Saints in Social Work," Journal of Religious and Theological Information 16, no. 4 (2017): 141151.

${ }^{4}$ Aaron I. Abell, American Catholicism and Social Action: A Search for Social Justice 1865-1950 (Garden City, NY: Hanover House, 1960), 182-183; Kathleen Sprows Cummings, New Women of the Old Faith: Gender and American Catholicism in the Progressive Era (Chapel Hill, NC: University of North Carolina Press, 2009), 99; Deborah A. Skok, More than Neighbors: Catholic Settlements and Day Nurseries in Chicago 1893-1930 (Dekalb, IL: Northern Illinois University Press, 2007), 127.
} 
to develop a space for professional women within the context of the Church continued to be a challenge, especially when the subject of salaries was brought in. But the expansion of professionalized social workers within Catholic circles ultimately benefitted the Church because it helped Catholic organizations position themselves for federal funding. ${ }^{5}$ Catholic women also gained the opportunity to represent their communities and values in expanding government spaces, such as the Conference for the Care of Dependent Children. ${ }^{6}$ Issues of motherhood and child welfare continued to be defining platforms for female reformers, but at a much higher level with more widespread influence.

The Great Migration, the industrial demands of World War I, and the 1921 and 1924 immigration quota laws all contributed to Chicago’s shifting racial and ethnic landscape in the early twentieth century. In this arena of destabilized categories, immigrants used the churches and social settlements to gather as a community and, in some cases, stake out their space in the neighborhoods. Immigrants could use these institutions for effective community-building, but also to draw dividing lines between themselves and other groups. The decisions made by settlement workers and Catholic schools and Church leaders to mitigate tensions between immigrant communities placed a stronger dividing line between white and non-white groups. These choices had

\footnotetext{
${ }^{5}$ Dorothy M. Brown and Elizabeth McKeown, Poor Belong to Us: Catholic Charities and American Welfare (Cambridge, MA: Harvard University Press, 1997), 7-8, 64-67; Archbishop Mundelein was able to get the Central Charities Bureau and the Society of St. Vincent de Paul established as distributors of FERA funds (Lizabeth Cohen, Making a New Deal: Industrial Workers in Chicago, 1919-1939 (New York, NY: Cambridge University Press, 1990), 269).

${ }^{6}$ Laywomen were also involved in the drafting of Aid to Dependent Children Laws, Brown and McKeown, Poor Belong to Us, 5-8.
} 
implications for both social conceptions of race, and physical access to neighborhoods, public spaces, and services. Segregation was most explicit regarding African Americans, as evidenced by the fact that settlement workers produced separate settlement houses for their black neighbors but not for Latinos. But those whose place on the color line remained more ambiguous still ended up excluded from the bounds of whiteness in ways that tended to restrict their access to resources. The decisions made by reformers in this period were simultaneously indicators and reinforcers of a solidifying color line.

The interactions of the Catholic organizations and Hull-House, and of the immigrant groups they hoped to serve, demonstrate the importance of this intersectional approach that evaluates race and ethnicity in conjunction with religion, gender, and nationality. Focusing on one element can obscure the way other elements had the power to either divide or transcend boundaries. Hull-House was an institution dedicated to nondenominationalism and the reduction of barriers-yet at times it bowed to racial politics of the period and adopted policies of differential inclusion. Catholic leaders and settlement workers, in the same manner, announced their dedication to serving the entire Catholic body, but the demographic realities of their schools, churches, and settlement houses did not match the message. The secular mission statement of Hull-House also had the capacity to divide rather than unite, as it underestimated the importance of sacred spaces to many Catholic immigrants, and attracted divisive members such as Alessandro MastroValerio and El Frente Popular. And the particular ways in which Hull-House women clashed with Catholic charity and settlement workers demonstrate that women's priorities did not always align with those of men in political or religious leadership positions. 
These shifting, multilayered struggles for influence-taking place in social settlements, in schools, in neighborhood boundaries, in churches-created new patterns of inclusion and exclusion. Each group's attempts to stake out their space in the city altered the political and social landscape of Chicago in enduring ways. 
Bibliography

\section{Primary Sources}

$\underline{\text { Archival Collections }}$

Abbott, Grace and Edith, Papers. Special Collections Research Center, University of Chicago Library.

Addams, Jane, Papers. Digital Edition. Ramapo College of New Jersey. https://digital.janeaddams.ramapo.edu.

Breckinridge, Sophonisba P., Papers. Special Collections Research Center, University of Chicago Library.

Hull-House Collection. Special Collections and University Archives, University of Illinois at Chicago.

Hull-House Oral History Collection. Special Collections and University Archives, University of Illinois at Chicago.

Madonna Center Records. Amberg, Mary Agnes, Papers. Special Collections and University Archives, Marquette University.

Rich, Adena Miller, Papers. Special Collections and University Archives, University of Illinois at Chicago

\section{$\underline{\text { Books }}$}

Addams, Jane. The Second Twenty Years at Hull-House. New York, NY: The MacMillan Company, 1930.

Addams, Jane. Twenty Years at Hull-House with Autobiographical Notes. New York, NY: The MacMillan Company, 1911.

Amberg, Mary Agnes. Madonna Center: Pioneer Catholic Settlement. Chicago, IL: Loyola University Press, 1976.

Breckinridge, Sophonisba P. New Homes for Old. New York, NY: Harper and Brothers, 1921.

Hanson, J.W., ed. The World's Congress of Religions: The Addresses and Papers Delivered Before the Parliament and an Abstract of the Congresses Held at the Art Institute. Washington, DC: W.B. Gonkey Company, 1893.

Hull House Maps and Papers. New York, NY: Thomas Y. Crowell \& Company, 1895.

Jones, Robert C. and Louis R. Wilson. The Mexican in Chicago. Chicago, IL: Chicago Congregational Union, 1931. 
Kelley, Francis C., ed. The First American Catholic Missionary Congress. Chicago, IL: J.S. Hyland and Company, 1908.

Official Report of the Second American Catholic Missionary Congress. Chicago, IL: J.S. Hyland \& Co., 1914.

Pacey, Lorene M., ed. Readings in the Development of Settlement Work. New York, NY: Association Press, 1950.

Park, Robert E. and Herbert A. Miller. Old World Traits Transplanted. New York, NY: Harper and Brothers Publishers, 1921.

Polachek, Hilda Satt. I Came a Stranger: The Story of a Hull-House Girl. Edited by Dena J. Polachek Epstein. Urbana, IL: University of Illinois Press, 1989.

Starr, Ellen Gates. On Art, Labor, and Religion. Edited by Mary Jo Deegan and AnaMaria Wahl. New Brunswick, NJ: Transaction Publishers. 2003.

Woods, Robert A. and Albert J. Kennedy. Handbook of Settlements. New York, NY: The Russell Sage Foundation, 1911.

Journal Articles

Addams, Jane. "The Housing Problem in Chicago." The Annals of the American Academy of Political and Social Sciences 20 (1902): 99-107.

“Chicago’s Housing Conditions.” The Charities Review 10, no. 7 (1900): 292-297.

Jones, Anita Edgar. "Mexican Colonies in Chicago." Social Services Review 2, no. 4 (Dec 1928): 579-597.

Starr, Ellen Gates. "Efforts to Standardize Chicago Restaurants-The Henrici Strike." The Survey 32 (1914): 214-215.

Walker, Natalie. "Chicago Housing Conditions. X. Greeks and Italians in the Neighborhood of Hull House.” American Journal of Sociology 21, no. 3 (1915): 285-316.

\section{Documents}

"Instructions of the Propaganda Fide Concerning Catholic Children in American Public Schools." 1875. In American Catholic History: A Documentary Reader, edited by Mark Massa and Catherine Osborne, 87-90. New York: New York University Press, 2017.

Kellor, Frances A. "Neighborhood Americanization: A Discussion of the Alien in a New Country and of the Native American in His Home Country." Address delivered at 
the Colony Club, New York, NY, February 8, 1918.

https://babel.hathitrust.org/cgi/pt?id=mdp.39015057101472\&view=1up\&seq=1

Leo XIII. Rerum Novarum. Maryknoll, NY: Orbis, 2010.

O'Brien, Robert Enlow. "A Study of the Roman Catholic Elementary Schools of Chicago.” PhD diss., Northwestern University, 1928.

"Rosa and the Chicago Commons: "How Can I Not Love America?"' In Immigrant

Women, edited by Maxine Schwartz Seller, 196-199. New York: State University of New York Press, 1994.

$\underline{\text { Newspapers and Periodicals }}$

The Catholic Charities Review

The Catholic Journal

The Chicago Tribune 


\section{Secondary Sources}

Abell, Aaron I. American Catholicism and Social Action: A Search for Social Justice 1865-1950. Garden City, NY: Hanover House, 1960.

Almgren, Gunnar, Susan P. Kemp, and Alison Eisinger. "Legacy of Hull House and the Children's Bureau in the American Mortality Transition." Social Service Review 74, no. 1 (March 2000): 1-27.

Arredondo, Gabriela F. Mexican Chicago: Race, Identity, and Nation, 1916-39. Urbana, IL: University of Illinois Press, 2008.

Arredondo, Gabriela F. "Navigating Ethno-Racial Currents: Mexicans in Chicago, 19191939.” Journal of Urban History 30, no. 3 (March 2004): 399-427.

Atkinson, Sue V. "Shifting Sands: Professional Advice to Mothers in the First Half of the Twentieth Century." Journal of Family History 42, no. 2 (2017): 128-146.

Badillo, David A. Latinos and the New Immigrant Church. Baltimore, MD: The Johns Hopkins University Press, 2006.

Barrett, James R., and David R. Roediger. "The Irish and the 'Americanization' of the 'New Immigrants' in the Streets and in the Churches of the Urban United States, 1900-1930." Journal of American Ethnic History 24, no. 4 (2005): 3-33.

Bochar, Jack. Locations of Chicago Roman Catholic Churches 1850-1990. Sugar Grove, IL: The Czech and Slovak American Genealogy Society of Illinois, 1997.

Brown, Dorothy M., and Elizabeth McKeown. The Poor Belong to Us: Catholic Charities and American Welfare. Cambridge, MA: Harvard University Press, 1997.

Brown, Linda Joyce. The Literature of Immigration and Racial Formation: Becoming White, Becoming Other, Becoming American in the Late Progressive Era. New York, NY: Routledge, 2004.

Brown, Mary Elizabeth. "The Making of Italian-American Catholics: Jesuit Work on the Lower East Side, New York, 1890-1950s.” Catholic Historical Review 73 (1987): 215-230.

Blum, Edward J. Reforging the White Republic: Race, Religion, and American Nationalism, 1865-1898. Baton Rouge, LA: Louisiana State University Press, 2005.

Burke, Kevin J., and Brian R. Gilbert. "Racing Tradition: Catholic Schooling and the Maintenance of Boundaries." Race Ethnicity and Education. 19, no. 3 (2016): 524-545. 
Carson, Mina. Settlement Folk: Social Thought and the American Settlement Movement, 1885-1930. Chicago, IL: The University of Chicago Press, 1990.

Cleary, James. "Catholic Participation in the World's Parliament of Religions, Chicago, 1893." Catholic Historical Review 55 no. 4 (Jan 1970): 585-609.

Cohen, Lizabeth. Making a New Deal: Industrial Workers in Chicago, 1919-1939. New York, NY: Cambridge University Press, 1990.

Cummings, Kathleen Sprows. New Women of the Old Faith: Gender and American Catholicism in the Progressive Era. Chapel Hill, NC: University of North Carolina Press, 2009.

Davis, Allen F. Spearheads for Reform: The Social Settlements and the Progressive Movement 1890-1914. New York, NY: Oxford University Press, 1967.

Davis, Thomas. "New Directions in Catholic Historical Research: Saints in Social Work." Journal of Religious and Theological Information 16 no. 4 (2017): 141151.

Deegan, Mary Jo. Race, Hull-House, and the University of Chicago: A New Conscience Against Ancient Evils. Westport, CT: Praeger, 2002.

Evans, Christopher H. The Social Gospel in American Religion: A History. New York, NY: New York University Press, 2017.

Fair, Alexandra. "“The Mind has to Catch up on Sex:' Sexual Norms and Sex Education in the Hull House.” Paedagogica Historica 54, no. 3 (Jan 2018): 249-265.

Flanagan, Maureen A. Seeing with their Hearts: Chicago Women and the Vision of the Good City, 1871-1933. Princeton, NJ: Princeton University Press, 2002.

Funchion, Michael F. "Irish Chicago: Church, Homeland, Politics, and Class - The Shaping of an Ethnic Group, 1870-1900." In Ethnic Chicago, edited by Peter d'A Jones and Melvin G. Holli, 8-39. Grand Rapids, MI: William B. Eerdmans Publishing Company, 1981.

Gabaccia, Donna R. "Emancipation and Exploitation in Immigrant Women's Lives." In The Oxford Handbook of American Immigration and Ethnicity, edited by Ronald H. Bayor, 107-123: New York, NY: Oxford University Press, 2016.

Galvin, Margaret A. "The Growth and Development of Madonna Center, a Catholic Social Settlement.” Master's thesis, Loyola University, 1951.

Ganz, Cheryl R. and Margaret Strobel, eds. Pots of Promise: Mexicans and Pottery at Hull House, 1920-40. Chicago, IL: University of Illinois Press, 2004. 
Garb, Margaret. "Health, Morality, and Housing: The 'Tenement Problem' in Chicago." American Journal of Public Health. 93, no. 9 (2003): 1420-1430.

Gleason, Phillip and David Salvaterra. "Ethnicity, Immigration, and American Catholic History." Social Thought, 3 (1978): 3-28.

Goodwin, Joanne L. Gender and the Politics of Welfare Reform: Mothers' Pensions in Chicago, 1911-1929. Chicago, IL: The University of Chicago Press, 1997.

Grossman, James R. "Southern Blacks' Migration to Chicago in the Early Twentieth Century." In Major Problems in American Urban and Suburban History, edited by Howard P. Chudacoff and Peter C. Baldwin, 251-260. Boston, MA: Houghton Mifflin Company, 2005.

Guglielmo, Thomas A. White on Arrival: Italians, Race, Color, and Power in Chicago, 1890-1945. New York, NY: Oxford University Press, 2003.

Haslett, Diane C. "Hull House and the Birth Control Movement: An Untold Story." Affilia Journal of Women and Social Work 12, no. 3 (Sept 1997).

Hess-Biber, Sharlene. "The Ethnic Ghetto as Private Welfare: A Case Study of Southern Italian Immigration to the United States 1880-1914." Urban and Social Change Review 12, no. 2 (Summer 1979): 9-15.

Hirsch, Susan E. "Ethnic and Civic Leadership in the Progressive Era: Charles H. Wacker and Chicago." Journal of American Ethnic History. 35, no. 4 (Summer 2016): 531 .

Holli, Melvin G., and Peter d'A Jones., eds. The Ethnic Frontier: Essays in the History of Group Survival in Chicago and the Midwest. Grand Rapids, MI: William B. Eerdman's Publishing Company, 1977.

Hoy, Suellen. “Caring for Chicago's Women and Girls: The Sisters of the Good Shepherd, 1859-1911.” Journal of Urban History 23, no. 3 (March 1997): 260294.

Hoy, Suellen. Ellen Gates Starr: Her Later Years. Chicago, IL: Chicago History Museum, 2010.

Ignatiev, Noel. How the Irish Became White. New York, NY: Routledge, 1995.

Innis-Jiménez, Michael. Steel Barrio: The Great Mexican Migration to South Chicago, 1915-1940. New York, NY: New York University Press, 2013.

Irving, Katrina. Immigrant Mothers: Narratives of Race and Maternity, 1890-1925. Champaign, IL: University of Illinois Press, 2000. 
Jackson, Shannon. Lines of Activity: Performance, Historiography, Hull-House Domesticity. Ann Arbor, MI: The University of Michigan Press, 2000.

Jacobson, Matthew Frye. Whiteness of a Different Color: European Immigrants and the Alchemy of Race. Cambridge, MA: Harvard University Press, 1999.

Kantowicz, Edward R. "Cardinal Mundelein of Chicago and the Shaping of TwentiethCentury American Catholicism." The Journal of American History 68, no. 1 (June 1981): 52-68.

Kantowicz, Edward R. Polish-American Politics in Chicago 1888-1940. Chicago, IL: The University of Chicago Press, 1975.

Kelleher, Patricia. "Young Irish Workers: Class Implications of Men's and Women's Experiences in Gilded-Age Chicago.” Eire-Ireland: A Journal of Irish Studies 36, no. 1 (2001): 141-165.

Lasch-Quinn, Elisabeth. Black Neighbors: Race and the Limits of Reform in the American Settlement House Movement, 1890-1945. Chapel Hill, NC: University of North Carolina Press, 1993.

Leavitt, Sarah A. From Catherine Beecher to Martha Stewart: A Cultural History of Domestic Advice. Chapel Hill, NC: University of North Carolina Press, 2002.

Lindley, Susan Hill. "You Have Stept Out of Your Place”: A History of Women and Religion in America. Louisville, KY: Westminster John Knox Press, 1996.

Linkh, Richard M. American Catholicism and European Immigrants, 1900-1924. Staten Island, NY: Center for Migration Studies, 1975.

Liptak, Dolores, ed. A Church of Many Cultures: Selected Historical Essays on Ethnic American Catholicism. New York, NY: Garland Publishing Inc., 1998.

Lissak, Rivka Shpak. Pluralism \& Progressives: Hull House and the New Immigrants, 1890-1919. Chicago, IL: University of Chicago Press, 1989.

McCaffrey, Lawrence J. “The Irish American Dimension.” In The Irish in Chicago, edited by Lawrence J. McCaffrey, Ellen Skerrett, Michael F. Funchion, and Charles Fanning, 1-21. Champaign, IL: University of Illinois Press, 1987.

McGreevy, John T. Parish Boundaries: The Catholic Encounter with Race in the Twentieth-Century Urban North. Chicago, IL: University of Chicago Press, 1996.

McGuinness, Margaret M. "Body and Soul: Catholic Social Settlements and Immigration.” US Catholic Historian 13, no. 3 (Summer 1995): 63-75.

Moloney, Deirdre M. American Catholic Lay Groups and Transatlantic Social Reform in the Progressive Era. Chapel Hill, NC: University of North Carolina, 2002. 
Muncy, Robyn. Creating a Female Dominion in American Reform 1890-1935. New York, NY: Oxford University Press, 1991.

Neary, Timothy. "Black-Belt Catholic Space: African-American Parishes in Interwar Chicago." U.S. Catholic Historian 18, no. 4 (Fall 2000): 76-91.

Nelli, Humbert S. Italians in Chicago 1880-1930: A Study in Ethnic Mobility. New York, NY: Oxford University Press, 1970.

Pacyga, Dominic A. Chicago: A Biography. Chicago, IL: University of Chicago Press, 2009.

Polachek, Hilda Satt. I Came a Stranger: The Story of a Hull-House Girl. Urbana, IL: University of Illinois Press, 1989.

Radziłowski, John. The Eagle and the Cross: A History of the Polish Roman Catholic Union of America, 1873-2000. New York, NY: Columbia University Press, 2003.

Reed, Christopher Robert. "The Early African American Settlement of Chicago, 18331870.” Journal of the Illinois State Historical Society 108, no. 4 (Fall/Winter 2015): 211-265.

Robinson, Stephanie Nicole. History of Immigrant Female Students in Chicago Public Schools, 1900-1950. New York, NY: Peter Lang Publishing, Inc., 2004.

Sánchez, George J. “'Go After the Women:’ Americanization and the Mexican Immigrant Woman, 1915-1929." In Unequal Sisters: A Multicultural Reader in U.S. Women's History, edited by Vicki L. Ruiz and Ellen Carol DuBois, 284-295. New York, NY: Routledge, 1994.

Seigfried, Charlene Haddock. "Socializing Democracy: Jane Addams and John Dewey." Philosophy of the Social Sciences 29, no. 2 (June 1999): 207-230.

Shanabruch, Charles. Chicago's Catholics: The Evolution of an American Identity. Notre Dame, IN: University of Notre Dame Press, 1981.

Skerrett, Ellen. “The Irish of Chicago's Hull House Neighborhood." In New Perspectives on the Irish Diaspora, edited by Charles Fanning, 189-222. Carbondale, IL: Southern Illinois University Press, 2000.

Skerrett, Ellen, Edward R. Kantowicz, and Steven M. Avella. Catholicism, Chicago Style. Chicago, IL: Loyola University Press, 1993.

Sklar, Kathryn Kish. "Who Funded Hull House?” In Lady Bountiful Revisited: Women, Philanthropy, and Power, edited by Kathleen D. McCarthy, 94-115. New Brunswick, NJ: Rutgers University Press, 1990. 
Skok, Deborah A. "The Historiography of Catholic Laywomen and Progressive Era Reform." U.S. Catholic Historian 26, no. 1 (Winter 2008): 1-22.

Skok, Deborah A. More than Neighbors: Catholic Settlements and Day Nurseries in Chicago, 1893-1930. Dekalb, IL: Northern Illinois University Press, 2007.

Spratt, Margaret. "Beyond Hull House: New Interpretations of the Settlement House Movement in America.” Journal of Urban History 23, no. 6 (September 1997): 770 .

Stebner, Eleanor J. The Women of Hull House: A Study in Spirituality, Vocation, and Friendship. New York, NY: State University of New York Press, 1997.

Tentler, Leslie Woodcock. Catholics and Contraception: An American History. Ithaca, NY: Cornell University Press, 2004.

Trolander, Judith. Professionalism and Social Change: From the Settlement House Movement to Neighborhood Centers 1886 to the Present. New York, NY: Columbia University Press, 1987.

Trolander, Judith. Settlement Houses and the Great Depression. Detroit, MI: Wayne State University Press, 1975. 